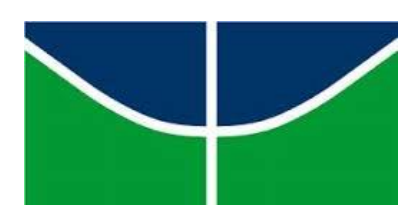

UNIVERSIDADE DE BRASÍLIA - UnB

FACULDADE DE ECONOMIA, ADMINISTRAÇÃO, CONTABILIDADE E GESTÃO PÚBLICA - FACE

PROGRAMA DE PÓS-GRADUAÇÃO EM ADMINISTRAÇÃO - PPGA

MESTRADO PROFISSIONAL EM ADMINISTRAÇÃO PÚBLICA

MARIANNE DANTAS FARIAS VIEIRA

APURAÇÃO E REEMBOLSO DO CUSTO DO PROCESSO DE TOMADA DE CONTAS ESPECIAL: ESTUDO DE CASO NO FUNDO NACIONAL DE SAÚDE

BRASÍLIA-DF

2016 
APURAÇÃO E REEMBOLSO DO CUSTO DO PROCESSO DE TOMADA DE CONTAS ESPECIAL: ESTUDO DE CASO NO FUNDO NACIONAL DE SAÚDE

Dissertação apresentada ao Programa de PósGraduação em Administração (PPGA) da Faculdade de Economia, Administração e Contabilidade (FACE) da Universidade de Brasília (UnB) como requisito parcial à obtenção do título de Mestre em Administração Pública.

Orientador: Prof. Dr. João Henrique Pederiva 


\section{APURAÇÃO E REEMBOLSO DO CUSTO DO PROCESSO DE TOMADA DE CONTAS ESPECIAL: ESTUDO DE CASO NO FUNDO NACIONAL DE SAÚDE}

Dissertação apresentada ao Programa de Pós-Graduação em Administração (PPGA) da Faculdade de Economia, Administração e Contabilidade (FACE) da Universidade de Brasília (UnB) como requisito parcial à obtenção do título de Mestre em Administração Pública. Aprovada em de de 2016 pela a banca examinadora:

Prof. Dr. João Henrique Pederiva, Orientador

Programa de Pós-Graduação em Administração - Universidade de Brasília

Prof. Dr. Valmir Emil Hoffmann, Membro Interno

Programa de Pós-Graduação em Administração - Universidade de Brasília

Prof. Dr. César Augusto Tibúrcio Silva, Membro Externo

Departamento de Ciências Contábeis e Atuariais - Universidade de Brasília

Prof. Dr. Ricardo Corrêa Gomes, Suplente

Programa de Pós-Graduação em Administração - Universidade de Brasília 
Dedico este trabalho a Ivo, meu marido, amor, amigo, companheiro, que me incentivou, ajudou, motivou e possibilitou a realização desse sonho, ficando ao meu lado em todos os 


\section{AGRADECIMENTOS}

Meus sinceros agradecimentos...

A Deus, por tudo.

Ao meu amado marido, companheiro e amigo, Alberto Ivo da Costa Vieira, pelo apoio incondicional, o carinho e amor, estando ao meu lado realizando sonhos e desejos, e superando decepções e frustrações. Sua compreensão e paciência foram fundamentais para essa etapa da minha vida.

Aos meu pais, Nilza Maria Dantas Farias e José Edmar Leal Farias, pela educação, carinho, amor, apoio e oportunidades para o crescimento pessoal e profissional.

Aos meus irmãos, Luciana Dantas Farias de Andrade e Natanael Dantas Farias, pelos momentos felizes e pelo companheirismo durante o crescimento, com especial agradecimento a minha irmã pelas dicas valiosas que contribuíram para a elaboração desse trabalho.

Aos meus avós, Nilo (in memorian) e Evanisa (in memorian), que em vida foram exemplo de humildade e gratidão, e a Demétrio e Bernadete, que são exemplos de amor e companheirismo e que me ensinam a enfrentar a vida com superação.

Ao meu sobrinho Isaac e afilhado Pedro, pelos momentos de alegria e descontração.

Aos meus tios, primos, sobrinhos, sogro, sogra, cunhadas e cunhado, pela oportunidade de conviver em um ambiente de amor familiar, que se traduzem em momentos de imensa alegria.

Ao meu orientador Prof. Dr. João Henrique Pederiva, por tudo o que me ensinou, incentivando constantemente a continuar fazendo sempre o meu melhor.

Aos professores Dr. Valmir Emil Hoffmann e Dr. César Augusto Tibúrcio Silva, por aceitarem participar da banca e pelas valiosas contribuições e ensinamentos. 
À turma do Mestrado Profissional em Administração Pública 2014.2 UnB-MS - Dayse, June, Alice, Del, Carol, Mônica, Cris, Larissa, Israel, Victor, Alexandre, Rodrigo Costa, Rodrigo Fávero, Diego, Domingos - pela ajuda, apoio e amizade que construímos.

Aos entrevistados, pelo tempo dedicado e as contribuições.

Ao Fundo Nacional de Saúde, pelo apoio e aprendizado diário.

A todos os professores que participaram da minha jornada acadêmica, pelos ensinamentos que foram transmitidos, que formaram a minha base de conhecimento e que foram essenciais para que eu pudesse chegar até aqui. 
O que vale na vida não é o ponto de partida e sim a caminhada. Caminhando e semeando, no fim terás o que colher. 


\section{RESUMO}

O trabalho teve como objetivo identificar como ressarcir a Administração Pública do custo do processo da TCE, alinhado ao Sistema de Informações de Custos do Governo Federal (SIC). Nesse estudo de caso do Fundo Nacional de Saúde, foi utilizado para apuração do custo do processo o método de custeio time-driven activity-based-cost (TDABC). Buscou-se como objetivos específicos mapear as atividades do processo em estudo, para viabilizar a apuração, por intermédio do método de custeio escolhido, sugerindo adaptação ao Sistema de Informações e Custos do Governo Federal (SIC), para enfim propor meios que contribuam para a Administração Pública obter o reembolso do valor gasto nos processos. O tipo de pesquisa foi descritiva e qualitativa, tendo os dados sido obtidos por meio de entrevista, registro de tempo e análise de documentos. A técnica de análise de dados utilizada foi a que preceitua o método de custeio TDABC e análise de conteúdo. Quanto aos resultados encontrados, constatou-se que o mapeamento de processo já existente no FNS não atende para aplicação do TDABC, tendo sido elaborado um mapeamento específico, em que viabilizou a aplicação do método que se chegou ao custo de $\mathrm{R} \$ 1,32$ por minuto, totalizando $\mathrm{R} \$ 2.616,39$, pelo menos, o valor médio do custo do processo de TCE. Essa apuração desconsidera alguns gastos, devido às limitações na obtenção e no processamento dos dados, e os custos incorridos em algumas etapas da TCE. Foram 105 as TCEs remetidas ao TCU, em 2016', valor estimado em R\$ 274.720,79. O acumulado de 2002 a 2015 totaliza 5.366 TCEs, equivalente ao custo de R\$ 14.039.540,74 apenas no caso examinado. Em relação à adaptação do SIC, ficou constatado que ainda não há meios de apuração do valor do custo do processo por meio desse sistema, sendo necessário que o órgão adote meios que refine a informação lançada nos sistemas estruturantes, para que seja possível a apuração a longo prazo. No tocante ao reembolso, a maioria dos entrevistados consideraram pertinente a cobrança do custo do processo de TCE aos responsáveis, desde que tenha uma legislação prevendo a cobrança, sendo uma das sugestões desse trabalho.

Palavras-Chaves: Tomada de Contas Especial. Sistema de Informações de Custos do Governo Federal. Reembolso. Time-driven activity-based-cost. Custos no setor público.

\footnotetext{
${ }^{1}$ Atualizado em 31/03/2016
} 


\begin{abstract}
The purpose of this study was to identify how to compensate the Public Administration for the cost of the Special setting of accounts (TCE) process, in line with the Federal Government Information System (SIC). In this case study of the National Health Fund, the time-driven activity-cost-costing method (TDABC) was used to calculate the cost of the process. The specific objectives were to map the activities of the process under study, to make feasible the calculation, through the chosen costing method, suggesting adaptation to the Information System and Costs of the Federal Government (SIC), in order to propose means that contribute to the Public Administration obtain the reimbursement of the amount spent on the processes. The type of research was descriptive and qualitative, having the data obtained through interview, time recording and document analysis. The data analysis technique used was the TDABC costing method and content analysis. Regarding the results found, it was verified that the process mapping already existent in the FNS does not respond to the application of TDABC, and a specific mapping was elaborated, in which it was possible to apply the method that arrived at the cost of $R \$ 1.32$ per Minute, totaling at least $R \$ 2,616.39$, the average cost of the TCE process. This calculation disregards some expenses, due to the limitations in obtaining and processing the data, and the costs incurred in some stages of the TCE. There were 105 TCEs sent to the TCU in 2016, with an estimated cost of R \$274,720.79. The accumulated from 2002 to 2015 totals 5,366 TCEs, equivalent to the cost of $\mathrm{R} \$ 14,039,540.74$ in the case under examination. In relation to the adaptation of the SIC, it was verified that there is still no means to calculate the cost of the process through this system, and it is necessary that the public agency adopts means that refine the information released in the structuring systems, so that it is possible to long term. With regard to reimbursement, most of the interviewees considered it appropriate to charge the cost of the TCE process to those responsible, as long as it has legislation foreseeing the collection, being one of the suggestions of this work.
\end{abstract}

Keywords: Special setting of accounts. System of costs of the federal government. Reimbursement. Time-driven activity-based-cost. Costs in the public sector. 


\section{LISTA DE FIGURAS}

Figura 1 - Órgãos envolvidos no processo de TCE, com início no Ministério da Saúde .......51

Figura 2 - Organograma da estrutura hierárquica regimental em que está inserido o FNS....54

Figura 3 - Estrutura da Coordenação de Contabilidade .......................................................56

Figura 4 - Mapeamento do processo de TCE na CCONT/FNS.......................................... 73

Figura 5 - Fluxo do Modelo TDABC para o processo de TCE ............................................. 78

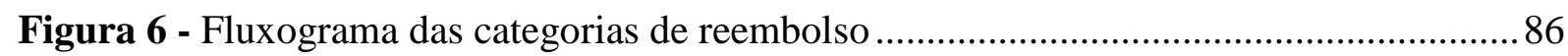




\section{LISTA DE TABELAS}

Tabela 1 - Dados dos quantitativos e valores das TCEs de 2016 e acumulado 2002-2015 ....50

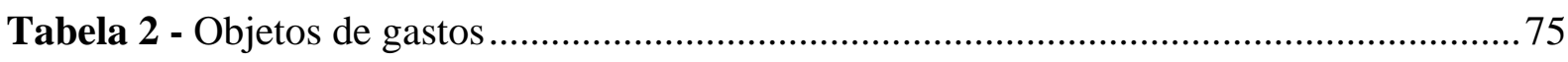

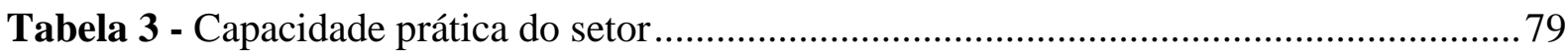

Tabela 4 - Taxa do custo da capacidade do setor por minuto................................................. 80

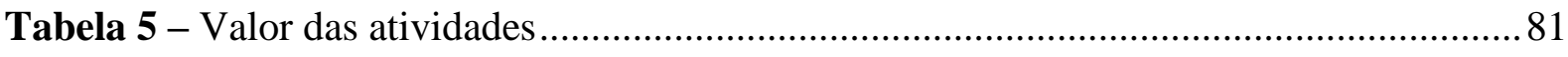

Tabela 6 - Categorias e subcategorias com maior impacto relacionadas ao SIC ...................83

Tabela 7 - Categorias e subcategorias com maior impacto referente ao reembolso................87 


\section{LISTA DE QUADROS}

Quadro 1 - Vantagens e desvantagens dos métodos de custeio 35

Quadro 2 - Seleção de tomadas de decisões disponíveis ao TCU no processo de TCE......... 38

Quadro 3 - Principais características do Sistema de Informações de Custos do Governo Federal .47

Quadro 4 - Fases da instauração da TCE no FNS/MS ...........................................................52

Quadro 5 - Técnicas de coleta de dados referente ao objetivo específico $\mathrm{n}^{\circ} 01$....................59

Quadro 6 - Técnicas de coleta de dados referente ao objetivo específico $\mathrm{n}^{\mathrm{o}} 02$.....................61

Quadro 7 - Entrevista referente ao objetivo específico $n^{\circ} 03$..............................................62

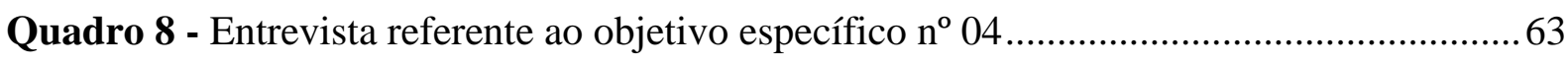

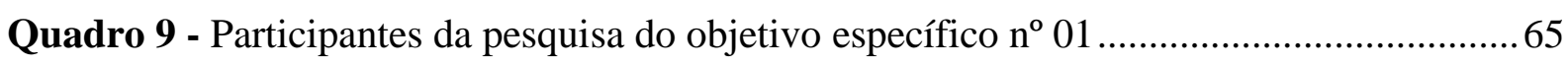

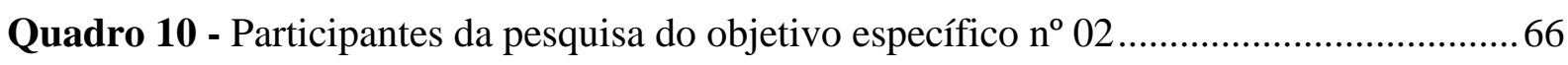

Quadro 11 - Participantes da pesquisa do objetivo específico $\mathrm{n}^{\mathrm{o}} 03$.....................................67

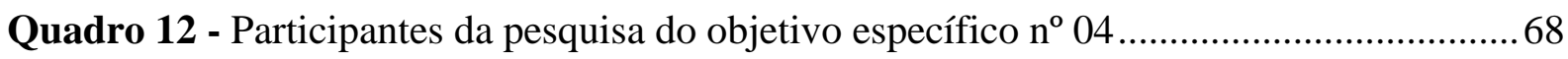

Quadro 13 - Categorias correlacionadas aos objetivos específicos......................................69

Quadro 14 - Quadro resumo da metodologia de estudo........................................................ 71

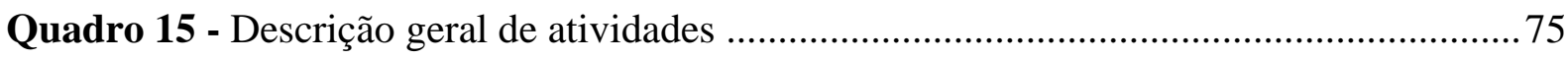




\section{LISTA DE ABREVIATURAS E SIGLAS}

\begin{tabular}{|c|c|}
\hline $\mathrm{ABC}$ & Custeio Baseado em Atividade (Activity Based Costing) \\
\hline $\mathrm{AGU}$ & Advocacia Geral da União \\
\hline APG & Administração Pública Gerencial \\
\hline CADIN & Cadastro Informativo de Créditos Não Quitados do Setor Público Federal \\
\hline $\mathrm{CCF}$ & Custo da Capacidade Fornecida do Departamento \\
\hline CCONT & Coordenação de Contabilidade \\
\hline CCONT/FNS & Coordenação de Contabilidade do Fundo Nacional de Saúde \\
\hline $\mathrm{CFC}$ & Conselho Federal de Contabilidade \\
\hline CGU & Controladoria-Geral da União \\
\hline CLP & Comissão de Legislação Participativa \\
\hline COTCE & Coordenação de Tomada de Contas Especial \\
\hline COTCE/FNDE & $\begin{array}{l}\text { Coordenação de Tomada de Contas Especial do Fundo Nacional de } \\
\text { Desenvolvimento da Educação }\end{array}$ \\
\hline CPRF & Capacidade Prática dos Recursos Fornecidos \\
\hline DICON & Divisão de Convênio \\
\hline DITCE & Divisão de Tomada de Contas Especial \\
\hline DRGs & Diagnosis Related Groups \\
\hline FASB & Financial Accounting Standards Board \\
\hline FMI & Fundo Monetário Internacional \\
\hline FNDE & Fundo Nacional de Desenvolvimento da Educação \\
\hline FNS & Fundo Nacional de Saúde \\
\hline HCFA & Health Care Financing Administration \\
\hline LRF & Lei de Responsabilidade Fiscal \\
\hline MEC & Ministério da Educação \\
\hline MS & Ministério da Saúde \\
\hline MP & Ministério Público \\
\hline NPM & New Public Management \\
\hline OCDE & Organização de Cooperação e de Desenvolvimento Econômico \\
\hline PIB & Produto Interno Bruto \\
\hline SAA & Secretaria de Assuntos Administrativos \\
\hline $\mathrm{SCF}$ & Sistema de Contabilidade Federal \\
\hline SERPRO & Serviço Federal de Processamento de Dados \\
\hline SETCE & Serviço de Tomada de Contas Especial \\
\hline SFFAS & Statement of Federal Financial Accounting Standards \\
\hline SIAFI & Sistema Integrado de Administração Financeira do Governo Federal \\
\hline SIAPE & Sistema Integrado de Administração de Recursos Humanos \\
\hline SIC & Sistema de Informações de Custos do Governo Federal \\
\hline SiGPC & Sistema de Gestão de Prestação de Contas \\
\hline SIGPLAN & Sistema de Informações Gerenciais e de Planejamento \\
\hline SIOP & Sistema Integrado de Planejamento e Orçamento \\
\hline SIORG & Sistema de Informações Organizacionais do Governo Federal \\
\hline
\end{tabular}


SISTCE

STN

SUS

TCC

TCE

TCU

TDABC

TG
Sistema de Tomada de Contas Especial

Secretaria do Tesouro Nacional

Sistema Único de Saúde

Taxa do Custo de Capacidade

Tomada de Contas Especial

Tribunal de Contas da União

Time-Driven Activity-Based Costing

Tesouro Gerencial 


\section{SUMÁRIO}

1. INTRODUÇÃO ........................................................................................................................16

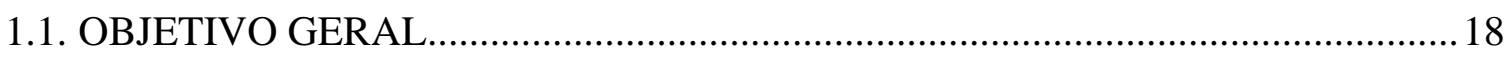

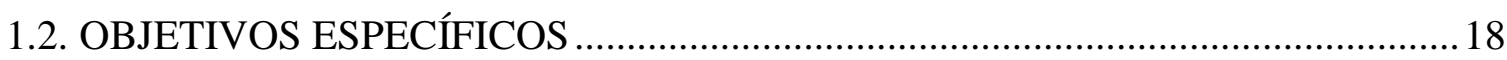

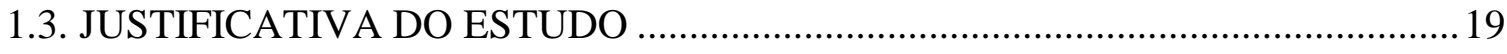

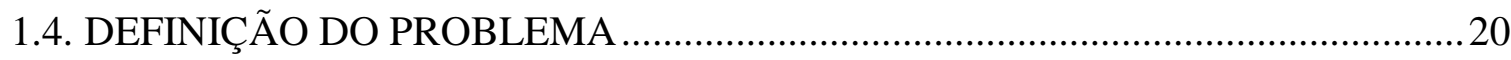

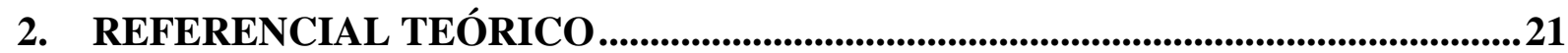

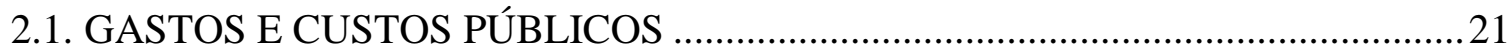

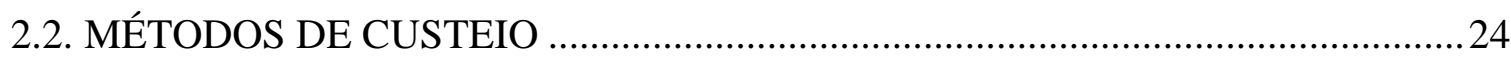

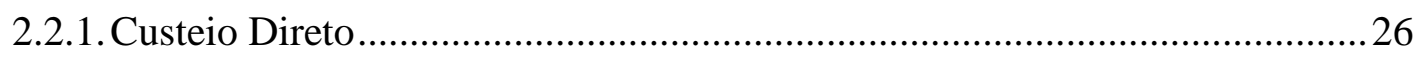

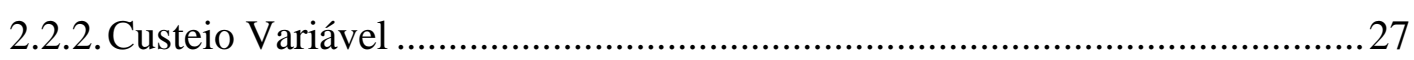

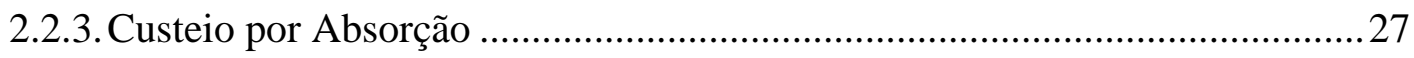

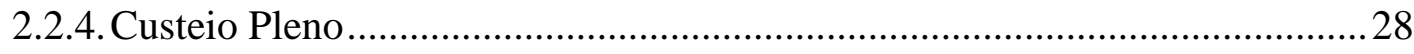

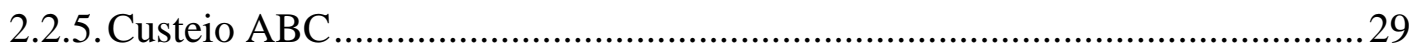

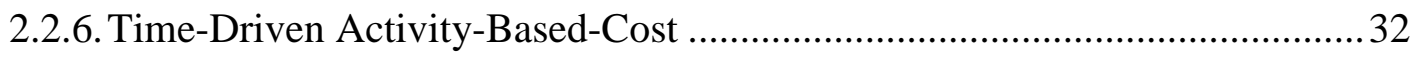

2.3. TOMADA DE CONTAS ESPECIAL …………………………………………….... 36

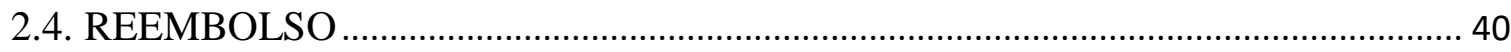

2.5. SISTEMA DE INFORMAÇÕES DE CUSTOS DO GOVERNO FEDERAL (SIC) 44

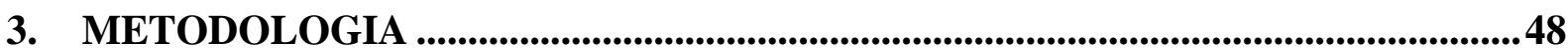

3.1. DESENHO E TIPIFICAÇÃO DA PESQUISA …………………………………..... 48

3.2. JUSTIFICATIVA DA ESCOLHA DO CASO ............................................................ 49

3.2.1. Órgãos envolvidos na Tomada de Contas Especial .......................................... 50

3.2.2. Fundo Nacional de Saúde............................................................................ 53

3.2.3. Escolha do método ……………………………………………………………..... 56

3.3. COLETA DE DADOS E CARACTERIZAÇÃO DOS INSTRUMENTOS DE

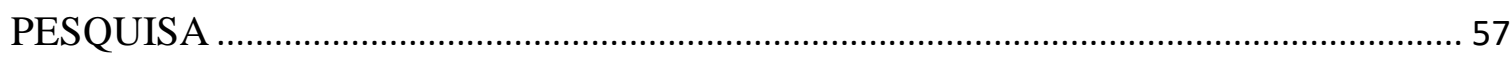

3.4. CARACTERIZAÇÃO DO PERFIL ESPERADO E PARTICIPANTES DA

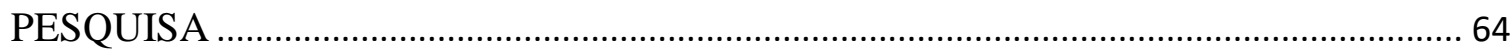

3.5. ANÁLISE E TRATAMENTO DOS DADOS ………………………………………..... 68

3.6. EXPECTATIVAS DE RESULTADOS ..................................................................... 70

4. DESCRIÇÃO E ANÁLISE DOS DADOS .................................................................72

4.1. MAPEAMENTO DO PROCESSO DE TCE NO FNS................................................ 72

4.2. APURAÇÃO DO CUSTO DO PROCESSO DE TCE PELO MODELO TDABC... 73 4.2.1. $1^{\circ}$ Passo: Identificação das Atividades Realizadas 
4.2.2. $2^{\circ}$ Passo: Realizar o Levantamento dos Objetos de Gastos do Setor 74

4.2.3.3 $3^{\circ}$ Passo: Estimativa da Capacidade Prática do Setor......................................... 78

4.2.4. $4^{\circ}$ Passo: Cálculo da Unidade de Tempo................................................................. 80

4.2.5. $5^{\circ}$ Passo: Estabelecimento da Unidade de Tempo Despendido em cada Atividade.

4.2.6. $6^{\circ}$ Passo: Cálculo do Processo de TCE................................................................ 82

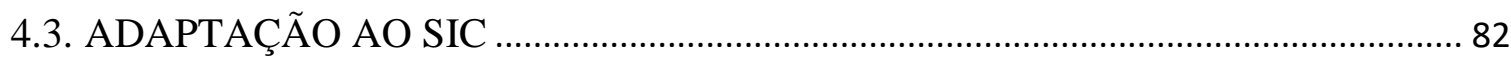

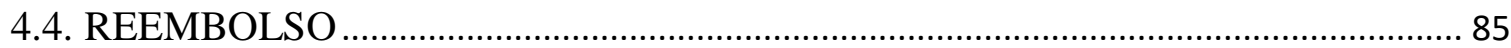

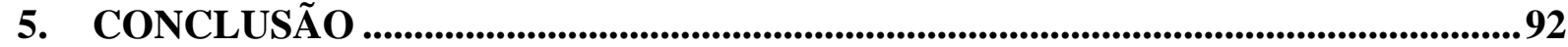

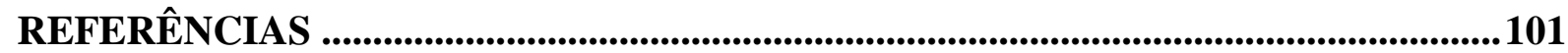

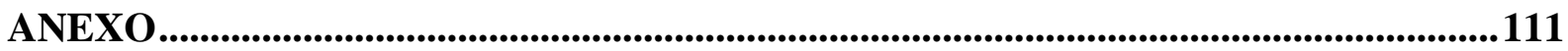

ANEXO A - Fluxograma do FNS ............................................................................111

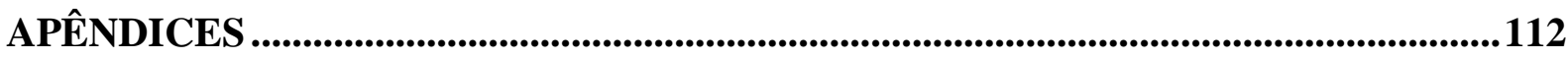

APÊNDICE A - Adequação dos roteiros semiestruturados para realização das

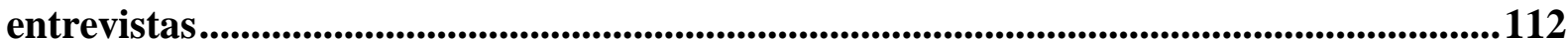

APÊNDICE B - Resultado da avaliação dos Roteiros de Entrevista ............................. 123

APÊNDICE C - Cálculo dos objetos de gastos do setor ..............................................133

APÊNDICE D - Categorias e subcategorias relacionadas ao SIC.....................................141

APÊNDICE E - Categorias e subcategorias referente ao reembolso ..............................142

APÊNDICE F - Expediente de encaminhamento de sugestão ............................................144 


\section{INTRODUÇÃO}

A experiência internacional mostra que há "uma forte relação entre as propostas de mudança na contabilidade do setor público e os movimentos de reforma da gestão pública que se intensificaram a partir dos anos 1980, sobretudo na linha do New Public Management" NPM (REZENDE; CUNHA; BEVILACQUA, 2010, p. 988). O NPM é um modelo normativo pós-burocrático que visa à reestruturação dos serviços governamentais com foco em gestão administrativa pública, ligado ao modelo gerencial ou à nova gestão pública (SECCHI, 2009).

A necessidade de ressarcimento de prejuízo ao erário decorrente de atos ilícitos, e está prevista na Constituição Federal. O reembolso desses e outros danos ao erário, às vezes, materializa-se em decorrência da Tomada de Contas Especial (TCE). Nesse sentido, o ressarcimento do custo das tomadas de contas especiais, no bojo do ressarcimento do dano que as ensejou, é o objeto de investigação desta pesquisa.

De acordo com o Statement of Federal Financial Accounting Standards (SFFAS) no 4, documento emitido pela Financial Accounting Standards Board (FASB) - órgão estadunidense responsável em editar e padronizar os procedimentos relacionados à contabilidade de empresas cotadas em bolsa e não governamentais - na gestão de programas do Governo Federal, informações de custo são essenciais para cinco áreas: 1) orçamento e controle de custos; 2) medição de desempenho; 3) determinação de ressarcimento, reembolsos e taxas, assim como ajuste dos preços; 4) avaliações do programa; e 5) tomada de decisão (FASB, 1995).

No que concerne à determinação do reembolso, é uma prática comum nos países europeus a utilização de sistemas de custeio para apuração dos custos dos serviços de saúde para posterior reembolso (SÁNCHEZ-MARTÍNEZ et al, 2006; VOGL, 2012). No Brasil, há uma prática de cobrança de valores diferenciados entre atendimento particular e de plano de saúde, sem a utilização de critérios de custeio para essa diferenciação (MAIA et al, 2009) e no 
que concerne à remuneração dos serviços do Sistema Único de Saúde (SUS), a Lei no 8.080, de 19 de setembro de 1990 (BRASIL, 1990a), observa apenas a relação econômico-financeira como critério para fixação dos valores.

No âmbito jurídico brasileiro, existe o estabelecimento de custas judiciais, que são valores a serem pagos em decorrência dos serviços jurisdicionais, estabelecido pela Lei $\mathrm{n}^{\circ} 9.289$ de 4 de julho de 1996 (BRASIL, 1996).

Para a apuração dos custos é necessário que a entidade observe, dentre os vários métodos de custeio existentes, o que melhor se adequa, observando as etapas existentes no processo de construção dos custos unitários, a partir da formação de custos nos respectivos departamentos (CFC, 2012). Portanto, a implantação de um mecanismo de apuração de custos deve ser sistemática, gradual e atenta aos objetivos organizacionais e com o foco na informação, evidenciando os critérios de transparência e controle (CFC, 2012).

Nesses moldes, foi criado o Sistema de Informações de Custos do Governo Federal (SIC), que foi construído com base em informações do Sistema de Administração Financeira (SIAFI) e informações físicas trazidas do Sistema de Informações gerenciais e de Planejamento (SIGPLAN) e do Sistema Integrado de Administração de Recursos Humanos (SIAPE), todos do âmbito Federal, tendo como objetivo subsidiar as decisões governamentais e organizacionais relacionadas à alocação do gasto público, buscando a eficiência (SILVA, 2011).

Seguindo essa linha, este estudo visa identificar meios de obtenção do reembolso para a Administração Pública do custo do processo da TCE, apurando o valor do custo do processo, utilizando o método de custeio TDABC, alinhado ao Sistema de Informações de Custos do Governo Federal (SIC). 
A TCE é um processo instaurado pela Administração Pública, em casos excepcionais, com o objetivo de apurar responsabilidade de agentes causadores de dano causado ao erário (FERNANDES, 2015)

O modelo de apuração de custos utilizado foi o Time-Driven Activity Based Costing (TDABC), que possibilita a atribuição dos custos dos recursos diretamente aos objetos de custo, valendo-se de um simples referencial simulando os processos de execução das atividades pertinentes. Esse é o método mais adequado para a realização dos objetivos desse trabalho, descritos a seguir.

\subsection{OBJETIVO GERAL}

Identificar meios de obtenção do reembolso para a Administração Pública do custo do processo da TCE.

\subsection{OBJETIVOS ESPECÍFICOS}

a. Mapear o processo de TCE, em estudo de caso no Fundo Nacional de Saúde (FNS);

b. Apurar o custo de processo de TCE, utilizando o método de custeio Time-Driven Activity-Based Costing (TDABC);

c. Sugerir adaptação ao Sistema de Informações de Custos do Governo Federal (SIC) para apuração do custo dos processos de TCE;

d. Propor meios que contribuam para a Administração Pública obter o reembolso do valor gasto nos processos de TCE. 


\subsection{JUSTIFICATIVA DO ESTUDO}

O atual sistema financeiro e orçamentário utilizado pelo Governo Federal, o SIAFI, não foi concebido para apurar custos públicos, e sim controlar a execução da despesa, sendo este o motivo pelo qual sua estrutura de dados não é capaz de informar acerca dos produtos e processos de trabalho dos órgãos do Governo. Essa limitação enseja a necessidade da existência de um sistema de custos, conforme observa Alonso (1999).

Para o atendimento a essa demanda foi criado o Sistema de Informações de Custos do Governo Federal (SIC), implantado desde 2009. Porém, apesar dele ter como finalidade a fixação de preços públicos (MACHADO e HOLANDA, 2010), ele não informa o valor do processo de TCE, para que seja viável a cobrança desse valor.

Em relação à TCE, conforme art. $2^{\circ}$ da IN nº 71 (BRASIL, 2012):

É um processo administrativo devidamente formalizado, com rito próprio, para apurar responsabilidade por ocorrência de dano à Administração Pública Federal, com apuração de fatos, quantificação do dano, identificação dos responsáveis e obter o respectivo ressarcimento.

A relevância da apuração do custo do processo de TCE decorre do fato de ser instaurada pela Administração Pública como um meio extremo de ressarcimento de recursos decorrente de dano causado ao erário. A TCE é medida de exceção, adotada quando não se tem sucesso com outros meios de cobrança, conforme a IN no 71 do TCU.

O limite mínimo de valor para instauração da TCE e remessa para julgamento pelo TCU é de R \$ 75.000,00, valor atualizado e acumulado para um mesmo instrumento de apuração, segundo IN n ${ }^{\circ} 71$ do TCU (BRASIL, 2012).

O processo de instauração da TCE envolve diversos setores da Administração Pública, com diferentes atividades, desde a área técnica do órgão instaurador até a conclusão do processo 
pelo órgão julgador, o que demonstra a necessidade de providências para que não se torne antieconômico ao erário (FERNANDES, 2015).

\subsection{DEFINIÇÃO DO PROBLEMA}

A inexistência do meio de apuração desses custos é um dos fatores impeditivos para que exista a imputação desses valores a quem lhes deu causa. $\mathrm{Na}$ atual situação, os gastos com o processamento das TCEs são absorvidos pelo erário, em lugar de integrarem os danos a serem ressarcidos mediante devido processo legal.

Tal situação incentiva os eventuais responsáveis por danos ao erário a optarem pela litigiosidade, em lugar da composição desses danos, o que provoca uma alocação socialmente injusta e ineficiente dos limitados recursos públicos. A ausência de uma metodologia formalizada de apuração desses custos de TCE também impede que os controles interno e externo avaliem a eficiência dos serviços públicos, restando prejudicado um mecanismo mais refinado dos atos de gestão dos administradores públicos, alheios aos aspectos formais e legais (ALONSO, 1999). Nesse sentido, a adaptação do SIC para tal finalidade seria um avanço para que haja uma apuração constante dos custos dos processos de TCE.

Diante do exposto, pretende-se saber qual é o custo do processo de TCE e como obter o reembolso do custo desse processo, sendo este apurado por meio do SIC? 


\section{REFERENCIAL TEÓRICO}

Este capítulo apresenta-se dividido em cinco partes. Na primeira, são abordados os gastos e os custos públicos visando ao reembolso, como ocorre no Brasil e em outros países. Em seguida, apresentam-se os métodos de custeio utilizados como instrumentos de apuração de custos, com destaque para o TDABC, que é a metodologia escolhida para este estudo de caso. A terceira parte aborda o assunto de Tomada de Contas Especial, processo no qual se almeja obter a informação sobre o custo. Dando continuidade, a quarta parte versa uma breve descrição dos mecanismos de reembolso. A última seção cuida do SIC, tendo em vista que um dos objetivos específicos é adaptá-lo para o auxílio na apuração do custo do processo.

\subsection{GASTOS E CUSTOS PÚBLICOS}

No âmbito da Administração Pública, qualquer gestão de ativo, inclusive de gastos, exige controle e acompanhamento. Para Martins (2003, p. 19), o gasto refere-se à: “Compra de um produto ou serviço qualquer, que gera sacrifício financeiro para a entidade (desembolso), sacrifício esse representado por entrega ou promessa de entrega de ativos (normalmente dinheiro)"

Em relação ao custo, este é abrangido pelo conceito de gasto e, de acordo com Martins (2003, p. 17), "é relativo a um bem ou serviço utilizado na produção de outros bens ou serviços", como no caso da TCE, em que há a utilização da força de trabalho e consumo de materiais para realização do serviço de análise de processos e elaboração de relatórios.

Para Martins (2003, p. 17) “o custo é também um gasto, só que reconhecido como tal, isto é, como custo, no momento da utilização dos fatores de produção (bens e serviços) ", devendo ser registrado pelo setor público no momento em que há a realização da ação de 
reconhecimento da geração do bem ou serviço. Além disso, no momento do reconhecimento, há a necessidade de imputar esse custo ao resultado do ente público, caso não se obtenha a situação de valor a receber de quem deu causa a esse gasto (MARTINS, 2003).

À medida que os sistemas econômicos mundiais vão ficando mais complexos, há um reflexo no aumento dos gastos públicos ao longo do tempo, em decorrência da crescente atuação do governo. De acordo com Giambiagi e Além (2011, p. 10), “a percentagem dos gastos públicos sobre o Produto Interno Bruto (PIB) passou de uma média internacional, no grupo dos países mais desenvolvidos do mundo, de cerca de $11 \%$ no final do século XIX, para algo em torno de 46\% em 1996".

A partir de 1990, tendo em vista um crescente gasto público na área social por países com o mais alto nível de bem-estar, como a Suécia, Dinamarca e Alemanha, começou a haver um alerta das organizações internacionais, como o FMI, para evitar uma crise fiscal. A Suécia e a Dinamarca foram ativas na redução das despesas, que estava chegando a $60 \%$ do PIB, com impacto no crescimento econômico e na estabilidade financeira. Em 2005, as preocupações acerca dos gastos públicos na área social não ficaram restritas a apenas alguns países, mas sim a toda a Europa (BOSANQUET, 2012).

No âmbito dos países da Organização de Cooperação e de Desenvolvimento Econômico (OCDE), que é uma organização internacional composta por 34 países, no que concerne aos gastos e aos custos dos serviços de saúde, este aumentou $4 \%$ ao ano ao longo dos últimos dez anos, índice duas vezes maior que o crescimento PIB. Os fatores que podem ter contribuído para o aumento foram os custos de oportunidade do gasto público, dentro das economias nacionais, sem a contrapartida do aumento das receitas fiscais, tendo em vista que tal aumento levaria a perdas no consumo (BOSANQUET, 2012). 
Para a realidade brasileira, a exigência legal de utilização de um sistema de custos data de 1964 (SILVA, 2011). Com o advento da Constituição de 1988, que introduziu três princípios para a Administração Pública mais moderna, quais sejam a economicidade, a eficácia e a eficiência (este mais recente, com o advento da Emenda Constitucional n¹9/1998), e com os avanços da tecnologia foi possível dar início ao cumprimento da utilização de um sistema de custos (SILVA, 2011). Todavia, quase nenhum serviço prestado pela Administração Pública são mensurados, estando restritos aos que constam no orçamento, relacionados à área fim de cada órgão (SILVA, 2011).

O constante crescimento do Estado e dos gastos públicos representam um desafio para as sociedades modernas, que têm que operar com menores custos unitários e produzir melhores estruturas de Governo (REZENDE, 2008).

O aumento desses gastos públicos é reflexo de decisões tomadas pelo Governo e que envolve a "complexa interação entre o Estado e a sociedade" e que " resulta em diferentes padrões de gastos e de tributação que agregadamente tentam dar conta de preferências sociais por determinados bens e serviços públicos” (REZENDE, 2008, p. 611). Além disso, Thamae (2013) argumenta que o crescimento do nível de gastos do Governo depende também das mudanças nas condições sociais e de mercado.

Ademais, Rezende, Cunha e Bevilacqua (2010, p. 988) citam que as reformas administrativas, que visam à melhoria da gestão dos recursos públicos buscando maior eficiência, "ganharam força no contexto de preocupações com a necessidade de conter o crescimento dos gastos públicos, pois só assim seria possível reduzir a carga tributária com vistas a preservar a competitividade econômica no mercado global”. 
Larkin, Richardson e Tabreman (2012) defendem que a partilha de soluções de custos entre países pode ajudar a garantir que cortes de gastos públicos não se tornem uma barreira, mas sim um incentivo à produtividade.

Sob um ponto de vista gerencial, de acordo com Silva (2011), acredita-se que o sistema de custo tenha o poder de minimizar os traumas relacionados à quebra da administração patrimonialista e burocrática e o florescer da administração gerencial da eficiência, da eficácia e da efetividade das ações governamentais, demonstrando uma ligação com o foco em melhoria de desempenho preconizado pelo NPM.

A principal ideia econômica de reforma do Estado é encontrar um modo de utilizar o dinheiro público da melhor forma possível, com serviços de melhor qualidade a custos menores, com uso mais adequado das receitas dos impostos, pois este é um recurso escasso, tornando a organização do Estado mais eficiente e com melhor desempenho (BRESSER-PEREIRA, 2008).

A intenção é que as reformas administrativas atinjam os objetivos propostos, que geralmente estão ligados à melhoria do desempenho, como no caso do NPM, em que se busca a consciência por parte dos governos e cidadãos em relação a custos, à flexibilidade e à transparência, sempre voltada à satisfação do cliente que é o contribuinte (MATIAS-PEREIRA, 2008), e buscando aplicar os métodos utilizados pelo setor privado na área pública, executando práticas mais eficientes que favorecem um ambiente competitivo em busca de resultados (REZENDE, CUNHA e BEVILACQUA, 2010; ASHRAF e UDDIN, 2015).

\subsection{MÉTODOS DE CUSTEIO}

Método de custeio "se refere ao método de apropriação de custos e está associado ao processo de identificação e associação do custo ao objeto que está sendo custeado" (CFC, 2012 p. 48). São instrumentos utilizados pela contabilidade de custos e a escolha de um deles deve 
estar compatível com os objetivos e as características da entidade e do objeto de custos que se pretende avaliar, dependendo do tipo de informação necessária aos gestores (ABBAS, GONÇALVES e LEONCINE, 2012).

Cada autor defende o seu método, mas deve-se ter em mente que "nenhum dos métodos é perfeito e resolverá todos os problemas das organizações", conforme afirmam Abbas, Gonçalves e Leoncine (2012, p. 145), e para a escolha deve-se considerar o tipo de informação que se pretende obter e o método que, apesar de todos apresentarem vantagens e desvantagens, gere informações aos gestores, de acordo com o fim que se pretende obter (ABBAS, GONÇALVES e LEONCINE, 2012).

De acordo com o CFC (2012), as entidades têm a opção em utilizar mais de um método de custeio, conforme os objetos de custo, e esse método deve estar alinhado à disponibilidade das informações e aos recursos requisitados para se obter as informações ou os dados necessários.

Os objetivos do uso dos métodos de custeio são, de acordo com Abbas, Gonçalves e Leoncine (2012, p. 146):

Determinar o valor dos objetos de custeio; reduzir custos, melhorar os processos; eliminar desperdícios; decidir entre produzir ou terceirizar; e eliminar, criar e aumentar, ou diminuir, a linha de produção de certos produtos além da obtenção de outras informações que os gestores julgarem necessários.

Conforme CFC (2012), os principais métodos de custeio são: direto, variável, por absorção, por atividade e pleno, e a escolha do método de custeio do setor público não é fácil, considerando que há quem defenda cada um desses métodos, com os respectivos argumentos.

Portanto, para fundamentar esse estudo serão descritos sinteticamente alguns métodos de custeio com ênfase no TDABC, adotando a ordem de apresentação semelhante a disposta por CFC (2012), alterando apenas entre o método de custeio pleno pelo de por atividade, tendo 
em vista a conclusão com o método TDABC, que é método utilizado por esta pesquisa, e que, juntamente com o ABC, é um tipo de custeio por atividade. Sendo assim, a sequência de apresentação adotada é: direto, variável, por absorção, pleno e por atividades.

\subsubsection{Custeio Direto}

O método de Custeio Direto "é o custeio que aloca todos os custos - fixos e variáveis diretamente a todos os objetos de custo sem qualquer tipo de rateio ou apropriação" (CFC 2012, p. 48) ressaltando que esse método não sofre qualquer tipo de rateio. Machado (2002, p. 145) conceitua o custeio direto como:

Aquele que apropria os custos diretos, quer fixos, quer variáveis, a quaisquer objetos de custo, sejam eles produtos, lotes de produtos, centros de responsabilidade, centros de resultado, sejam quaisquer outros de interesse do gestor.

De acordo com Schoeps (1992), este método contribui tanto para alavancar a competitividade da empresa, quanto auxiliar no planejamento do resultado econômico e estipular preços, alinhado à capacidade instalada de produção e das condições de mercado.

As vantagens desse método, de acordo com Machado e Holanda (2010, p. 811-812), para o uso no setor público são:

O primeiro argumento, em defesa do custeio direto, é que esse método, por não conter qualquer tipo de rateio, permite analisar o desempenho dos gestores e das políticas públicas com maior objetividade e sem as intermináveis discussões a respeito dos custos gerais transferidos. E facilitar a análise de resultado e desempenho é o objetivo central do sistema integrado de custos.

O segundo argumento é que esse método está entranhado no sistema de planejamento, orçamento e contabilização da execução orçamentária, o que facilita a implantação do sistema integrado de custos (...)

O terceiro argumento é que a relação custo-benefício da informação, embora difícil de ser quantificada, é claramente favorável ao método do custeio direto, uma vez que sua implantação pode ser feita muito rapidamente com baixo custo de treinamento, já que para os funcionários e gestores esse método soa familiar. 
Em relação às desvantagens: a) não observa os avanços da gestão por atividades; e b) atribui valor a bens e serviços de forma arbitrária, podendo distorcer o valor final do produto (MACHADO e HOLANDA, 2010; ALONSO, 1999).

\subsubsection{Custeio Variável}

No Custeio Variável, “os produtos são mensurados somente com base nos custos variáveis, sejam eles diretos ou indiretos" (LEONE, PEDROSA e PAULO, 2014, p. 64). Dentro deste tipo de custeio, apenas os custos que variam de acordo com a produção é que são considerados como custo do produto ou inventariado, diferente dos custos fixos, que são diretamente atribuídos ao resultado do exercício (ABBAS, GONÇALVES e LEONCINE, 2012).

As principais vantagens desse método de custeio, conforme afirma Megliorini (2006) é o fato de auxiliar nas seguintes situações: a) na atribuição do valor de preço de venda, tendo em vista que ele estabelece um valor mínimo a ser praticado em relação aos custos; b) na tomada de decisão quanto ao uso de recursos limitados; c) na distinção entre os produtos mais rentáveis; e d) na tomada de decisão no que diz respeito a comprar ou produzir um determinado item.

Dentre as desvantagens, consideradas pelo mesmo autor, está o fato de não ser aceito pela auditoria externa das sociedades abertas, muito menos pela legislação fiscal, tendo em vista que fere os princípios fundamentais de contabilidade.

\subsubsection{Custeio por Absorção}

O Custeio por Absorção, segundo Martins (2003, p. 24), “é o método derivado da aplicação dos princípios de contabilidade geralmente aceitos (...)" e "consiste na apropriação de todos os custos de produção aos bens elaborados, e só os de produção; todos os gastos 
relativos ao esforço de produção são distribuídos para todos os produtos ou serviços feitos". De acordo com Megliorini (2006), o custeio por absorção foi estruturado para atender às disposições legais, tendo os custos fixos rateados aos produtos.

Para Megliorini (2006), Martins (2003) e Abbas, Gonçalves e Leoncine (2012), as principais vantagens desse método são: a) atende aos princípios contábeis; b) é o método aceito pela legislação fiscal; c) aloca os custos diretos e indiretos; e d) é menos custoso para implementar.

Já as desvantagens, para os mesmos autores são: a) tem um alto grau de arbitrariedade quanto aos critérios de rateio dos custos, tendo em vista que estes não se relacionam com bens ou serviços específicos; b) o custo fixo de uma unidade está diretamente relacionado ao volume de produção, e assim, o custo de um produto pode ser influenciado, e sofrer variações, em decorrência da alteração de volume de um outro produto; e c) não fornece informações gerenciais precisas, podendo induzir os gestores na tomada de decisão que podem gerar estoque ou avaliação de resultado equivocada.

O Tribunal de Contas da União (TCU) realizou a apuração do custo do processo de TCE, no âmbito daquele órgão, utilizando o método de custeio por absorção, que na época alcançou o valor de R \$ 100.167,87, conforme acórdão n 1631/2009 - Plenário (BRASIL, 2009).

\subsubsection{Custeio Pleno}

O método de Custeio Pleno, também conhecido como RKW, é aquele que leva aos objetos de custeio todos os custos e as despesas de uma entidade, sejam eles fixos ou variáveis, diretos ou indiretos (VARTANIAN e NASCIMENTO, 1999). De acordo com Martins (2003, p. 158), “(...) consiste no rateio não só dos custos de produção, como também de todas as despesas da empresa, inclusive financeiras, a todos os produtos". 
Para Vartanian e Nascimento (1999, p.7), a principal vantagem do custeio pleno “(...) é o fato de serem levados em conta todos os gastos ocorridos em uma organização, sem exceções. Isso resulta numa informação de custos unitário, completa e conservadora”. A desvantagem desse método é o fato de ferir os princípios contábeis e a arbitrariedade da apuração, podendo ser utilizada apenas para fins gerenciais (MARTINS, 2003).

Biazebete, Borinelli e Camacho (2009) frisam que esse método só pode ser utilizado para fins gerenciais, auxiliando na tomada de decisões relativas a preços e outras questões, não sendo utilizado pela contabilidade financeira.

\subsubsection{Custeio ABC}

O método de Custeio ABC levanta a hipótese de que os custos são gerados pelas atividades e como consequência, pela realização do mapeamento de processo de todas as atividades, fica mais evidente como os recursos são consumidos pela organização. Esse mapeamento revelará quais as atividades que adicionam e as que não adicionam valor ao produto, pois em cada atividade fica claro o quanto de recurso foi consumido (ALONSO, 1999; NAKAGAWA, 2001).

Portando, fica claro que os custos são provenientes das execuções das atividades, que ao se realizarem consomem os recursos, diferente dos outros métodos em que o objeto de custo é que serve como base de apropriação dos recursos (DIEHL, SOUZA e ALVES, 2008; NIVEIROS et al, 2013).

O conceito de atividade para Nakagawa (2001, p. 42) é:

Um processo que combina, de forma adequada, pessoas, tecnologias, materiais, métodos e seu ambiente, tendo como objetivo a produção de produtos. Em sentido mais amplo, entretanto a atividade não se refere apenas a processos de manufatura, mas também à produção de projetos, serviços etc., bem como às inúmeras ações de suporte a esses processos. Seria útil também caracterizarmos a atividade, reduzindo-a à sua forma mais simples: processamento de uma transação. 
De acordo com Monroy, Narisi e Peláez (2012), o método de custeio ABC cumpre as seguintes etapas: a) identificação das atividades; b) definição dos recursos para realizar as atividades; c) definição dos fatores que envolvem o custo das atividades; d) identificação dos direcionadores de custos; e) alocação da atividade por centro de custo; e f) o cálculo do custo unitário do produto ou serviço.

Quanto à aplicabilidade no setor público, em uma análise preliminar, Machado (2005) observa que não há maiores dificuldades em se implementar o custeio por atividades no setor público, tendo em vista que toda ação governamental é decomposta por atividades ou projetos, sendo estes os elementos principais nos sistemas de orçamento.

Além disso, Machado (2005) afirma que nada impede que determinados órgãos construam modelos específicos de análise e gerenciamento de custos baseados em um método de custeio por atividade, a partir das informações extraídas do sistema de informação contábilgerencial, e observados os requisitos do processo de implantação, treinamento e tempo de estabilização do sistema.

Alonso (1999) ressalta que esse método é utilizado pelos órgãos de governo, nos Estados Unidos, tais como a Receita Federal e as Forças Armadas, e entende que este é o método mais indicado a ser utilizado no setor público, diante do grande número de atividades complexas e variadas existentes, e que com esse método seria possível obter um melhor controle dos gastos.

O método de custeio $\mathrm{ABC}$ teve como grande impulsionador de desenvolvimento, de acordo com o entendimento de Megliorini (2006), Kaplan e Anderson (2004a), Alonso (1999) e Abbas, Gonçalves e Leoncine (2012), entre outros autores, a insatisfação com os dados de custos fornecidos por métodos de custeio tradicionais, que distorcem as informações acerca dos bens e serviços, atribuindo os custos indiretos aos produtos de maneira arbitrária. Eles entendem que os métodos tradicionais foram criados para uma época em que as despesas indiretas não 
tinham valores expressivos, a tecnologia era estável e que tinham como fatores de produção determinantes a mão de obra direta e os materiais de produção.

Dentre as vantagens desse método estão as mudanças nas bases de alocação de custos, em virtude da destinação dos custos de bens e serviços a partir das bases de atividades, além de auxiliar nas situações em que são necessárias reestruturações e aperfeiçoamentos no processo de trabalho (NAKAGAWA, 2001). Além disso, o ABC é uma poderosa ferramenta quando utilizada em programas que visam à reestruturação e à melhoria das práticas de gestão, considerando que ele não observa apenas os custos já incorridos, mas também auxilia na simulação dos impactos relacionados às ações de melhorias de processos. Ele possibilita, ainda, cortes específicos de despesas em programas de ajuste fiscal, diminuindo o impacto negativo que esses programas podem gerar (ALONSO, 1999).

Em relação às desvantagens, Megliorini (2006) cita o fato da semelhança desse método com o método de Custeio por Absorção no que concerne a não separação dos custos fixos, apropriando-os diretamente aos bens e serviços.

Para Kaplan e Anderson (2007) as desvantagens são: a) a fase de entrevistas e levantamento de dados é demorada e dispendiosa; b) os dados são subjetivos e de difícil validação; c) o processo de armazenamento e processamento dos dados é dispendiosa; d) por ser muito específico não demonstra uma visão geral em relação às oportunidades de lucro, nos diversos setores da empresa; e) é de difícil atualização e adaptação a novos fatores e circunstâncias; e f) não considera a capacidade ociosa, incorrendo em erro teórico.

Em relação a publicações envolvendo o método de Custeio $\mathrm{ABC}$, vale registrar que em um estudo bibliométrico realizado por Diehl, Souza e Alves (2008) foi observado que os trabalhos relacionados ao método de custeio $\mathrm{ABC}$ em periódicos e congressos têm sido eminentemente relacionados a relatos de aplicação de casos empíricos, além de que “(...) tem 
havido pouca contribuição teórica dos trabalhos, estando os mesmos essencialmente baseados no arcabouço teórico de livros textos e autores clássicos” (DIEHL, SOUZA e ALVES, 2008, p. 12).

\subsubsection{Time-Driven Activity-Based-Cost}

Diante de algumas desvantagens apresentadas pelo método $\mathrm{ABC}$, foi realizada uma simplificação do método de custeio com foco na apuração por atividades, sendo criado o TimeDriven Activity-Based Costing (TDABC) com a proposta de ser mais simples, pelo fato de exigir apenas dois conjuntos de estimativas: o tempo consumido para realizar as atividades relacionadas ao objeto de custo e o custo por unidade de tempo (KAPLAN e ANDERSON, 2007; PERNOT, ROODHOOFT e VAN DEN ABBEELE, 2007).

Portanto, o TDABC é uma derivação do método ABC. Segundo Pernot, Roodhooft e Van Den Abbeele (2007), o TDABC é um método em que os criadores Kaplan e Anderson, buscaram tornar a apuração dos custos menos onerosa financeiramente e mais fácil de ser executada, sem abrir mão dos benefícios oferecidos por um método de custeio baseado em atividades.

O TDABC pode ser considerado uma estratégia contábil e uma ferramenta para a eficiência, sendo usada pelos mais diversos tipos de organizações e também na área da saúde, para apuração de custos de tratamento dos pacientes (OKLU et al, 2015). Sendo assim, o TDABC auxilia as organizações a obter lucros e melhorias significativas, tendo em vista que esse método possibilita “(...) estimar diretamente a demanda de recursos gerada por transação, produto ou cliente" (KAPLAN e ANDERSON, 2004a, p. 132; KAPLAN e ANDERSON, 2003). 
Esse método é capaz de identificar a capacidade de cada departamento ou processo e alocar o custo desta capacidade nos diversos grupos de recursos alinhados ao objeto de custo, com base no tempo exigido para a execução de uma atividade (MONROY, NASIRI e PELÁEZ, 2012). Para isso, tem como requisito que seja feita uma identificação dos recursos necessários para executar as atividades, semelhante a uma abordagem tradicional, mas, diferente dos outros métodos, ela requer que seja identificada o tempo de realização das atividades, alinhado à capacidade teórica dos recursos disponíveis (DALCI, TANIS e KOSAN, 2010).

As 6 etapas que envolvem o método em discussão, de acordo com Everaert e Bruggeman (2007), Everaert et al (2008) e Silva et al (2011) são: a) identificação dos grupos de recursos e as atividades em que estão sendo realizadas; b) definição dos custos de cada grupo; c) estimativa da capacidade prática das atividades; d) cálculo da unidade de tempo; e) estabelecimento da unidade de tempo despendido em cada atividade; e f) cálculo do processo.

Em relação aos casos práticos, dentre os vários identificados durante a pesquisa, podese destacar o estudo desenvolvido por Pernot, Roodhooft e Van Den Abbeele (2007), que aplicaram o TDABC em uma universidade a fim de demonstrar a utilização do método em serviços interbibliotecas e que teve como resultado uma melhoria na gestão de custos de todos os serviços prestados, diante da possibilidade dos gestores tomarem medidas para a redução do tempo para as solicitações dos clientes da biblioteca.

Há também o estudo desenvolvido por Everaert et al (2008), que descreveram o fato da má alocação de $54 \%$ dos custos durante o uso do método de custeio $\mathrm{ABC}$ tradicional e que foi revelado ao aplicar o método TDABC. O estudo desenvolvido por Dalci, Tanis e Kosan (2010) avaliou o custo em um hotel na Turquia, aplicando o TDABC, e evidenciou que o método auxilia a gerência ao gerar informações que propiciam a aplicação de estratégias financeiras mais apropriadas e equilibradas entre os departamentos. 
O estudo de Oklu et al (2015) se remete a uma potencial aplicação do método de custeio TDABC em procedimentos intervencionistas realizados em hospitais, que demonstrou ser bastante satisfatório, considerando que, quando o TDABC é usado de uma maneira diversificada dentro da organização, a ênfase na variação dos custos pode definir caminhos diferentes para os mesmos serviços médicos, já que nem sempre é necessário adotar todos os procedimentos para o cumprimento das etapas do processo de atividades. Já no estudo de caso realizado por Demeere, Stouthuysen e Roodhooft (2009), que teve como foco a implementação do TDABC em cinco departamentos de um ambulatório, apresentou também um bom resultado ao proporcionar aos médicos e gestores da saúde valiosas informações, que subsidiaram melhorias operacionais e base para decisões relacionadas a futuros investimentos.

Além dos estudos citados, há uma Nota Técnica elaborada por Silva et al (2011) que se tornou referência para o desenvolvimento de trabalhos que utilizam o TDABC, pois tem como objetivo a aplicação deste método no Sistema Nacional de Emprego (SINE), unidade ligada ao Ministério do Trabalho e Emprego, evidenciando o cálculo dos custos dos serviços prestados por aquele órgão, assim como o cálculo da implantação e manutenção de outras unidades operacionais de atendimento, auxiliando na celebração dos convênios com o Ministério do Trabalho e Emprego.

Portanto, as vantagens advindas da aplicação do TDABC envolvem o fornecimento da capacidade em mensurar o custo em nível de atividades (REDDY, VENTER e OLIVIER, 2012; SCHMIDT, SANTOS e LEAL, 2009), a simplificação do modelo ABC e a facilidade em aplicação do método, dentre as já citadas.

As desvantagens apresentadas por Lee, Austin e Pronovost (2014), Souza et al (2012), Boina et al (2015) e Zambon e Zorzo (2014) são as seguintes: a) desconfiança nos resultados apresentados quando aplicados em organizações que não tenham métodos padronizados ou uma 
infraestrutura adequada para apurar os dados; b) dificuldade em elaborar as equações de tempo para atividades ou ambientes não estruturados; c) subjetividade nas estimativas de tempo de cada atividade individualmente; e d) exigência de um elevado volume de dados para estimar as equações de tempo.

No estudo bibliométrico realizado por Boina et al (2015, p. 168), foi identificado que, “apesar da difundida prevalência do TDABC, verifica-se escassez de estudos sobre esse método de custeio tanto em âmbito nacional quanto internacionalmente". Catânio, Pizzo e Moraes (2015) e Zambon e Zorzo (2014) corroboram com os dados e afirmam que grande parte dos estudos são empíricos, com predominância em estudos de caso, fato semelhante ao que tem acontecido no método de Custeio $\mathrm{ABC}$ e em convergência com os objetivos desta pesquisa.

Diante do exposto, foi consolidada, conforme Quadro 1, as informações acerca das principais vantagens e desvantagens dos métodos de custeio abordados.

Quadro 1 - Vantagens e desvantagens dos métodos de custeio

(Continua)

\begin{tabular}{|c|c|c|c|}
\hline MÉTODO & VANTAGENS & DESVANTAGENS & AUTORES \\
\hline direto & $\begin{array}{l}\text { - auxiliar no planejamento do } \\
\text { resultado econômico e estipular } \\
\text { preços; } \\
\text { - permite analisar o desempenho } \\
\text { dos gestores e das políticas } \\
\text { públicas com maior objetividade; } \\
\text { - é que a relação custo-benefício } \\
\text { da informação. }\end{array}$ & $\begin{array}{l}\text { - não observa os avanços da } \\
\text { gestão por atividades; } \\
\text { - atribui valor a bens e serviços } \\
\text { de forma arbitrária. }\end{array}$ & $\begin{array}{l}\text { Machado e Holanda } \\
\text { (2010); Schoeps } \\
\text { (1992); Machado } \\
\text { (2002); CFC (2012) } \\
\text { Alonso (1999). }\end{array}$ \\
\hline variável & $\begin{array}{l}\text { - estabelece um valor mínimo a } \\
\text { ser praticado; } \\
\text { - auxilia na tomada de decisão } \\
\text { quanto ao uso de recursos e no } \\
\text { que diz respeito a comprar ou } \\
\text { produzir um determinado item; } \\
\text { - - auxilia na distinção entre os } \\
\text { produtos mais rentáveis. }\end{array}$ & $\begin{array}{l}\text { - não é aceito pela auditoria } \\
\text { externa, nem pela legislação } \\
\text { fiscal; } \\
\text { - fere os princípios contábeis. }\end{array}$ & $\begin{array}{l}\text { Leone, Pedrosa e } \\
\text { Paulo (2014); } \\
\text { Megliorini (2006); } \\
\text { Abbas, Gonçalves e } \\
\text { Leoncine (2012). }\end{array}$ \\
\hline
\end{tabular}


Quadro 1 - Vantagens e desvantagens dos métodos de custeio

(Conclusão)

\begin{tabular}{|c|c|c|c|}
\hline MÉTODO & VANTAGENS & DESVANTAGENS & AUTORES \\
\hline $\begin{array}{c}\text { por } \\
\text { absorção }\end{array}$ & $\begin{array}{l}\text { - atende aos princípios contábeis; } \\
\text { - é o método aceito pela } \\
\text { legislação fiscal; } \\
\text { - aloca os custos diretos e } \\
\text { indiretos; } \\
\text { - é menos custoso para } \\
\text { implementar. }\end{array}$ & $\begin{array}{l}\text { - alto grau de arbitrariedade; } \\
\text { - o custo de um produto pode ser } \\
\text { influenciado, e sofrer variações, } \\
\text { em decorrência da alteração de } \\
\text { volume de um outro produto; } \\
\text { - não fornece informações } \\
\text { gerenciais precisas. }\end{array}$ & $\begin{array}{l}\text { Martins (2003); } \\
\text { Megliorini (2006); } \\
\text { Abbas, Gonçalves e } \\
\text { Leoncine (2012). }\end{array}$ \\
\hline pleno & $\begin{array}{l}\text { - leva em conta todos os gastos } \\
\text { ocorridos em uma organização; }\end{array}$ & $\begin{array}{l}\text { - fere os princípios contábeis; } \\
\text { - arbitrariedade da apuração. }\end{array}$ & $\begin{array}{c}\text { Vartanian e } \\
\text { Nascimento (1999); } \\
\text { Martins (2003); } \\
\text { Biazebete, Borinelli e } \\
\text { Camacho (2009). }\end{array}$ \\
\hline $\mathrm{ABC}$ & $\begin{array}{l}\text { - destina os custos de bens e } \\
\text { serviços a partir das bases de } \\
\text { atividades; } \\
\text { - auxilia nas situações de } \\
\text { reestruturações e } \\
\text { aperfeiçoamentos no processo; } \\
\text { - melhora as práticas de gestão; } \\
\text { - melhoria os processos; } \\
\text { - possibilita cortes específicos de } \\
\text { despesas em programas de ajuste } \\
\text { fiscal. }\end{array}$ & $\begin{array}{l}\text { - não separação dos custos fixos; } \\
\text { - demorada e dispendiosa para } \\
\text { aplicação; } \\
\text { - os dados são subjetivos e de } \\
\text { difícil validação; } \\
\text { - o processo de armazenamento e } \\
\text { processamento dos dados é } \\
\text { dispendiosa; } \\
\text { - não demonstra uma visão geral } \\
\text { em relação às oportunidades de } \\
\text { lucro; } \\
\text { - é de difícil atualização e } \\
\text { adaptação a novos fatores e } \\
\text { circunstâncias; } \\
\text { - não considera a capacidade } \\
\text { ociosa. }\end{array}$ & $\begin{array}{l}\text { Megliorini (2006); } \\
\text { Kaplan e Anderson } \\
\text { (2004a); Alonso } \\
\text { (1999); Abbas, } \\
\text { Gonçalves e } \\
\text { Leoncine (2012); } \\
\text { Nakagawa, 2001; } \\
\text { Monroy, Narisi e } \\
\text { Peláez (2012); } \\
\text { Machado (2005). }\end{array}$ \\
\hline TDABC & $\begin{array}{l}\text { - menos onerosa financeiramente } \\
\text { para implementação; } \\
\text { - mais fácil de ser executada; } \\
\text { - estima diretamente a demanda } \\
\text { de recursos gerada por transação, } \\
\text { produto ou cliente; } \\
\text { - identifica a capacidade de cada } \\
\text { departamento ou processo. }\end{array}$ & $\begin{array}{l}\text { - desconfiança nos resultados e } \\
\text { dificuldade em elaborar as } \\
\text { equações de tempo para } \\
\text { atividades ou ambientes não } \\
\text { estruturados; } \\
\text { - subjetividade nas estimativas de } \\
\text { tempo de cada atividade } \\
\text { individualmente; } \\
\text { - exigência de um elevado } \\
\text { volume de dados para estimar as } \\
\text { equações de tempo }\end{array}$ & $\begin{array}{l}\text { Pernot, Roodhooft e } \\
\text { Van Den Abbeele } \\
\text { (2007); Kaplan e } \\
\text { Anderson (2007); } \\
\text { Kaplan e Anderson } \\
\text { (2004a); Kaplan e } \\
\text { Anderson (2003); } \\
\text { Lee, Austin e } \\
\text { Pronovost (2014); } \\
\text { Souza et al (2012); } \\
\text { Boina et al (2015); } \\
\text { Zambon e Zorzo } \\
\text { (2014). }\end{array}$ \\
\hline
\end{tabular}

Fonte: Elaborado pela autora.

\subsection{TOMADA DE CONTAS ESPECIAL}

A Constituição Federal de 1988 (BRASIL, 1988) atribuiu ao TCU a competência de julgar as contas dos responsáveis por bens e valores públicos e daqueles que cometeram alguma 
irregularidade que resulte em dano ao erário. Para atendimento desta última atribuição, o TCU vem aprimorando suas ações, mediante um mecanismo chamado TCE (QUINTÃO e CARNEIRO, 2015, p. 478), que constitui um instrumento de controle a posteriori, de natureza administrativa, destinado a julgamento quanto à regularidade na guarda e aplicação dos recursos públicos, objetivando apurar os fatos, identificar os responsáveis e quantificar o dano (FERNANDES, 2015).

Além deste conceito, o mesmo autor cita um conceito dinâmico, para fins de reflexão acerca das mudanças que a TCE experimenta, afirmando que:

Tomada de Contas Especial é, na fase interna, um procedimento de natureza administrativa, instaurado em caráter excepcional que visa determinar a regularidade na guarda e aplicação de recursos públicos e, diante da irregularidade, na fase externa, um processo para julgamento da conduta dos agentes públicos (FERNANDES, 2015, p. 33, grifo do autor).

A TCE está prevista na Lei $n^{\circ} 8.443$ de 16 de julho de 1992 (BRASIL, 1992), a Lei Orgânica do TCU, que traz como fatos ensejadores para a TCE a omissão no dever de prestar contas; a falta de comprovação da aplicação dos recursos repassados pela União, mediante convênio, acordo, ajuste ou instrumento congênere; a ocorrência de desfalque ou desvio de dinheiros, bens ou valores públicos; e a prática de qualquer ato ilegal, ilegítimo ou antieconômico de que resulte em dano ao erário (BRASIL, 1992).

O início do processo deve ser realizado pelo órgão repassador dos recursos, que tem como obrigação adotar as providências para a instauração da TCE, de maneira imediata ao conhecimento do eventual dano ao erário, realizando a apuração, a identificação dos responsáveis e a quantificação do dano, sob pena de responsabilidade solidária, conforme IN n $^{\circ}$ 71 (BRASIL, 2012). Em casos excepcionais, o próprio TCU pode determinar a instauração, sendo chamada de TCE ex officio, ou a conversão dos processos administrativos que estejam em exame (FERNANDES, 2015). 
Após a conclusão das medidas administrativas, visando à apuração dos fatos e à instrução do processo, é elaborado um relatório conclusivo, remetido à autoridade instauradora “que o aprecia e envia ao controle interno para análise e emissão de parecer e certificado de auditoria" (FERNANDES, 2015, p. 383). Em seguida, a autoridade ministerial se manifesta quanto ao conhecimento do processo e das providências adotadas, visando resguardar o interesse público, remetendo os autos ao TCU (FERNANDES, 2015). Da apreciação do processo de TCE pelo TCU, podem resultar as decisões elencadas no Quadro 2:

Quadro 2 - Seleção de tomadas de decisões disponíveis ao TCU no processo de TCE

\begin{tabular}{|c|c|c|}
\hline DECISÃO & RESULTADO & OCORRE QUANDO \\
\hline \multirow[t]{2}{*}{ Preliminar } & Citação & $\begin{array}{l}\text { O relator ou o Tribunal, antes de pronunciar-se quanto ao mérito das } \\
\text { contas, resolve sobrestar o julgamento, ordenar a citação ou a audiência } \\
\text { dos responsáveis, rejeitar as alegações de defesa e fixar novo e } \\
\text { improrrogável prazo para recolhimento do débito; }\end{array}$ \\
\hline & Diligência & Outras diligências são necessárias ao saneamento do processo; \\
\hline \multirow{3}{*}{ Definitiva } & Regulares & $\begin{array}{l}\text { As contas expressam, de forma clara e objetiva, a exatidão dos } \\
\text { demonstrativos contábeis e a legalidade, a legitimidade, a economicidade } \\
\text { e a razoabilidade dos atos de gestão do responsável; }\end{array}$ \\
\hline & $\begin{array}{l}\text { Regulares com } \\
\text { ressalva }\end{array}$ & $\begin{array}{l}\text { Evidenciar impropriedade ou qualquer outra falta de natureza formal de } \\
\text { que não resulte dano ao erário; }\end{array}$ \\
\hline & Irregulares & For comprovado o dano ao erário; \\
\hline \multirow[b]{2}{*}{ Terminativa } & Iliquidáveis & $\begin{array}{l}\text { O caso fortuito ou de força maior, comprovadamente alheio à vontade do } \\
\text { responsável, tornar materialmente impossível o julgamento de mérito; }\end{array}$ \\
\hline & Arquivamento & $\begin{array}{l}\text { Se verificar a ausência de pressupostos de constituição e de } \\
\text { desenvolvimento válido e regular do processo; ou por economia } \\
\text { processual, sendo que neste caso o responsável continua devedor. }\end{array}$ \\
\hline
\end{tabular}

Fonte: Elaborado pela autora, baseado em Quintão e Carneiro (2015); Instrução Normativa n ${ }^{\circ} 71$ (BRASIL, 2012), Lei Orgânica do TCU (BRASIL, 1992)

A decisão definitiva do TCU, quanto à irregularidade e à imputação do débito, tem força de título executivo extrajudicial, obrigando o responsável a ressarcir o dano causado ao erário, conforme a Constituição Federal. Pode ainda ser determinado o encaminhamento dos autos ao Ministério Público, para uma possível apuração de ação civil ou penal, ou ao Ministério Público Eleitoral, para fins de verificação dos efeitos da denominada Lei da Ficha Limpa (QUINTÃO e CARNEIRO, 2015). 
O TCU ainda tem a prerrogativa de aplicar outras sanções, quanto ao descumprimento de alguma determinação ou em relação à irregularidade, de maneira isolada ou cumulativamente, conforme afirmam Quintão e Carneiro (2015):

1) Multa, que pode alcançar até $100 \%$ do valor atualizado do dano, independentemente do ressarcimento, e que também resulta em título executivo;

2) Inabilitação para o exercício de cargo em comissão ou função de confiança pelo prazo de cinco a oito anos;

3) Declaração de inidoneidade para licitar e contratar com o poder público, quando comprovada a ocorrência de fraude na licitação, ficando o licitante fraudador impedido de licitar e contratar com o poder público estadual e municipal, por até cinco anos.

Deve-se ter sempre em mente que o pressuposto para a instauração de um processo de TCE é a ocorrência de dano ao erário e que esta é "uma medida de exceção a ser utilizada de forma subsidiária aos outros instrumentos de controle" (SILVA, 2010, p. 158). Ao proceder com a instauração do processo, pode-se afirmar que o administrador público reconhece a ineficácia das suas medidas de controle administrativo, considerando que, mesmo tendo conhecimento do dano, o órgão deve adotar medidas administrativas para sanear o débito (SILVA, 2010, p.158).

A exigência para que o órgão instaurador da TCE esgote todas as medidas administrativas possíveis para sanar o débito, utilizando a prerrogativa de instauração em último caso, é justificável diante do alto custo que é gerado para continuidade do processo, considerando que envolve o órgão repassador dos recursos e o órgão de controle na denominada fase interna. Assim que é concluída, a TCE aciona o TCU, formando-se quase que um novo processo. Ao final, caso julgadas irregulares as contas, com imputação de débito ao agente 
causador do dano, a multa ou o ressarcimento ao erário não solvidos exigem a remessa da TCE ao Ministério Público junto ao Tribunal de Contas (MP-TCU), para as providências necessárias à execução, tendo em vista que a decisão do TCU tem eficácia de título executivo (QUINTÃO e CARNEIRO, 2015).

Vale ressaltar que o tema Tomada de Contas Especial é pouco explorado academicamente, pois de acordo com o resultado da pesquisa realizada no site de periódicos da CAPES este apresentou 5 resultados ${ }^{2}$, sendo apenas 1 artigo pertinente ao tema, sendo dos autores Quintão e Carneiro (2015), enquanto que na plataforma de artigos da Scielo não apresentou resultados. Tal carência justifica a adoção do presente tema de pesquisa.

\subsection{REEMBOLSO}

O conceito de reembolso adotado nessa pesquisa é em relação a recomposição do patrimônio lesado, sendo figurado como um ato de restituição do valor despendido pela administração pública a ser ressarcido pelo responsável.

Para o cálculo do reembolso de produtos e serviços públicos são essenciais as informações dos custos, pois assim é possível demonstrar como se atinge o valor e viabilizar a transparência dos dados aos gestores, ao público e ao Congresso (FASB, 1995).

De modo geral, para definir preços, deve-se satisfazer três fases: 1) escolha de uma amostra de dados, 2) utilização de métodos de corte e controle de plausibilidade e 3) definição de valor (SCHREYÖGG et al, 2006).

Os gestores devem ter conhecimento acerca da diferença entre custo e preço, pois pode ocorrer de uma entidade entrar em acordo com uma outra, para o fornecimento de bens e

\footnotetext{
${ }^{2}$ Consulta realizada em junho/2016.
} 
serviços a um determinado preço para fins de reembolso, mas que este pode ou não ser suficiente para recuperar os custos totais dispendidos (FASB, 1995).

Nesses casos, normalmente, o acordo é voluntário e estabelecido entre agências, que muitas vezes contam com fundos que são repostos para tornar a prestação dos produtos e serviços autossustentáveis mediante a recuperação dos custos (FASB, 1995).

Organizações que são submetidas ao financiamento reembolsável são frequentemente provocadas por seus consumidores a esmiuçar e explicar seus custos. Esta cobrança por transparência pode se tornar um problema, caso os clientes se recusem em reembolsar os custos enquanto não tiverem informações auditadas (ORACLE, 2010).

Com base nas pesquisas realizadas, e nas referências já citadas, pode-se inferir que o setor de prestação de serviços públicos em que se encontra a maior parte do uso disseminado de mensuração de custos, para posterior reembolso, é a área de saúde, tendo em vista o custo dos procedimentos, a alta demanda, a variedade de critérios, o envolvimento de recursos públicos e a necessidade de compartilhamento de ações entre o setor público e o privado, não tendo sido identificado estudo específico para o cálculo do reembolso de processo de Tomada de Contas Especial. Dessa maneira, a presente pesquisa contribui para o conhecimento desses dois temas: TCE e ressarcimento ao erário de gastos indevidos.

Schreyögg et al. (2006) elaboraram uma análise comparativa entre 9 países europeus e constataram que a forma como as informações são usadas para esclarecer os custos dos serviços de saúde, e como calcular seu reembolso, é distinta entre as nações daquele continente. No entanto, a categorização dos pacientes, que auxilia no cálculo das taxas de reembolso, é equivalente, pois tem como embasamento o método da Health Care Financing Administration (HCFA), apesar de os países estudados proclamarem que seus sistemas de classificação de pacientes sejam singulares e específicos para atender exigências da legislação de cada um deles. 
O sistema de classificação de pacientes do HCFA (órgão estadunidense que supervisiona o programa Medicare, que é um programa social de saúde dos Estados Unidos) usa a lista "Diagnosis Related Groups" (DRGs), que constitui um sistema de classificação de pacientes internados em hospitais que atendem casos agudos (NORONHA et al, 1991). Esse sistema foi popularizado, em 1983, nos Estados Unidos para o reembolso de fornecedores do programa e continua sendo aperfeiçoado (SCHREYÖGG et al, 2006). Concebida, a princípio, como um mecanismo de gestão de dados para os médicos acompanharem a qualidade, a utilização dos serviços e a categorização dos pacientes, atualmente é usado também como um sistema de pagamento prospectivo em diversos lugares do mundo (SCHREYÖGG et al, 2006).

A cobertura dos serviços que vão ser repostos pode divergir de país para país, alguns podem usar uma única técnica para todo seu território ou cada região pode ter sua norma ou processo. Na coleta de dados que subsidiam o cálculo das taxas de reembolso, o modo de triagem dos hospitais que farão parte da amostra (podem ser todos ou apenas alguns) está sujeito aos recursos financeiros que o país possa investir, quanto mais hospitais, maior o investimento de sistema de custos (SCHREYÖGG et al, 2006).

Outros mecanismos de reembolso aplicam-se quando as autoridades de saúde regionais contratam certos tipos de procedimentos de diagnóstico ou cirúrgicos, bem como serviços auxiliares com prestadores privados. Contratantes terceirizados implicam cerca de $15 \%$ da despesa pública. Nesses casos, pagamentos são retrospectivos e os fornecedores são pagos por caso ou por processo. Os preços são estabelecidos com referência às tarifas oficiais e são um resultado da negociação, isto é, não estão ligados a custos unitários reais (SÁNCHEZMARTÍNEZ et al, 2006).

Os países que tem o sistema financiado principalmente por impostos costumam usar um sistema DRG para três propósitos: definir preços para os prestadores de serviço privado 
contratados (por exemplo, Itália) para taxas de reembolso definidas entre diferentes regiões, como parte de um sistema regionalizado (por exemplo, Dinamarca) ou para aumentar a eficiência dentro de hospitais que pertencem apenas ao Serviço Nacional de Saúde (por exemplo, Espanha, exceto para Catalunha) (SCHREYÖGG et al, 2006).

Já na Alemanha, por exemplo, de acordo com Vogl (2012), pode-se inferir que o mecanismo de reembolso depende do sistema de contabilidade de custos para apuração, o qual necessita de soluções práticas que garantam a confiabilidade dos dados. $\mathrm{O}$ uso de dados antigos torna o ressarcimento impreciso e inconsistente.

As duas questões-chaves e de longa data em torno do reembolso de dispositivos médicos coreanos são como agilizar a entrada de novas tecnologias ou dispositivos inovadores no mercado com preços adequados e reduzir satisfatoriamente o reembolso de dispositivos mais antigos (LEE e SALONE, 2014).

A definição de melhor prática é claramente difícil, porque o ajuste ideal (ou seja, na medida em que os custos são refletidos por preços) em cada país depende de um grande número de variáveis, incluindo a prática clínica, as variações regionais na área da saúde, a utilização, a distribuição de custos, as estratégias para adaptar inovações e os dados demográficos (SCHREYÖGG et al, 2006).

Problema que pode surgir, para apuração de custos e determinação de valores de reembolso, e que foi identificado na França, é quando se tem falta de transparência na forma como são calculadas e na complexidade das regras de fixação de preços e a instabilidade do processo de tomada de decisão (BELLANGER e TARDIF, 2006).

Vias de reembolso em todos estes países precisam evoluir para acomodar novos métodos de cuidados com a saúde, processos para reembolso, cobertura e preços que avaliam o valor global de dispositivos médicos em termos de resultados de saúde (LEE et al, 2015), 
podendo-se refletir nos procedimentos de apuração dos custos de TCE, que já sofrem com o impacto de exigências provenientes de novas legislações.

Em relação ao SUS, a forma de remuneração dos serviços prestados pelos Estados e Municípios, que desempenham essa atividade de forma descentralizada, recebendo os repasses da União, conforme previsto na Lei nº 8.080 (BRASIL, 1990a), observa apenas a relação econômico-financeira como critério para fixação dos valores, podendo apresentar defasagem como ocorreu em 2003 e 2004, em que o Ministério da Saúde reajustou as tabelas de procedimentos ambulatoriais e hospitalares (média e alta complexidade) do SUS, considerando que muitos já estavam defasados havia mais de dez anos (BRASIL, 2002).

Já na prestação de serviços privados de saúde, há uma prática de cobrança de valores diferenciados entre atendimento particular e de plano de saúde, sem a utilização de critérios de custeio para essa diferenciação, além de tais cobranças utilizarem os serviços de contabilidade apenas para o cumprimento das obrigações fiscais e tributárias, sem um tratamento mais cuidadoso dos custos incorridos nos serviços (MAIA et al, 2009).

No âmbito jurídico brasileiro existe o estabelecimento de custas judiciais, cuja natureza é de tributo, cobrado pelo Estado para exercer a atividade jurisdicional, a ser pago pelas partes no processo (LONGO e LONGO, 2011) e que foi estabelecido pela Lei n $^{\circ}$ 9.289, de 4 de julho de 1996 (BRASIL, 1996).

\subsection{SISTEMA DE INFORMAÇÕES DE CUSTOS DO GOVERNO FEDERAL (SIC)}

A obrigatoriedade de a Administração Pública ter um sistema de custos remonta ao ano 1964, quando a Lei no 4320 (BRASIL, 1964) estabeleceu que o sistema de contabilidade da União deveria determinar os custos dos serviços industriais, sendo seguido pelo Decreto-Lei $\mathrm{n}^{\circ}$ 200 (BRASIL, 1967), que ampliou a apuração para os serviços, de forma a evidenciar os 
resultados da gestão, e pela a Lei de Responsabilidade Fiscal (LRF), que impôs ao Governo Federal que mantivesse um sistema de custos para avaliação e acompanhamento da gestão orçamentária, financeira e patrimonial.

A edição da Portaria n ${ }^{\circ}$ 157, de 9 de março de 2011 (BRASIL, 2011) definiu, como objetivo do Sistema de Custos do Governo Federal “(...) proporcionar conteúdo informacional para subsidiar as decisões governamentais de alocação mais eficiente de recursos e gerar as condições para a melhoria da qualidade do gasto público".

Já a Portaria $\mathrm{n}^{\mathrm{o}}$ 716, de 24 de outubro de 201, da Secretaria do Tesouro Nacional (BRASIL, 2011b) trouxe o complemento ao conceito do Sistema de Custos do Governo Federal, em ser um "sistema estruturante do Governo Federal" e a definição do Sistema de Informações de Custos (SIC) como um "sistema informacional do Governo Federal que tem por objetivo o acompanhamento, a avaliação e a gestão dos custos dos programas e das unidades da Administração Pública Federal e o apoio aos Gestores no processo decisório”.

Esse sistema utiliza a extração de dados dos sistemas estruturantes da Administração Pública Federal que são: Sistema Integrado de Administração de Pessoas (SIAPE), Sistema Integrado de Administração Financeira do Governo Federal (SIAFI) e Sistema de Informações Gerenciais e de Planejamento (SIGPLAN), até o ano de 2011, sendo substituído, a partir de 2012, pelo Sistema Integrado de Planejamento e Orçamento (SIOP) para a geração de informações (BRASIL, 2010).

Integram o Sistema de Custos do Governo Federal: a Secretaria do Tesouro Nacional (STN), como órgão central, e, como os órgãos setoriais, as unidades de gestão interna dos Ministérios e da Advocacia-Geral da União, responsáveis pelo acompanhamento de custos no Sistema de Informações de Custos (BRASIL, 2011a). Machado (2005) retrata os principais objetivos do SIC, que são: fornecer dados e informações que possibilitem avaliar a eficiência 
na utilização dos recursos públicos, a atuação eficaz dos gestores e a aplicação efetiva das políticas públicas, que são feitas para solucionar problemas apresentados pela sociedade.

Porém, conforme afirmam Matos et al (2013, p. 391) “este sistema não está efetivamente implantado e não oferece o custo dos serviços prestados pela União". O SIC aplica o método de Custeio Direto e possui quatros objetos de custos. Utiliza, assim, apenas os custos que estão diretamente relacionados a tais objetos. De acordo com Suzart (2012, p. 53), os objetos de custo são: “ (i) custo de pessoal; (ii) custos dos produtos das ações orçamentárias; (iii) custos dos programas do Plano Plurianual; e, (iv) custos das unidades orçamentárias”. Para o SIC, quando relacionados à entidade que vai utilizá-lo, não há parâmetros de custeio pré-estabelecidos, devendo a escolha do método estar apoiada na "disponibilidade de informações e no volume de recursos necessários para obtenção das informações ou dados".

De acordo com os objetos de custos, a entidade pode adotar mais de uma metodologia de custo, conforme afirma Silva (2011). O mesmo autor afirma que o sistema de custos deve ser estruturado de forma que permita a consulta aos dados em qualquer tempo, com a finalidade de subsidiar o processo decisório dos gestores.

Para ter acesso ao SIC é necessário ter acesso ao SIAFI, sendo o principal sistema de registro orçamentário, financeiro e contábil, no perfil “TESCUSTOS”. O acesso às informações é por meio do "SIAFI GERENCIAL", no qual se pode realizar a elaboração de planilhas com os parâmetros de pesquisa estabelecidos.

Itens que devem ser aperfeiçoados, visando à melhoria das informações produzidas por esse Sistema, são o alinhamento das informações financeiras e contábeis às normas internacionais, para possibilitar o comparativo de desempenho com outros países, uma melhor integração entre os sistemas gerenciais governamentais, visando ao acompanhamento e à tomada de decisão, e a alocação apenas de custos diretos, já que há custos indiretos envolvidos nos serviços 
prestados, que, caso fossem considerados, tornariam mais completas as informações disponíveis no Sistema (SUZART, 2012).

O Quadro 3 detalha as principais características do SIC, envolvendo diversos aspectos.

Quadro 3 - Principais características do Sistema de Informações de Custos do Governo Federal

\begin{tabular}{|c|c|}
\hline ITEM DE COMPARAÇÃO & CARACTERÍSTICAS \\
\hline Funções das informações sobre custos. & $\begin{array}{l}\text { Controlar e reduzir custos; } \\
\text { Definir preços e taxas; } \\
\text { Avaliar o desempenho financeiro; } \\
\text { Avaliar os programas governamentais; } \\
\text { Auxiliar em decisões econômicas; } \\
\text { Tornar transparente o uso de recursos públicos. }\end{array}$ \\
\hline Método de alocação de custos. & Custeio Direto \\
\hline Tipos das informações sobre custos. & $\begin{array}{l}\text { Custo Total; } \\
\text { Custo Controlável. }\end{array}$ \\
\hline $\begin{array}{l}\text { Reconciliação das informações } \\
\text { financeiras }\end{array}$ & $\begin{array}{l}\text { Realiza reconciliação das informações financeiras; } \\
\text { A Contabilidade Pública brasileira não adota completamente as } \\
\text { Normas Internacionais de Contabilidade. }\end{array}$ \\
\hline Integração sistêmica & $\begin{array}{l}\text { Integração parcial entre o sistema de custos e demais sistemas } \\
\text { utilizados. }\end{array}$ \\
\hline Relatórios fornecidos pelo sistema & Relatórios padronizados e hierarquicamente vinculados. \\
\hline $\begin{array}{l}\text { Tópicos relevantes sobre a implantação } \\
\text { do sistema }\end{array}$ & $\begin{array}{l}\text { Implantação de maneira progressiva; } \\
\text { Treinamento aos agentes públicos. }\end{array}$ \\
\hline
\end{tabular}

Fonte: Suzart (2012, p. 53).

Dessa maneira, o custeio por atividades em geral e o TDABC em particular não parecem particularmente aderentes ao SIC, o que está alinhado com a sua proposta de atendimento das demandas de custos de toda a Administração Pública Federal. 


\section{METODOLOGIA}

Este Capítulo apresenta os aspectos metodológicos que foram utilizados nesta pesquisa para atingir os objetivos propostos, evidenciando o desenho e a tipificação da pesquisa, a justificativa para escolha do caso, os instrumentos de pesquisa e a coleta de dados, a caracterização do perfil dos participantes e a forma de análise e o tratamento dos dados.

\subsection{DESENHO E TIPIFICAÇÃO DA PESQUISA}

A pesquisa utilizou a abordagem qualitativa, tendo em vista os objetivos de análise do custo de processo e a proposta de meios de reembolso para a Administração Pública, revelando aspectos gerenciais e processuais (DALCI, TANIS e KOSAN, 2010). Nesse sentido, ela é descritiva e aplicada, porque relata a aplicação de modelo teórico já existente na apuração do custo do processo de TCE, assim como realiza sugestões para adaptação do sistema e propõe meios viáveis ao reembolso pela Administração Pública. Nos moldes previstos por Sampieri et al (2006), estudos descritivos procuram medir, avaliar ou coletar dados sobre diversos aspectos, dimensões ou componentes do fenômeno a ser pesquisado.

O método de pesquisa utilizado foi o estudo de caso, que segundo Yin (2010) é uma investigação empírica com foco em observar um fenômeno em profundidade e no contexto onde ocorre. Este estudo apura o custo do processo de TCE em um órgão do setor público buscando oferecer meios de obtenção do reembolso desse gasto.

A operacionalização do estudo de caso ocorreu por meio de pesquisa documental, que serviu para orientar e respaldar a aplicação do método de custeio TDABC, e o levantamento de opinião, que fundamentou a pertinência do reembolso do custo do processo de TCE, sendo detalhado os instrumentos em momento oportuno. 
A escolha desse método de pesquisa se deu pelo fato de ter sido desenvolvido em um determinado órgão público com a especificidade em abordar um processo em especial, que é o de TCE, estando alinhado aos preceitos de aplicação de estudo de caso, conforme afirma Ludwig (2009, p. 58): “o estudo de caso diz respeito a uma investigação de fenômenos específicos e bem delimitados, sem a preocupação de comparar ou generalizar”.

No que se refere ao contexto temporal, o recorte é transversal, tendo em vista a apuração do custo do processo de TCE, que considerou os dados médios obtidos em um determinado momento, sem comparativo com períodos anteriores, assim como o levantamento de opinião, que ofereceu um panorama do perfil administrativo em um determinado momento do tempo, tendo em vista que os dados foram coletados em um determinado ponto do tempo, nos moldes do que afirma Hair et al (2005).

\subsection{JUSTIFICATIVA DA ESCOLHA DO CASO}

Em relação ao órgão, este foi escolhido pelo fato da pesquisadora fazer parte da equipe, facilitando o acesso, e tornando a coleta de dados mais conveniente, e por ter apresentado quantidades e valores expressivos relacionados à TCE, tanto no ano de 2016, quanto no acumulado de 2002 a 2015, conforme Tabela 1, que lista os processos remetidos ao TCU, disponível no sítio eletrônico da Controladoria Geral da União (CGU) (BRASIL, 2016).

A coluna valor refere-se ao montante atualizado no momento da instauração da TCE, realizada pelo órgão, podendo aumentar ou diminuir quando do julgamento pelo TCU, considerando a aplicação de juros e atualização monetária. Ademais, esse numerário ainda não consideram os custos para sua apuração, objeto desta pesquisa. 
Tabela 1 - Dados dos quantitativos e valores das TCEs de 2016 e acumulado 2002-2015

\begin{tabular}{|c|c|c|c|c|c|c|}
\hline \multirow{3}{*}{ ÓRGÃOS } & \multicolumn{2}{|r|}{ 2016* } & \multicolumn{4}{|c|}{ ACUMULADO 2002/2015 } \\
\hline & \multirow{2}{*}{ QTD } & \multirow{2}{*}{ VALOR $(\mathrm{R} \$)$} & \multirow{2}{*}{ QTD } & \multirow{2}{*}{ VALOR $(\mathrm{R} \$)$} & QTD & VALOR \\
\hline & & & & & $(\%)$ & $(\%)$ \\
\hline PR - Presidência da República & - & - & 3 & $3.671 .918,34$ & 0,01 & 0,02 \\
\hline MME - Ministério de Minas e Energia & - & - & 10 & $4.607 .835,17$ & 0,05 & 0,03 \\
\hline $\begin{array}{l}\text { MDIC - Ministério do Desenvolvimento, Indústria e } \\
\text { Comércio Exterior }\end{array}$ & 3 & $13.380 .504,71$ & 109 & $68.160 .665,22$ & 0,54 & 0,43 \\
\hline MT - Ministério dos Transportes & 4 & $14.408 .139,73$ & 125 & $763.280 .472,50$ & 0,62 & 4,81 \\
\hline MCid - Ministério das Cidades & 10 & $7.140 .612,51$ & 236 & 198.653.201,54 & 1,16 & 1,25 \\
\hline MJ - Ministério da Justiça & 3 & $5.259 .567,94$ & 243 & $274.159 .070,77$ & 1,2 & 1,73 \\
\hline ME - Ministério do Esporte & 11 & $12.074 .825,87$ & 358 & $235.312 .890,11$ & 1,76 & 1,48 \\
\hline MC - Ministério das Comunicações & 5 & $905.500,12$ & 362 & $57.128 .364,19$ & 1,78 & 0,36 \\
\hline $\begin{array}{l}\text { MAPA - Ministério da Agricultura, Pecuária e } \\
\text { Abastecimento }\end{array}$ & 3 & $3.111 .152,31$ & 382 & $185.325 .878,92$ & 1,8 & 1,17 \\
\hline MDA - Ministério do Desenvolvimento Agrário & 21 & $23.561 .721,53$ & 471 & $433.689 .525,33$ & 2,32 & 2,73 \\
\hline MF - Ministério da Fazenda & 1 & $100.913,17$ & 551 & $683.222 .861,78$ & 2,72 & 4,31 \\
\hline MMA - Ministério do Meio Ambiente & 10 & $3.443 .605,31$ & 589 & $374.791 .400,44$ & 2,9 & 2,36 \\
\hline MCTI - Ministério da Ciência, Tecnologia e Inovação & 7 & $9.529 .697,67$ & 666 & $274.406 .330,90$ & 3,28 & 1,73 \\
\hline MinC - Ministério da Cultura & 14 & $28.011 .296,63$ & 725 & $495.554 .330,70$ & 3,57 & 3,12 \\
\hline $\begin{array}{l}\text { MDS - Ministério do Desenvolvimento Social e Combate } \\
\text { à Fome }\end{array}$ & 65 & $31.502 .297,02$ & 853 & $274.044 .092,54$ & 4,2 & 1,73 \\
\hline MP - Ministério do Planejamento, Orçamento e Gestão & - & - & 1.000 & $490.881 .342,60$ & 4,93 & 3,09 \\
\hline MTPS - Ministério do Trabalho e Previdência Social & 32 & $31.308 .987,41$ & 1.154 & $1.695 .744 .065,48$ & 5,69 & 10,69 \\
\hline MI - Ministério da Integração Nacional & 24 & $326.446 .811,70$ & 1.274 & $2.188 .518 .068,74$ & 6,28 & 13,79 \\
\hline MTur - Ministério do Turismo & 51 & $44.194 .219,22$ & 1.449 & $683.123 .438,32$ & 7,14 & 4,3 \\
\hline MEC - Ministério da Educação & 40 & $62.730 .559,56$ & 4.367 & $1.928 .673 .784,77$ & 21,52 & 12,15 \\
\hline MS - Ministério da Saúde & 105 & $118.020 .100,76$ & 5.366 & 4.555.960.367,85 & 26,44 & 28,71 \\
\hline Total Geral & 409 & 735.130.513,17 & 20.293 & $15.868 .909 .906,21$ & 100 & 100 \\
\hline
\end{tabular}

Fonte: BRASIL. Controladoria Geral da União. Grifado pela autora. * Atualizado até 31/03/2016.

\subsection{1. Órgãos envolvidos na Tomada de Contas Especial}

De acordo com Fernandes (2015), o fluxo do processo que envolve a instauração da TCE consiste na identificação do dano ao erário, por parte do órgão ou da entidade responsável pelo gasto ou pelo patrimônio público, que adota as medidas administrativas de reparação desse dano, passando por certificação do órgão de controle interno, no caso a Controladoria-Geral da União (CGU), sendo essa considerada a fase interna. Após esses procedimentos, enfim, o 
processo é encaminhado para julgamento do Tribunal de Contas da União (TCU), que, a partir de então, passa a ser considerada a fase externa (FERNANDES, 2015).

Esse fluxo refere-se aos órgãos envolvidos no processo, Figura 1, sendo a etapa 1 uma fase preliminar, realizada pela área técnica. As etapas 2 a 4 referem-se à fase interna da TCE, enquanto a partir da 5 é considerada a fase externa, iniciando pelo TCU. O MP-TCU e a AGU atuam na execução da dívida, posterior ao julgamento. As áreas técnicas identificam e caracterizam o dano ao erário e oferecem a ampla defesa e o contraditório aos responsáveis apontados no processo e após essas medidas administrativas, caso não sejam sanadas as pendências, remetem o processo à Coordenação de Contabilidade do FNS para verificar a conformidade da documentação e instaurar a competente TCE.

Figura 1 - Órgãos envolvidos no processo de TCE, com início no Ministério da Saúde

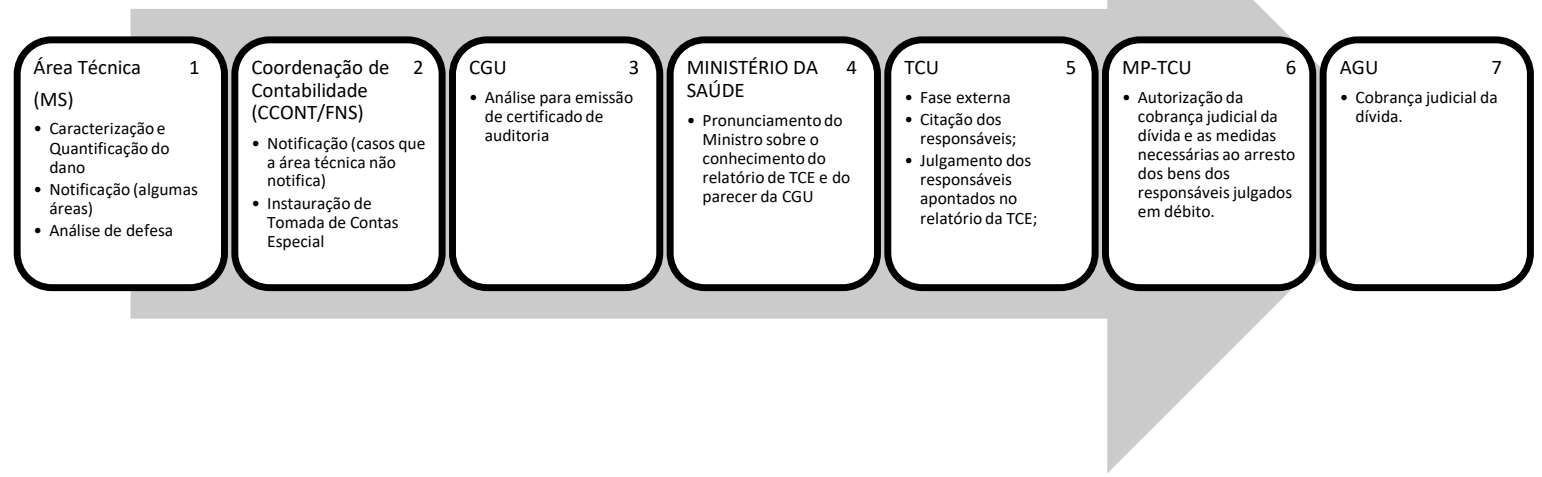

Fonte: Elaborado pela autora.

Depois de instaurada a TCE, o processo é remetido para CGU que analisa a pertinência do processo para fins de concessão do certificado de auditoria. Em seguida, o processo retorna ao Ministério da Saúde, para pronunciamento Ministerial, atestando ter tomado conhecimento do relatório do tomador de contas especial e do parecer do órgão de controle interno e só a partir 
de então o processo pode ser enviado ao TCU, encerrando a fase interna para iniciar a fase externa, conforme IN n ${ }^{\circ} 71$ (BRASIL, 2012).

No TCU é realizada a citação dos responsáveis apontados no processo e, a partir do pronunciamento dos envolvidos, é realizado o julgamento. A participação do MP-TCU ocorre na penúltima fase da decisão final, com a atribuição de fazer valer a ordem jurídica, participando também, após o julgamento, quando há a autorização para cobrança judicial da dívida e a adoção das medidas necessárias ao arresto dos bens dos responsáveis julgados em débito. Em relação à última etapa, a AGU atua junto ao Judiciário para realizar a cobrança judicial.

Vale destacar que essa pesquisa se detém a apurar o custo do processo de TCE apenas da Etapa 2 da Figura 1, que é na CCONT/FNS, que efetua a instauração do processo de TCE. Todos os processos instaurados, e que são julgados irregulares pelo TCU passam por todas as fases da Figura 1, e caso a TCE seja julgada regular, se encerra no TCU.

Portanto, para elucidar as fases de instauração da TCE e o momento da instauração da TCE, o Quadro 4 demonstra as etapas “antes", "durante" e "depois" no FNS e nos demais órgãos envolvidos.

Quadro 4 - Fases da instauração da TCE no FNS/MS

\begin{tabular}{|l|c|c|c|c|c|}
\hline \multicolumn{1}{|c|}{ FASE } & \multicolumn{3}{c|}{ INTERNA } & \multicolumn{2}{c|}{ EXTERNA } \\
\hline \multicolumn{1}{|c|}{ ÓRGÃO } & ANTES & DURANTE & DEPOIS & JULGAMENTO & COBRANÇA \\
\hline 1- Áreas técnicas do MS & $\mathrm{X}$ & & & & \\
\hline 2-Coordenação de Contabilidade & $\mathrm{X}$ & $\mathrm{X}$ & $\mathrm{X}$ & & \\
\hline 3 - Controle Interno & & & $\mathrm{X}$ & & \\
\hline 4- Ministério da Saúde & & & $\mathrm{X}$ & & $\mathrm{X}$ \\
\hline 5- Tribunal de Contas da União & & & & & $\mathrm{X}$ \\
\hline $\begin{array}{l}\text { 6 - Ministério Público junto ao } \\
\text { TCU }\end{array}$ & & & & & $\mathrm{X}$ \\
\hline $\begin{array}{l}7-\text { Advocacia Geral da União } \\
\text { (AGU) }\end{array}$ & & & & & \multirow{2}{*}{} \\
\hline
\end{tabular}

Fonte: Elaborado pela autora. 
A etapa "antes" refere-se à atuação das áreas técnicas para consolidar as informações e instruir o processo administrativo para remessa à CCONT, após insucesso na tentativa inicial de composição do dano. A etapa "durante" é a fase de instauração da TCE, em que se observam os pressupostos pertinentes de instauração e processamento. A etapa "depois" engloba as fases de certificação pelo órgão de controle interno, que é a CGU, e a remessa ao TCU pelo Ministro de Estado. A fase externa engloba o TCU para o julgamento e a AGU para a cobrança, com o MP-TCU participando das duas ações.

\subsubsection{Fundo Nacional de Saúde}

O FNS é uma Diretoria inserida na estrutura do Ministério da Saúde (MS), fazendo parte da Administração Direta, que instaura a TCE por meio da Coordenação de Contabilidade (CCONT/FNS).

A Coordenação de Contabilidade é um setor que está inserido na estrutura regimental do MS, conforme se observa na Figura 2, que se limitou a ilustrar a hierarquia do setor dentro do Ministério. As demais áreas técnicas fazem parte de todo o resto da cadeia hierárquica do MS. O FNS está subordinado hierarquicamente à Secretaria Executiva do MS.

O Fundo Nacional de Saúde (FNS) foi instituído pelo Decreto nº 64.867, de 24 de julho de 1969, como um fundo especial, destinado a prover as ações relacionadas a saúde individual e coletiva, coordenados ou desenvolvidos pelo Ministério da Saúde (MS).

Os fundos de saúde são uma modalidade de gestão de recursos de natureza financeira e contábil, fiscalizados pelos Conselhos de Saúde, a quem compete controlar a execução das políticas de saúde, inclusive nos aspectos econômicos e financeiros, em suas respectivas esferas administrativas, conforme a Lei $\mathrm{n}^{\circ} 8.142$ (BRASIL, 1990b). A Constituição Federal cita a 
necessidade de aplicação em conta única de todos os recursos destinados às ações e aos serviços públicos de saúde gerenciados por meio destes fundos.

Figura 2 - Organograma da estrutura hierárquica regimental em que está inserido o FNS

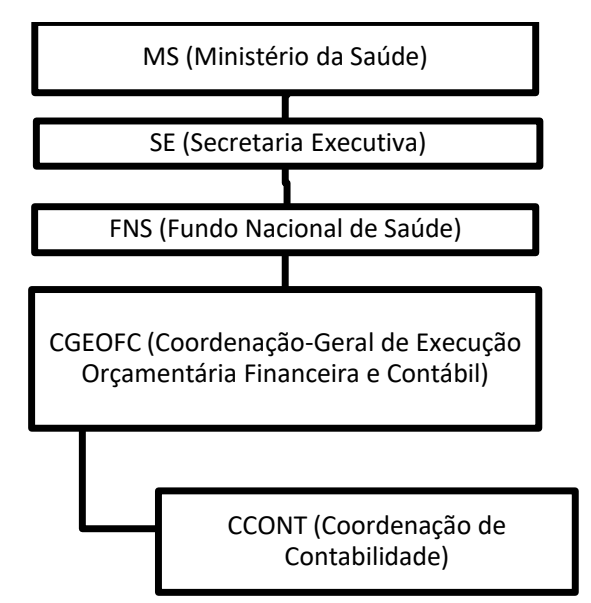

Fonte: Elaborado pela autora, com base na Portaria GM n³ 3.965, de 14 de dezembro de 2010 (BRASIL, 2010).

A gestão dos recursos do FNS é administrada pelo Diretor Executivo, designado pelo MS, a quem compete planejar, coordenar, desenvolver e controlar as atividades de execução orçamentária, financeira e contábil, inclusive aquelas executadas por unidades descentralizadas, com a coordenação e o apoio da secretaria-executiva do MS, conforme Decreto ${ }^{\circ} 8.065$, de 7 de agosto de 2013 (BRASIL, 2013). Compete ainda ao FNS instaurar o processo de TCE dos recursos do SUS alocados ao Fundo.

O FNS tem a missão de "contribuir para o fortalecimento da cidadania, mediante a melhoria contínua do financiamento das ações de saúde”, o que o leva a criar meios de acesso à informação a toda sociedade, relativos aos recursos administrados, que se destinam a “financiar as despesas correntes e de capital do Ministério da Saúde, de seus órgãos e entidades 
da administração direta e indireta, integrantes do SUS", conforme sítio eletrônico do FNS na aba histórico (BRASIL, 2016, p.1).

A principal destinação dos recursos alocados no FNS são as transferências a Estados, Distrito Federal e Municípios, com a finalidade "de que esses entes federativos realizem, de forma descentralizada, ações e serviços de saúde, bem como investimentos na rede de serviços e na cobertura assistencial e hospitalar, no âmbito do SUS" conforme sítio eletrônico do FNS na aba histórico (BRASIL, 2016, p.1). Essas transferências ocorrem por intermédio de fundo a fundo, convênios, contratos de repasses e termos de cooperação.

Subordinada à Diretoria Executiva do FNS, encontra-se a Coordenação de Contabilidade (CCONT/FNS), que além de fazer parte da estrutura regimental do Ministério da Saúde, caracteriza-se como uma setorial contábil, pertencente ao Sistema de Contabilidade Federal (SCF).

Dentre as atribuições dessa setorial contábil, enfatiza-se verificar o cálculo do débito e efetuar o registro contábil referente a tomadas de contas dos responsáveis por bens e valores públicos e de todo aquele que der causa a algum tipo de irregularidade que resulte em dano ao erário, previamente apurado, assim como efetuar a baixa contábil, mediante recebimento ou cancelamento do débito, conforme Decreto nº 6.976, de 7 de outubro 2009 (BRASIL, 2009).

Desta forma, foi imputado a CCONT/FNS, dentre outras atribuições, propor ao ordenador de despesas do FNS a instauração de Tomada de Contas Especial, já que uma das atividades é efetuar registros nos sistemas de informações contábeis, que se encontram alinhados às atividades do SCF, conforme Instrução Normativa $n^{\circ} 71$ (BRASIL, 2012) e Portaria $\mathrm{n}^{\circ} 3.965$, de 14 de dezembro de 2010 do Ministério da Saúde (BRASIL, 2010).

O escopo desse estudo de caso restringe-se à apuração do custo do processo de TCE no FNS. A Coordenação responsável pela instauração da TCE é a CCONT/FNS, que possui uma 
Divisão de Tomada de Contas Especial (DITCE) e um Serviço de Tomada de Contas Especial (SETCE), de acordo com o Regimento Interno do MS (BRASIL, 2010). Para o desenvolvimento de suas atividades, as unidades informais com atribuições específicas no fluxo das atividades da coordenação são: a) apoio; b) diligência; c) cobrança; d) ponto focal; e e) instauração de TCE, totalizando cinco equipes, distribuídas conforme a Figura 3:

Figura 3 - Estrutura da Coordenação de Contabilidade

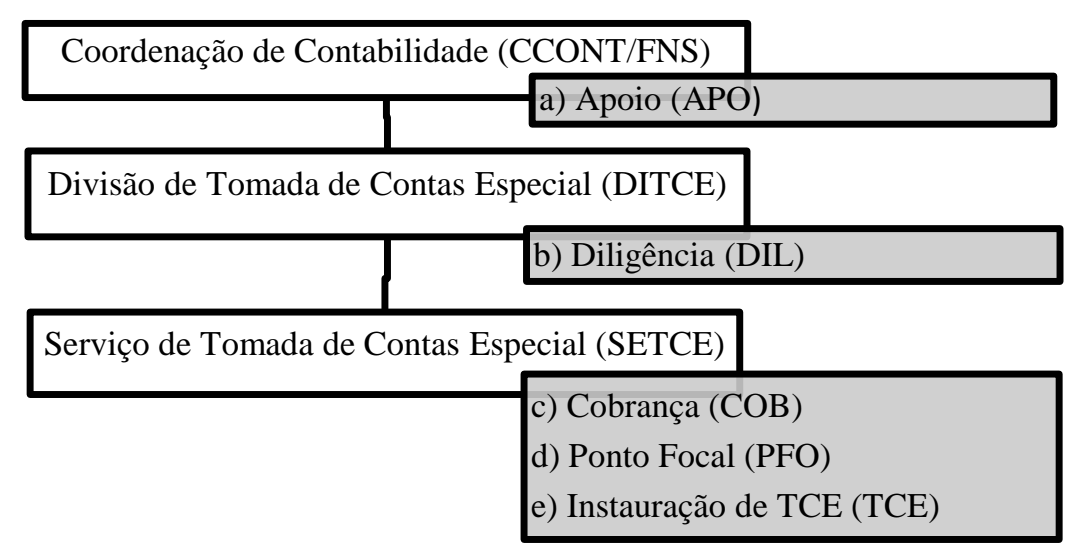

Fonte: Elaborado pela autora.

A instauração da TCE está sob a supervisão do SETCE, mas envolve também a DITCE, ambas subordinadas à CCONT/FNS.

\subsubsection{Escolha do método}

Em relação à escolha do método de custeio TDABC, foi levado em consideração as vantagens que este apresenta: em possibilitar a mensuração do custo em nível de atividades, (REDDY, VENTER e OLIVIER, 2012; SCHMIDT, SANTOS e LEAL, 2009), a facilidade de execução e por ser menos onerosa financeiramente para implementação (KAPLAN e ANDERSON (2007). 
Os métodos de custeio tradicionais, como o método Direto ou por Absorção, têm a limitação em restringir os objetos de custeio aos produtos e no setor público os produtos são geralmente de natureza complexa e sem similar no mercado (ALONSO, 1999).

Além disso, com base na conclusão do estudo bibliométrico acerca das publicações nacionais sobre o TDABC, Catânio, Pizzo e Moraes (2015, p. 13) sugerem que sejam desenvolvidos mais estudos empíricos sobre TDABC, tendo em vista que "o tema carece de publicações em congressos e periódicos, dissertações de mestrado e, principalmente, teses de doutorado envolvendo a temática”.

\subsection{COLETA DE DADOS E CARACTERIZAÇÃO DOS INSTRUMENTOS DE PESQUISA}

De acordo Yin (2010), há uma diversidade de instrumentos de coleta de dados que podem ser utilizados no estudo de caso e que as múltiplas fontes fortalecem a abordagem dos aspectos que se está estudando. Os principais instrumentos informados por Yin (2010) são: documentos, arquivos gravados, entrevistas, observação direta, observação participante e artefatos físicos. Já para a análise das atividades, de acordo com Nakagawa (2001), as técnicas de coleta de dados mais utilizadas são: observação, registros de tempo, questionários, storyboards e entrevistas.

Assim, para lograr os objetivos específicos da presente pesquisa, as técnicas de coleta de dados utilizadas como fonte primária de dados foi a entrevista e o registro de tempo (alinhado à entrevista), sendo a fonte secundária de dados a análise de documentos. Vale ressaltar que, de acordo com Sampieri et al (2006), antes da efetiva coleta de dados, é necessário fazer uma imersão inicial no campo a ser pesquisado, observando-se a necessidade de autorização específica ou a adequação do ambiente para obtenção dos dados, tendo sido necessário, para o 
desenvolvimento desse trabalho, a elaboração de um documento, solicitando autorização para a coleta de dados nos órgãos envolvidos.

O documento de requisição para realização da pesquisa foi protocolado nos seguintes órgãos: Ministério da Saúde (MS), Controladoria Geral da União (CGU), Tribunal de Contas da União (TCU), Secretaria do Tesouro Nacional (STN) e Fundo Nacional de Desenvolvimento da Educação (FNDE). Destes, apenas o FNDE não respondeu a solicitação, que acabou sendo excluído do estudo, tendo todos os outros órgãos deferido o pedido.

Os usos das técnicas de coleta de dados foram alinhados aos objetivos específicos, conforme descrito nos Quadros 5, 6, 7 e 8 que evidenciam a relação entre o objetivo específico, as técnicas utilizadas, os itens, tais como as questões ou os aspectos observados, e a motivação para o uso da técnica, evidenciando o porquê da utilização da técnica. Para o primeiro objetivo específico, foram obtidos dados a partir de duas fontes, conforme Erro! Fonte de referência não encontrada.5.

A técnica de análise documental utilizada, no primeiro objetivo específico, além de ter auxiliado na compreensão da estrutura do órgão, auxiliou, em um primeiro momento, a ter contato com o tema. Conforme prevê Marconi e Lakatos (2010), essa técnica coloca o pesquisador em contato com o assunto abordado, propiciando a abordagem do tema sob um novo enfoque e pode abranger documentos oficiais, publicações administrativas e documentos particulares pertencentes aos envolvidos no processo, entre outros documentos.

Levando-se em consideração os participantes da pesquisa e com a finalidade de consolidar e obter o máximo de informações, por meio de um único roteiro, os dados relacionados à técnica de registro de tempo foram obtidos por meio do questionário aplicado para atingir o objetivo específico $\mathrm{n}^{\circ} 1$, conforme o Quadro 5. 
Quadro 5 - Técnicas de coleta de dados referente ao objetivo específico ${ }^{\circ} 01$

\begin{tabular}{|c|c|c|c|}
\hline \multicolumn{4}{|c|}{$\begin{array}{c}\text { OBJETIVO ESPECÍFICO N }{ }^{\circ} 1 \\
\text { MAPEAR O PROCESSO DE TCE, EM ESTUDO DE CASO NO FNS }\end{array}$} \\
\hline $\begin{array}{l}\text { Técnica de } \\
\text { coleta de dados }\end{array}$ & & Itens & Motivação \\
\hline $\begin{array}{l}\text { Análise de } \\
\text { documentos } \\
\text { institucionais }\end{array}$ & $\begin{array}{l}\text { - Relatório de Gestão } 2 \\
\text { - Regimento Interno do }\end{array}$ & $\begin{array}{l}\text { 13, } 2014 \text { e } 2015 \\
\text { Ministério da Saúde }\end{array}$ & $\begin{array}{l}\text { Compreender a } \\
\text { estrutura do órgão } \\
\text { para subsidiar na } \\
\text { elaboração do } \\
\text { mapeamento; }\end{array}$ \\
\hline \multirow{7}{*}{$\begin{array}{l}\text { Entrevista com } \\
\text { roteiro } \\
\text { semiestruturado }\end{array}$} & Categorias & Questões & \multirow{9}{*}{$\begin{array}{l}\text { - Identificar } \\
\text { estrutura regimental } \\
\text { e a abrangência que } \\
\text { está inserido o } \\
\text { processo; } \\
\text { - Identificar e inferir } \\
\text { como se processa as } \\
\text { atividades; } \\
\text { - Identificar a } \\
\text { quantidade de } \\
\text { atividades que o } \\
\text { profissional está } \\
\text { envolvido, e alinhar } \\
\text { essas informações } \\
\text { ao tempo dedicado } \\
\text { para aplicação do } \\
\text { modelo TDABC; } \\
\text { - Identificar as } \\
\text { principais atividades } \\
\text { de TCE, para } \\
\text { elaboração do do } \\
\text { mapeamento de } \\
\text { processo; } \\
\text { - Identificar o tempo } \\
\text { de cada atividade } \\
\text { informada para } \\
\text { aplicação do modelo } \\
\text { TDABC; } \\
\text { - Identificar a } \\
\text { possibilidade dentificar a } \\
\text { execução de registro } \\
\text { das atividades por } \\
\text { meio do check-list; } \\
\text { - Identificar o tempo } \\
\text { total dispendido na } \\
\text { administração para } \\
\text { aplicação do modelo } \\
\text { TDABC; integração entre os } \\
\text { sistemas. }\end{array}$} \\
\hline & IDENTIFICAÇÃO & $\begin{array}{l}\text { 1. Qual o seu nome, cargo e as } \\
\text { competências atribuídas nesse cargo? } \\
\text { 2. Qual o tempo de atuação na } \\
\text { organização e com processos de TCE? }\end{array}$ & \\
\hline & $\begin{array}{l}\text { ESTRUTURA } \\
\text { REGIMENTAL }\end{array}$ & $\begin{array}{ll}\text { 3. } & \text { Quais os setores que o processo de } \\
\text { TCE envolve? } & \\
\text { 4. } & \begin{array}{l}\text { Quais unidades da federação analisam } \\
\text { os processos de TCE? }\end{array}\end{array}$ & \\
\hline & PESSOAL & $\begin{array}{l}\text { 5. Qual o número de servidores que } \\
\text { atuam no processo de TCE? }\end{array}$ & \\
\hline & $\begin{array}{l}\text { MAPEAMENTO DO } \\
\text { PROCESSO DE TCE }\end{array}$ & $\begin{array}{l}\text { 6. Quais as etapas do trabalho para a } \\
\text { instauração da TCE? }\end{array}$ & \\
\hline & ATIVIDADES & $\begin{array}{l}\text { 7. Trabalha apenas com processos de } \\
\text { TCE? } \\
\text { 8. Quais as principais atividades que } \\
\text { envolvem os processos de TCE? } \\
\text { 9. } \begin{array}{l}\text { Quais as atividades secundárias que } \\
\text { envolvem os processos de TCE? }\end{array}\end{array}$ & \\
\hline & TEMPO & $\begin{array}{l}\text { 10. Qual o tempo médio que é gasto em } \\
\text { cada atividade que envolve TCE? } \\
\text { 11. Qual o percentual de tempo gasto em } \\
\text { cada atividade que envolve TCE? } \\
\text { 12. Qual a carga horária diária e semanal a } \\
\text { ser cumprida? }\end{array}$ & \\
\hline \multirow[t]{2}{*}{$\begin{array}{l}\text { Entrevista com } \\
\text { roteiro } \\
\text { semiestruturado }\end{array}$} & CONFIABILIDADE & $\begin{array}{l}\text { 13. Qual a sua opinião caso seja necessário } \\
\text { realizar o registro do tempo de cada } \\
\text { atividade a partir de um check-list de } \\
\text { atividades? } \\
\text { 14. Qual a sua opinião caso o SISTCE } \\
\text { mensure o tempo gasto de cada } \\
\text { atividade, para posterior cálculo e } \\
\text { cobrança do valor do custo do } \\
\text { processo? } \\
\text { Além das duas possibilidades acima, } \\
\text { como sugere que seja feita a } \\
\text { mensuração do tempo gasto do } \\
\text { processo de TCE? }\end{array}$ & \\
\hline & SISTEMA & $\begin{array}{l}\text { 16. Considera viável fazer a integração do } \\
\text { SISTCE com o Sistema de } \\
\text { Informações de Custos do Governo } \\
\text { Federal? }\end{array}$ & \\
\hline
\end{tabular}

Fonte: Elaborado pela autora. 
Para Nakagawa (2001, p. 72), a técnica de registro de tempo não é fácil de se instituir, por ser trabalhoso e sem tradição, devendo ser alinhado às entrevistas que subsidiarão a obtenção dos dados, a fim de organizar uma matriz com o tempo gasto em cada atividade.

De acordo com Kaplan e Anderson (2003), para a aplicação do método de custeio TDABC, a obtenção das informações acerca dos custos e recursos atribuídos a uma atividade podem ser determinadas por meio de técnicas de entrevistas e registros de tempo, relacionada à percentagem de tempo que as pessoas gastam nas diversas atividades. Portanto, essas técnicas foram utilizadas para atingir o objetivo específico $\mathrm{n}^{\circ}$ 02, conforme descrito no Quadro 6.

Para o objetivo específico $\mathrm{n}^{\mathrm{o}} 3$, a técnica de coleta de dados utilizada foi a entrevista norteada por um roteiro semiestruturado, conforme descrito no Erro! Fonte de referência não encontrada. 7.

Apesar de ser mais demorada e dispendiosa, a entrevista é a técnica de coleta de dados mais importante, sendo conduzida na forma de diálogo, devendo o entrevistador estar preparado quanto às informações básicas a respeito das atividades relevantes do departamento, conforme afirma Nakagawa (2001).

Para atingir o objetivo específico $\mathrm{n}^{\circ} 3$, há contribuições do roteiro de entrevista elaborado para o primeiro objetivo específico, tendo em vista que foram levados em consideração os participantes da pesquisa e a finalidade de consolidar e obter o máximo de informações por meio de um único roteiro.

Para o objetivo específico $\mathrm{n}^{\circ} 4$ também foi utilizada exclusivamente a entrevista como coleta de dados, conforme Erro! Fonte de referência não encontrada.8. 
Quadro 6 - Técnicas de coleta de dados referente ao objetivo específico n ${ }^{\circ} 02$

\begin{tabular}{|c|c|c|c|}
\hline \multicolumn{4}{|c|}{$\begin{array}{c}\text { OBJETIVO ESPECÍFICO N² } \\
\text { APURAR O CUSTO DO PROCESSO DE TCE, UTILIZANDO O MÉTODO TDBAC }\end{array}$} \\
\hline $\begin{array}{c}\text { Técnica de } \\
\text { coleta de dados }\end{array}$ & & Itens & Motivação \\
\hline \multirow{3}{*}{$\begin{array}{l}\text { ntrevista com } \\
\text { roteiro } \\
\text { semiestruturado }\end{array}$} & Categorias & Questões & \multirow{3}{*}{$\begin{array}{l}\text { - Identificar os dados } \\
\text { referentes ao custo } \\
\text { envolvidos no processo e } \\
\text { para o desempenho das } \\
\text { atividades de TCE, para } \\
\text { aplicar no modelo } \\
\text { TDABC; }\end{array}$} \\
\hline & CUSTOS & $\begin{array}{l}\text { 1. Qual o tamanho do espaço disponível } \\
\text { para o desempenho das atividades de } \\
\text { análise dos processos de TCE? } \\
\text { 2. Qual a remuneração de todos os } \\
\text { colaboradores que trabalham com a } \\
\text { análise dos processos de TCE, nos } \\
\text { últimos } 12 \text { meses? } \\
\text { 3. Qual o valor gasto com materiais } \\
\text { administrativos e de expediente pelas } \\
\text { áreas que trabalham com TCE, nos } \\
\text { últimos } 12 \text { meses? } \\
\text { 4. Qual o valor gasto com serviços de } \\
\text { terceiros pelas áreas que trabalham } \\
\text { com processos de TCE, nos últimos } \\
\text { 12 meses? } \\
\text { 5. Qual o valor gasto com serviço de } \\
\text { manutenção pelas áreas que } \\
\text { trabalham com processos de TCE, } \\
\text { nos últimos } 12 \text { meses? } \\
\text { 6. Qual o valor gasto com telefonia } \\
\text { pelas áreas que trabalham com TCE, } \\
\text { nos últimos } 12 \text { meses? } \\
\text { 7. Qual o valor gasto com água pelas } \\
\text { áreas que trabalham com TCE, nos } \\
\text { últimos } 12 \text { meses? } \\
\text { 8. Qual o valor gasto com energia } \\
\text { elétrica pelas áreas que trabalham } \\
\text { com processos de TCE? } \\
\text { 9. Qual o valor gasto com } \\
\text { Aluguel/depreciação pelas áreas que } \\
\text { trabalham com processos de TCE, } \\
\text { nos últimos } 12 \text { meses? } \\
\text { 10. Qual o valor gasto com serviços de } \\
\text { informática pelas áreas que trabalham } \\
\text { com processos de TCE, nos últimos } \\
\text { 12 meses? }\end{array}$ & \\
\hline & CONFIABILIDADE & $\begin{array}{l}\text { 11. Qual o sistema de informação que } \\
\text { disponibiliza esses dados? } \\
\text { 12. Os dados estão disponíveis para } \\
\text { consulta pública? }\end{array}$ & \\
\hline $\begin{array}{l}\text { Registro de } \\
\text { tempo }\end{array}$ & \multicolumn{2}{|c|}{$\begin{array}{l}\text { - Dados obtidos por meio do questionário aplicado para o } \\
\text { Objetivo Específico } \mathrm{n}^{\mathbf{o}} 1 \text { - Questões } 11,12 \text { e } 13 \text {. }\end{array}$} & $\begin{array}{l}\text { - Obter os dados de } \\
\text { quantitativo e percentual } \\
\text { de tempo gasto em cada } \\
\text { atividade. }\end{array}$ \\
\hline
\end{tabular}

Fonte: Elaborado pela autora. 
Quadro 7 - Entrevista referente ao objetivo específico $n^{\circ} 03$

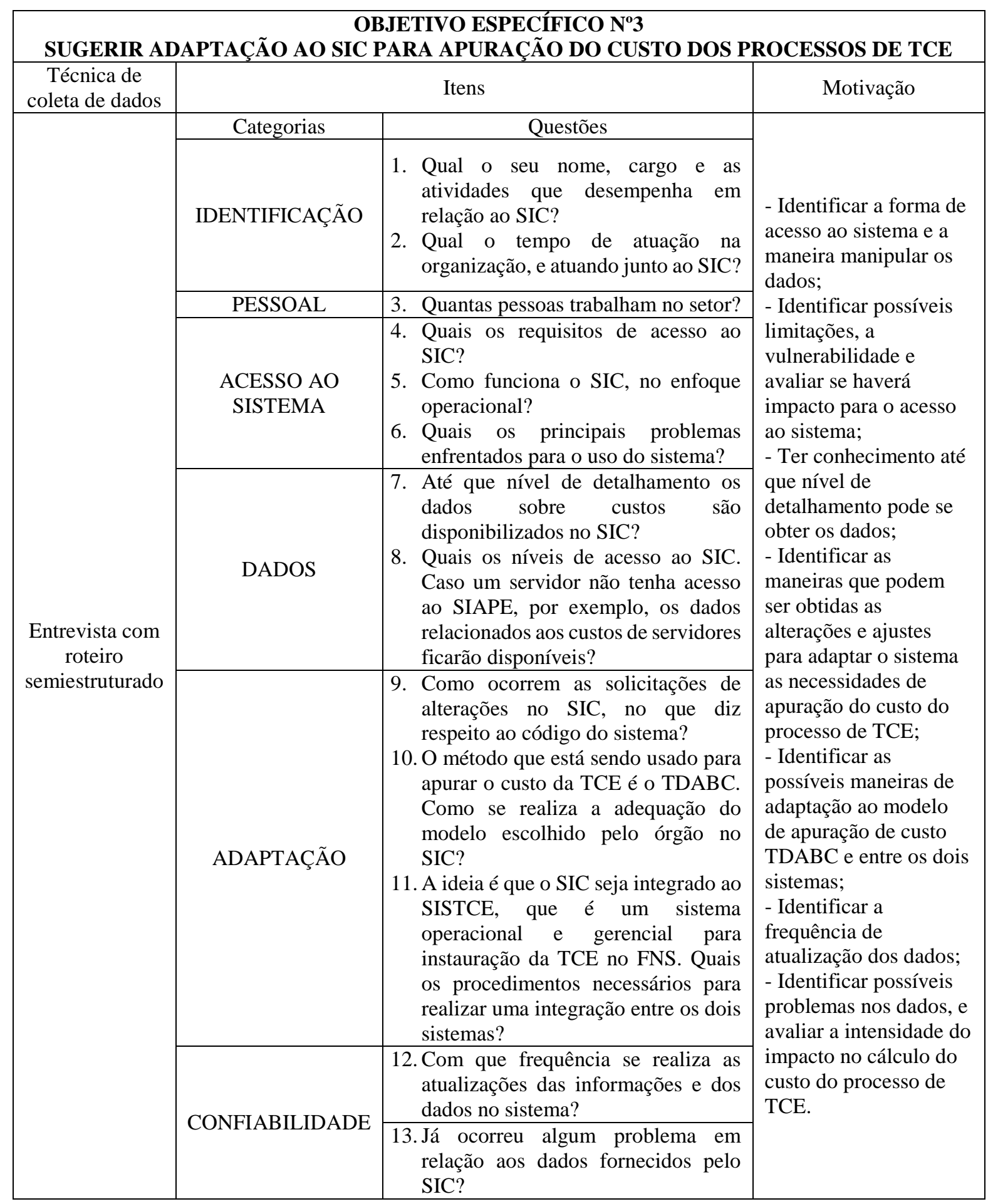

Fonte: Elaborado pela autora. 
Quadro 8 - Entrevista referente ao objetivo específico $n^{\text {o }} 04$

\begin{tabular}{|c|c|c|c|}
\hline \multicolumn{4}{|c|}{$\begin{array}{c}\text { OBJETIVO ESPECÍFICO N } \mathbf{N}^{\circ} \\
\text { PROPOR MEIOS QUE CONTRIBUAM PARA A ADMINISTRAÇÃO PÚBLICA OBTER O } \\
\text { REEMBOLSO DO VALOR GASTO NOS PROCESSOS DE TCE. }\end{array}$} \\
\hline $\begin{array}{c}\text { Técnica de } \\
\text { coleta de dados }\end{array}$ & & Itens & Motivação \\
\hline \multirow{7}{*}{$\begin{array}{l}\text { Entrevista com } \\
\quad \text { roteiro } \\
\text { semiestruturado }\end{array}$} & Categorias & Questões & \multirow{7}{*}{$\begin{array}{l}\text { - Verificar a pertinência da } \\
\text { cobrança do custo do } \\
\text { processo de TCE, para fins } \\
\text { de reembolso; } \\
\text { - Identificar os possíveis } \\
\text { motivos que impeçam de } \\
\text { dar continuidade à } \\
\text { cobrança do custo do } \\
\text { processo de TCE, e avaliar } \\
\text { quais os possíveis motivos; } \\
\text { - Identificar quais os meios } \\
\text { que podem ser usados para } \\
\text { normatizar e tornar eficaz } \\
\text { o início da cobrança. }\end{array}$} \\
\hline & IDENTIFICAÇÃO & $\begin{array}{l}\text { 1. Qual o seu nome, cargo e as } \\
\text { atribuições que desempenha em } \\
\text { relação a cobrança dos processos de } \\
\text { TCE? }\end{array}$ & \\
\hline & & $\begin{array}{l}\text { 2. Qual o tempo de atuação na } \\
\text { organização e com processos de } \\
\text { TCE? }\end{array}$ & \\
\hline & \multirow{3}{*}{ LEGITIMIDADE } & $\begin{array}{l}\text { 3. Considera pertinente a cobrança dos } \\
\text { valores referente ao custo } \\
\text { despendido pela Administração } \\
\text { Pública para instauração do } \\
\text { processo de TCE, que é uma medida } \\
\text { excepcional adotada pela } \\
\text { Administração? Justifique. }\end{array}$ & \\
\hline & & $\begin{array}{l}\text { 4. Considera que pode haver } \\
\text { questionamentos adversos em } \\
\text { relação a essa cobrança? Justifique. }\end{array}$ & \\
\hline & & $\begin{array}{l}\text { 5. Levando em consideração o aspecto } \\
\text { da apuração do valor, é suficiente } \\
\text { que seja realizada por meio de uma } \\
\text { metodologia, baseado em um } \\
\text { modelo que leva em consideração as } \\
\text { atividades e o tempo despendido } \\
\text { para instauração? Justifique. }\end{array}$ & \\
\hline & NORMATIZAÇÃO & $\begin{array}{l}\text { 6. Qual o instrumento normativo que } \\
\text { considera necessário para } \\
\text { estabelecer o início da cobrança? }\end{array}$ & \\
\hline
\end{tabular}

Fonte: Elaborado pela autora.

Para os quatro objetivos específicos desse trabalho, a principal técnica de obtenção de dados de fonte primária foram as entrevistas. Os roteiros utilizados em todas elas foram os semiestruturados, que "se baseia em um guia de assuntos ou questões e o pesquisador tem a liberdade de introduzir mais questões para a precisão de conceitos ou obter maiores informações sobre os temas desejados", conforme define Sampieri et al (2006, p. 381) e no qual "o entrevistador tem liberdade para desenvolver cada situação em qualquer direção que considere adequada" (MARCONI e LAKATOS, 2010, p. 180). 
As entrevistas foram aplicadas pela própria pesquisadora, no período de junho a agosto de 2016, que esclareceu as dúvidas durante a aplicação, minimizando os erros provenientes de falta de entendimento por parte dos entrevistados.

Cumpre mencionar ainda a consulta a 10 juízes - dentre professores da área de custos, especialistas, mestre e doutores - para que avaliassem as questões elaboradas, tendo havido a colaboração com críticas para melhorias de 3 destes. Esse retorno gerou adequações ao roteiro de entrevista inicialmente proposto, que, após os ajustes, resultou nos roteiros já apresentados e disponíveis nos Quadros 5, 6, 7 e 8.

Os critérios de avaliação, também validados pelos juízes, enfatizaram: clareza da linguagem, pertinência das perguntas e relevância teórica. No Apêndice A está disponível a versão inicial dos roteiros enviada aos juízes. No Apêndice B estão relacionadas as notas recebidas, acompanhada das respectivas médias e as observações, que contribuíram para reformular as questões do roteiro.

\subsection{CARACTERIZAÇÃO DO PERFIL ESPERADO E PARTICIPANTES DA PESQUISA}

A escolha dos participantes se deu em virtude do cargo que ocupam e a população do estudo compreendeu as unidades administrativas que participam do processo de Tomada de Contas Especial do MS, que são o FNS, a CGU, o TCU, o MPU-TCU e a AGU, e as setoriais de Custo dos órgãos envolvidos do próprio MS e da STN.

Para a seleção dos participantes, foi feita uma solicitação aos órgãos envolvidos no processo de TCE. O interesse da pesquisa foi direcionado às entrevistas com gestores que pudessem contribuir com informações acerca do processo de TCE, dos custos envolvidos, do SIC e do reembolso para a Administração Pública. 
Portanto, a seleção de gestores ocorreu a partir da disponibilidade do órgão e que estivessem aptos a emitir opinião sobre o assunto. Desta forma, a escolha foi não probabilística, que também pode ser chamada de amostra por conveniência, conforme afirma Sampieri et al (2006). Este é um procedimento de seleção informal, oferecendo ao pesquisador a opção de obter informações junto à população que mais interessa, possibilitando a oferta de maior riqueza de dados para fins de coleta e análise.

Dentre os vários tipos de seleção por conveniência, apresentados e definidos por Sampieri et al (2006), a que foi utilizada nessa pesquisa foi a de especialistas, que se mostra frequente em estudos qualitativos, tendo como objetivo principal obter hipóteses claras e concisas.

Nesse sentido, os Quadros 9, 10, 11 e 12 relacionam os participantes da pesquisa, alinhado a cada objetivo específico da pesquisa, e o perfil respectivo. Foi realizada a diferenciação do perfil entre analistas e gestores. Integram o segundo grupo apenas entrevistados com algum cargo em comissão e das funções de direção, chefia e assessoramento no órgão.

Quadro 9 - Participantes da pesquisa do objetivo específico ${ }^{\circ} 01$

\begin{tabular}{|c|c|c|c|}
\hline \multicolumn{4}{c|}{ ROTEIRO DE ENTREVISTA 01 - OBJETIVO ESPECÍFICO No1 } \\
\multicolumn{4}{|c|}{ MAPEAR O PROCESSO DE TCE EM ESTUDO DE CASO NO FNS } \\
\hline SIGLA & ÓRGÃO & Perfil & Tempo de atuação na TCE \\
\hline E1 & Fundo Nacional de Saúde (FNS) & Analista & 5 anos e 3 meses \\
\hline E2 & Fundo Nacional de Saúde (FNS) & Analista & 3 anos \\
\hline
\end{tabular}

Fonte: Elaborado pela autora.

Para o objetivo específico $\mathrm{n}^{\circ}$ 01, que é mapear o processo de TCE em estudo de caso no FNS, que serve de base para atingir também o objetivo específico $\mathrm{n}^{\circ} 02$, no que concerne ao tempo gasto nas atividades, foram escolhidos dois analistas do FNS, em decorrência do que requer a aplicação do modelo TDABC. Segundo Kaplan e Anderson (2007, p. 85): 
(...) a equipe de projeto entrevista dois ou três funcionários em cada departamento para identificar os processos críticos e atividades, os direcionadores responsáveis pelas variações no consumo de capacidade pelos objetos de custo (em geral tempo), e o tempo médio por passo.

São 6 os analistas da CCONT que lidam com tomadas de contas especiais.

Também houve contribuição para a obtenção dos dados para o objetivo específico $\mathrm{n}^{\circ} 03$, quanto à adaptação do SIC para a apuração do processo de TCE. Além disso, a pesquisadora desenvolveu a atividade tomadora de contas especial, junto a equipe de análise dos processos de Tomada de Contas Especial no Fundo Nacional de Saúde, com 5 anos de tempo de atuação nessa área, o que contribuiu para o mapeamento do processo de TCE dentro da unidade em estudo.

O segundo roteiro de entrevista serviu como base para obtenção dos dados para apuração do custo do processo de TCE usando o método TDABC. Para isso, foi necessário entrevistar alguém com perfil de acesso a dados e informações do SIAFI e SIC e que pudesse informar os custos envolvidos, conforme Quadro 10.

Quadro 10 - Participantes da pesquisa do objetivo específico $\mathrm{n}^{\circ} 02$

\begin{tabular}{|c|c|c|c|}
\hline \multicolumn{4}{|c|}{ ROTEIRO DE ENTREVISTA 02 - OBJETIVO ESPECÍFICO N² } \\
APURAR O CUSTO DO PROCESSO DE TCE, UTILIZANDO O MODELO TDABC \\
\hline SIGLA & ÓRGÃO & Perfil & Tempo de atuação na organização \\
\hline E3 & Ministério da Saúde (MS) & Analista & 5 anos e 9 meses \\
\hline
\end{tabular}

Fonte: Elaborado pela autora.

O terceiro roteiro de entrevista foi aplicado a um analista da setorial de custos do Ministério da Saúde, escolhido por ser o mais antigo, na equipe de três pessoas, e pela ausência de chefia lotada no cargo de coordenador na época da coleta de dados. Para o órgão da STN, órgão de custos central da Administração Pública, o gestor entrevistado foi o único disponibilizado para que a entrevista pudesse ser realizada, apesar de a equipe contar com 17 
pessoas, conforme informação coletada durante a entrevista. As informações referentes aos entrevistados pelo roteiro de entrevista $\mathrm{n}^{\circ} 03$ encontram-se no Quadro 11.

Quadro 11 - Participantes da pesquisa do objetivo específico ${ }^{\circ} 03$

\begin{tabular}{|c|c|c|c|}
\hline \multicolumn{4}{|c|}{ ROTEIRO DE ENTREVISTA O3 - OBJETIVO ESPECÍFICO No3 } \\
\multicolumn{4}{|c|}{ SUGERIR ADAPTAÇÃO AO SIC PARA APURAÇÃO DO CUSTO DOS PROCESSOS DE TCE } \\
\hline SIGLA & ÓRGÃO & Perfil & Tempo de atuação junto ao SIC \\
\hline E4 & Secretaria do Tesouro Nacional (STN) & Gestor & 5 anos e 3 meses \\
\hline E5 & Ministério da Saúde (MS) & Analista & 4 anos e 5 meses \\
\hline
\end{tabular}

Fonte: Elaborado pela autora.

$\mathrm{O}$ roteiro de entrevista $\mathrm{n}^{\circ} 04$ foi aplicado a um maior número de gestores e analistas e envolveu também um maior número de órgãos, já que se trata dos meios que possibilitem à Administração Pública obter o reembolso do valor gasto no processo de TCE. Portanto, era necessária a coleta da opinião dos órgãos envolvidos no processo, observados os mesmos critérios de seleção para os roteiros anteriores, conforme as informações disponíveis no Quadro 12.

A informação quanto ao tempo de dedicação à organização (para os objetivos específicos $\mathrm{n}^{\circ} 02$ e 04), ao SIC (para o objetivo específico $\mathrm{n}^{\circ}$ 03) ou às atividades de TCE (para o objetivo específico $\mathrm{n}^{\circ}$ 01) foram obtidas por meio das entrevistas. O tempo na organização refere-se ao tempo em que o gestor ou servidor encontra-se exercendo suas funções no órgão, enquanto o tempo de atuação junto ao SIC ou à TCE refere-se ao tempo em que os entrevistados se dedicam a essas atividades específicas, independentemente do tempo de serviço na organização. 
Quadro 12 - Participantes da pesquisa do objetivo específico no 04

\begin{tabular}{|}
$\mid$\begin{tabular}{c}
\hline \multicolumn{5}{|c|}{ ROTEIRO DE ENTREVISTA 04 - OBJETIVO ESPECÍFICO No4 } \\
PROPOR MEIOS QUE POSSIBILITE A ADMINISTRAÇÃO PÚBLICA O REEMBOLSO DO \\
VALOR GASTO NOS PROCESSOS DE TCE
\end{tabular} \\
\hline SIGLA & ÓRGÃO & Perfil & Tempo de atuação na organização \\
\hline E6 & Fundo Nacional de Saúde (FNS) & Gestor & 11 anos \\
\hline E7 & Fundo Nacional de Saúde (FNS) & Gestor & 9 anos \\
\hline E8 & Fundo Nacional de Saúde (FNS) & Analista & 5 anos e 3 meses \\
\hline E9 & Fundo Nacional de Saúde (FNS) & Analista & 5 anos \\
\hline E10 & Controladoria Geral da União (CGU) & Gestor & 13 anos \\
\hline E11 & Advocacia Geral da União (AGU) & Gestor & 17 anos \\
\hline E12 & Advocacia Geral da União (AGU) & Gestor & 10 anos \\
\hline E13 & Advocacia Geral da União (AGU) & Gestor & 8 anos \\
\hline E14 & Tribunal de Contas da União (TCU) & Gestor & 22 anos \\
\hline E15 & Tribunal de Contas da União (TCU) & Gestor & 22 anos \\
\hline E16 & $\begin{array}{c}\text { Ministério Público junto ao Tribunal de Contas da } \\
\text { União (MP-TCU) }\end{array}$ & Gestor & 20 anos \\
\hline E17 & Ministério Público junto ao Tribunal de Contas da \\
União (MP-TCU) & Analista & 24 anos \\
\hline
\end{tabular}

Fonte: Elaborado pela autora.

\subsection{ANÁLISE E TRATAMENTO DOS DADOS}

Após a obtenção dos dados, a análise foi realizada seguindo as orientações previstas por Sampieri et al (2006) quais sejam: revisar o material coletado, estabelecer um plano de trabalho inicial, codificar os dados em um primeiro nível, codificar os dados em um segundo nível, interpretar os dados, descrever o contexto, assegurar a confiabilidade e a validade dos dados.

Para se alcançar os objetivos desse trabalho, para o tratamento dos dados obtidos foi realizada a análise de conteúdo, que para Bardin (2011) é um conjunto de técnicas de análise de comunicação, que utiliza procedimentos pré-estabelecidos, com fins de descrição de conteúdo de mensagem para viabilizar a sua inferência, sendo a categorização parte desse procedimento.

De acordo com Bardin (2011, p. 147), “a divisão das componentes das mensagens analisadas em rubricas ou categorias não é uma etapa obrigatória de toda e qualquer análise de conteúdo. A maioria dos procedimentos de análise organiza-se, no entanto, em redor de um processo de categorização". Em contraponto, Ludwig (2009) afirma que é imprescindível que 
o pesquisador faça uso de categorias na fase de análise dos dados, ao utilizar o método de estudo de caso, categorias estas, resultantes de enquadramentos teóricos obtidos na literatura

Nesses moldes, esse trabalho utilizou um processo de categorização para estruturar o desenvolvimento dessa dissertação, a partir dos objetivos específicos, para elaborar o roteiro semiestruturado para as entrevistas e para realizar a análise de conteúdo das entrevistas.

As categorias foram correlacionadas aos objetivos específicos, conforme apresentado no Quadro 13, alinhado ainda à forma do tratamento dos dados.

Quadro 13 - Categorias correlacionadas aos objetivos específicos

\begin{tabular}{|ll|c|c|}
\hline \multicolumn{1}{|c|}{ OBJETIVO ESPECÍFICO } & CATEGORIAS & TRATAMENTO DOS DADOS \\
\hline $\begin{array}{l}\text { Mapear o processo de TCE, em estudo de caso } \\
\text { no FNS; }\end{array}$ & $\begin{array}{c}\text { Processo de } \\
\text { TCE }\end{array}$ & $\begin{array}{c}\text { Análise de conteúdo e método de } \\
\text { custeio TDABC }\end{array}$ \\
\hline $\begin{array}{l}\text { Apurar o custo do processo de TCE, utilizando o } \\
\text { modelo TDABC }\end{array}$ & $\begin{array}{c}\text { Análise de conteúdo e método de } \\
\text { custeio TDABC }\end{array}$ \\
\hline $\begin{array}{l}\text { Sugerir adaptação ao SIC para apuração do custo } \\
\text { dos processos de TCE }\end{array}$ & $\begin{array}{c}\text { Sistema de } \\
\text { Custos }\end{array}$ & Análise de conteúdo \\
\hline 4. & $\begin{array}{l}\text { Propor meios que possibilite a Administração } \\
\text { Pública o reembolso do valor gasto nos } \\
\text { processos de TCE }\end{array}$ & Reembolso & Anteúdo \\
\hline
\end{tabular}

Fonte: Elaborado pela autora.

Em relação à aplicação do modelo de apuração de custos TDABC, os procedimentos metodológicos utilizados neste estudo seguiram uma rotina aderente aos conceitos e fundamentos do modelo, tendo em vista que o objetivo foi apurar o custo do processo de TCE, que representa um objeto de custo dentro de um departamento que desenvolve outras atividades, visando ao reembolso deste custo.

Para gerar as categorias necessárias à análise de conteúdo das entrevistas, foi utilizada a sequência de análise da entrevista orientada por Bardin (2011), que considera: a análise temática; características associadas ao tema central; análise sequencial; análise da enunciação; e esqueleto da entrevista. 
Quanto ao mapeamento do processo de TCE, a ilustração foi realizada no sistema Bizagi Modeler Versão 3.0.0.022 e as orientações para a modelagem são de Capote (2011), conforme a legenda apresentada na Figura 4.

\subsection{EXPECTATIVAS DE RESULTADOS}

As principais expectativas que se espera obter, e que devem ser debatidas nesse trabalho, estão vinculadas aos respectivos objetivos específicos, quais sejam:

- O mapeamento já existente no FNS não atende a aplicação do método de custeio TDABC na apuração do custo das TCEs;

- O TDABC é a metodologia adequada para apuração do custo do processo de TCE;

- O SIC é um sistema de custo adequado para apuração do custo do processo de TCE;

- Faltam normas que incentivem a apuração e o reembolso do custo do processo de TCE.

O Quadro 14, a seguir, revisa e sintetiza os principais itens metodológicos da pesquisa. 
Quadro 14 - Quadro resumo da metodologia de estudo

\begin{tabular}{|c|c|c|c|c|}
\hline Problema de pesquisa: & \multicolumn{4}{|c|}{ Como obter o reembolso do custo do processo de TCE, sendo este calculado por meio do SIC? } \\
\hline Objetivo Geral: & \multicolumn{4}{|c|}{ Identificar meios de obtenção do reembolso para a Administração Pública do custo do processo da TCE. } \\
\hline Objetivos Específicos: & $\begin{array}{l}\text { 1. Mapear as atividades do } \\
\text { processo de TCE, em estudo } \\
\text { de caso no FNS }\end{array}$ & $\begin{array}{l}\text { 2. Apurar o custo do processo } \\
\text { de TCE, utilizando o modelo } \\
\text { TDABC }\end{array}$ & $\begin{array}{l}\text { 3. Sugerir adaptação ao SIC } \\
\text { para apuração do custo dos } \\
\text { processos de TCE }\end{array}$ & $\begin{array}{lr}\text { 4. Propor meios que } \\
\text { contribuam para a } \\
\text { Administração Pública obter o } \\
\text { reembolso do valor gasto nos } \\
\text { processos de TCE }\end{array}$ \\
\hline \multicolumn{5}{|c|}{ Operacionalização da pesquisa de acordo com os objetivos específicos } \\
\hline Principais Autores & $\begin{array}{l}\text { Fernandes (2015); Quintão; } \\
\text { Carneiro (2015); Silva } \\
\text { (2010); Documentos } \\
\text { institucionais. }\end{array}$ & $\begin{array}{c}\text { Alonso (1999); Martins } \\
\text { (2003); Kaplan; Anderson } \\
\text { (2007); Evereart et al (2008); } \\
\text { Pernot, Roodhooft e Van Den } \\
\text { Abbeele (2007). }\end{array}$ & $\begin{array}{l}\text { Holanda, Lattman-Weltman e } \\
\text { Guimarães (2010); Machado } \\
\text { (2005); Suzart (2012); } \\
\text { Machado; Holanda (2010); } \\
\text { Silva (2011). }\end{array}$ & $\begin{array}{l}\text { Sánchez-Martínez (2006); } \\
\text { Schreyögg (2006); Lee et } \\
\text { al. (2015); Vogl (2012); } \\
\text { FASB (1995); Lee; Salone } \\
\text { (2014). }\end{array}$ \\
\hline Tipo de pesquisa & Descritiva e Qualitativa & Descritiva e Qualitativa & Descritiva e Qualitativa & Descritiva e Qualitativa \\
\hline Participantes da pesquisa & $\begin{array}{l}\text { Setores do FNS envolvidos } \\
\text { no processo de TCE }\end{array}$ & $\begin{array}{c}\text { Setores do MS detentores das } \\
\text { informações acerca dos } \\
\text { custos }\end{array}$ & $\begin{array}{c}\text { Setorial de Custos do MS e } \\
\text { STN }\end{array}$ & $\begin{array}{c}\text { Órgãos envolvidos no } \\
\text { processo de TCE, sendo o } \\
\text { FNS, CGU, TCU, MP-TCU e } \\
\text { AGU) }\end{array}$ \\
\hline Técnica de análise dos dados & $\begin{array}{c}\text { Análise de conteúdo; método } \\
\text { de Custeio TDABC }\end{array}$ & $\begin{array}{c}\text { Análise de conteúdo; método } \\
\text { de Custeio TDABC }\end{array}$ & Análise de conteúdo & Análise de conteúdo \\
\hline Categorias & $\begin{array}{l}\text { Atividades do processo de } \\
\text { TCE }\end{array}$ & Custo & Sistema de Custos & Reembolso \\
\hline Expectativas de resultados & $\begin{array}{c}\text { H1 - O mapeamento já } \\
\text { existente no FNS não atende } \\
\text { a aplicação do método de } \\
\text { custeio TDABC na apuração } \\
\text { do custo das TCEs. }\end{array}$ & $\begin{array}{l}\mathrm{H} 2-\mathrm{O} \text { TDABC é } \\
\text { metodologia adequada para } \\
\text { apuração do custo do } \\
\text { processo de TCE. }\end{array}$ & $\begin{array}{l}\text { H3 - O SIC é um sistema de } \\
\text { custo adequado para apuração } \\
\text { do custo do processo de TCE. }\end{array}$ & $\begin{array}{l}\mathrm{H} 4 \text { - Faltam normas que } \\
\text { incentivem a apuração e o } \\
\text { reembolso do custo do } \\
\text { processo de TCE. }\end{array}$ \\
\hline
\end{tabular}

Fonte: Elaborado pela autora. 


\section{DESCRIÇÃO E ANÁLISE DOS DADOS}

Esse capítulo está dividido por objetivo específico e descreve e analisa os achados encontrados durante a pesquisa.

\subsection{MAPEAMENTO DO PROCESSO DE TCE NO FNS}

Para uma clara apuração de custos, é necessário ter a visão de processos, pois possibilitará analisar com clareza se a necessidade dos administradores está voltada às atividades (meios) ou às soluções produzidas (fins), no que se refere aos serviços públicos (SILVA, 2011).

Em consulta ao FNS, foi identificado que existem dois mapeamentos de processo, tendo um deles sido elaborado para atender a área de informática, para fins de desenvolvimento do sistema, e um outro que foi demandado pela Secretaria Executiva do MS, sem ter sido informada a finalidade. Porém, os dois mapeamentos disponíveis envolvem as outras atividades que a CCONT/FNS desenvolve, não sendo exclusivos do processo de TCE e, portanto, não atendem na íntegra do objetivo deste trabalho. Assim, é necessária a elaboração de um mapeamento de processo específico para a TCE e que dê suporte para a aplicação do método de custeio TDABC.

Para a elaboração do mapeamento de processo, além de consultar os fluxos de processos já existentes no órgão, foi realizada a consulta também ao relatório de gestão do FNS, as quais, junto com as informações coletadas nas entrevistas, viabilizaram a elaboração da Figura 4, que ilustra exclusivamente as etapas do fluxo do processo de TCE na CCONT/FNS, correspondente a etapa 2 da Figura 2. 
Figura 4 - Mapeamento do processo de TCE na CCONT/FNS

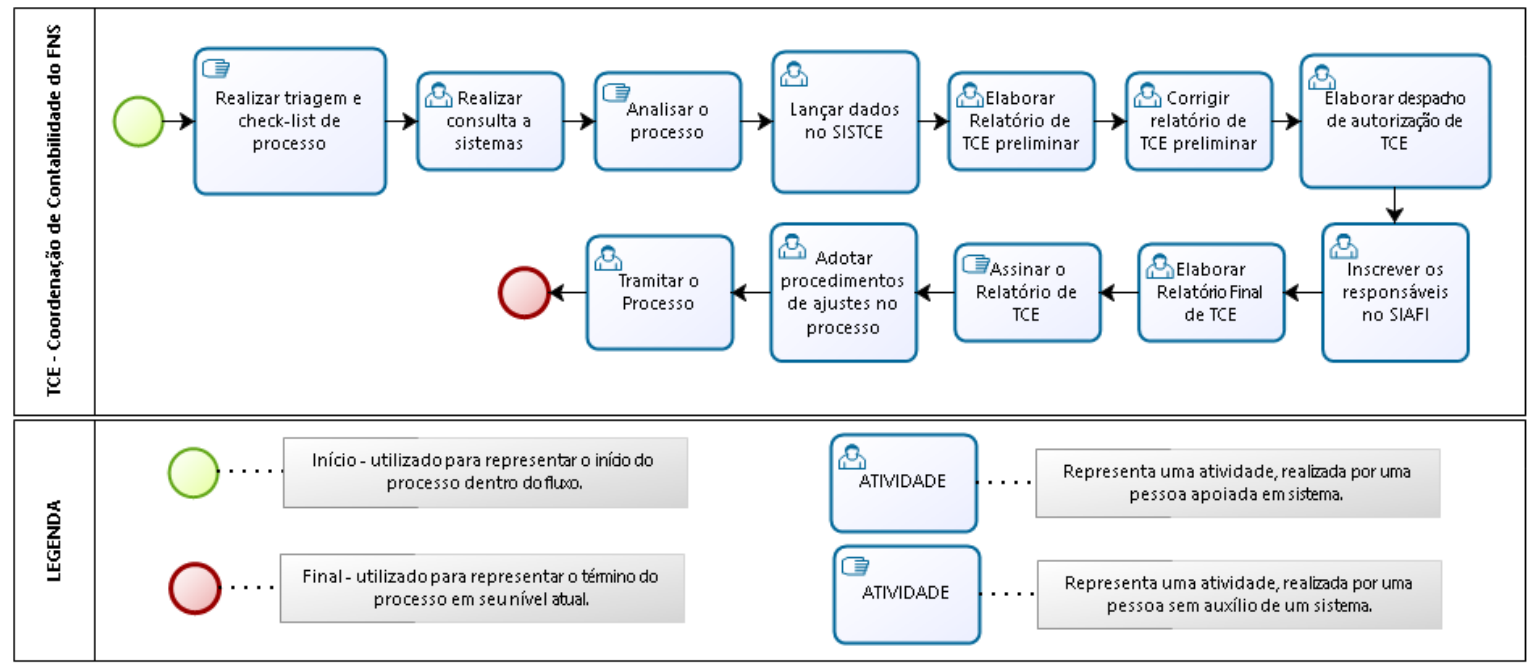

Fonte: Elaborado pela autora

Não houve registro das exceções que ocorrem, como no caso quando há o retorno do processo às áreas de origem para ajustes, bem como não se considerou as atividades que não são vinculadas a TCE, tais como de recursos humanos, financeiro e alta gestão. Assim, essas são as restrições da apuração do custo.

\subsection{APURAÇÃO DO CUSTO DO PROCESSO DE TCE PELO MODELO TDABC}

Para a apuração do custo do processo de TCE foi necessário mapear as atividades dos setores envolvidos e realizar a aplicação do modelo TDABC, sendo que este exige o cumprimento dos seguintes passos, de acordo com a inferência obtida a partir de Everaert e Bruggeman (2007), Everaert et al (2008), Silva et al (2011) e Carraro e Allgaier (2015):

- $1^{\circ}$ PASSO: identificação das atividades que são realizadas, de acordo com as informações que foram obtidas a partir do mapeamento do processo, nos moldes para se atingir o objetivo específico $\mathrm{n}^{\circ} 01$; 
- $2^{\circ}$ PASSO: realizar o levantamento dos objetos de gastos do setor;

- $3^{\circ}$ PASSO: estimativa da capacidade prática do setor, obtendo o tempo total dedicado à execução das atividades;

- $4^{\circ}$ PASSO: cálculo da unidade de tempo;

- $5^{\circ}$ PASSO: estabelecimento da unidade de tempo despendido em cada atividade;

- $6^{\circ}$ PASSO: cálculo do processo e obtenção do valor do processo de TCE.

Os dados que subsidiaram o cumprimento dos passos e a apuração do custo do processo de TCE são provenientes dos instrumentos de pesquisa utilizados, como a entrevista e o registro de tempo.

\subsection{1. $1^{\circ}$ Passo: Identificação das Atividades Realizadas}

Inicialmente foram identificadas 12 atividades relevantes no processo de instauração de TCE, no âmbito da CCONT/FNS, distribuídas entre três divisões envolvidas no ciclo de instauração, incluindo a CCONT/FNS, DITCE e SETCE. O Quadro 15 evidencia de forma sintética a descrição dessas atividades.

A disposição apresentada no Erro! Fonte de referência não encontrada.15 segue de acordo com o agrupamento dos centros de custo e não da sequência da ocorrência das atividades, já apresentada na Figura 4.

\subsection{2. $2^{\circ}$ Passo: Realizar o Levantamento dos Objetos de Gastos do Setor}

A Tabela 2 evidencia o levantamento dos objetos de gastos do setor responsável pela instauração do processo de TCE, que é a CCONT/FNS, e são referentes aos gastos diretos e indiretos. 
Quadro 15 - Descrição geral de atividades

\begin{tabular}{|c|c|c|}
\hline $\begin{array}{l}\text { CENTRO } \\
\text { DE CUSTOS }\end{array}$ & ATIVIDADES & DESCRIÇÃO DAS ATIVIDADES \\
\hline $\begin{array}{l}\text { CCONT/ } \\
\text { FNS }\end{array}$ & \multirow{3}{*}{$\begin{array}{l}\text { Assinar o Relatório } \\
\text { de TCE. }\end{array}$} & \multirow{3}{*}{$\begin{array}{l}\text { Coordena as atividades e auxilia os analistas em todo o processo de } \\
\text { desenvolvimento da TCE, culminando na assinatura dos relatórios de } \\
\text { TCE. }\end{array}$} \\
\hline DITCE & & \\
\hline SETCE & & \\
\hline \multirow{2}{*}{$\begin{array}{l}\text { SETCE/ } \\
\text { TCE }\end{array}$} & $\begin{array}{l}\text { Realizar triagem e } \\
\text { check-list do } \\
\text { processo }\end{array}$ & $\begin{array}{l}\text { Realizar uma análise prévia, com preenchimento do check-list para } \\
\text { verificar se contém todos os documentos necessários para realizar a } \\
\text { análise. }\end{array}$ \\
\hline & $\begin{array}{l}\text { Realizar consulta a } \\
\text { sistemas }\end{array}$ & $\begin{array}{l}\text { Realizar a consulta ao SIAFI, para verificar possíveis } \\
\text { ressarcimentos, e consulta de dados básicos dos responsáveis. }\end{array}$ \\
\hline \multirow{7}{*}{$\begin{array}{l}\text { SETCE/ } \\
\text { TCE }\end{array}$} & Analisar processo & $\begin{array}{l}\text { Analisar as informações contidas nos processos verificando os } \\
\text { elementos fáticos e jurídicos existentes e nexo de causalidade. }\end{array}$ \\
\hline & $\begin{array}{l}\text { Lançar dados no } \\
\text { SISTCE }\end{array}$ & $\begin{array}{l}\text { Lançar os registros no SISTCE das informações contidas nos } \\
\text { processos, tais como valores e dados dos responsáveis. }\end{array}$ \\
\hline & $\begin{array}{l}\text { Elaborar Relatório de } \\
\text { TCE Preliminar }\end{array}$ & $\begin{array}{l}\text { Elaboração de um relatório de TCE preliminar a partir das } \\
\text { informações contidas no processo. }\end{array}$ \\
\hline & $\begin{array}{l}\text { Elaborar despacho de } \\
\text { autorização de TCE }\end{array}$ & $\begin{array}{l}\text { Elaborar um despacho com a solicitação de autorização da } \\
\text { instauração da TCE, sendo assinado pelas chefias. }\end{array}$ \\
\hline & $\begin{array}{l}\text { Inscrever os } \\
\text { responsáveis no } \\
\text { SIAFI }\end{array}$ & $\begin{array}{c}\text { Registrar as informações contábeis no SIAFI quanto ao débito dos } \\
\text { responsáveis envolvidos no processo. }\end{array}$ \\
\hline & $\begin{array}{l}\text { Elaborar Relatório } \\
\text { Final de TCE }\end{array}$ & $\begin{array}{c}\text { Efetua os ajustes no relatório preliminar, insere as informações } \\
\text { acerca da autorização e inscrição de responsabilidade, } \\
\text { transformando-o em relatório final. }\end{array}$ \\
\hline & $\begin{array}{l}\text { Adotar } \\
\text { procedimentos de } \\
\text { ajustes no processo }\end{array}$ & $\begin{array}{l}\text { Adotar os procedimentos exigidos para tramitação do processo } \\
\text { físico, como inserir o número de páginas, carimbado e assinando, } \\
\text { carimbar em branco nas folhas sem informações, organizar e conferir } \\
\text { as condições gerais do processo. }\end{array}$ \\
\hline $\begin{array}{l}\text { SETCE/ } \\
\text { CORR }\end{array}$ & $\begin{array}{l}\text { Corrigir Relatório } \\
\text { Preliminar }\end{array}$ & $\begin{array}{l}\text { Efetua a correção do Relatório Preliminar para conferir se realmente } \\
\text { há todos os pressupostos para a instauração da TCE, e sanar } \\
\text { eventuais erros. }\end{array}$ \\
\hline $\begin{array}{l}\text { CCONT/ } \\
\text { ADM }\end{array}$ & Tramitar o Processo & $\begin{array}{c}\text { Atividade de conferência dos requisitos de adequação processual e } \\
\text { remessa a outra área que enviará o processo à CGU. }\end{array}$ \\
\hline
\end{tabular}

Fonte: Elaborado pela autora, com base nas informações obtidas nas entrevistas.

Tabela 2 - Objetos de gastos

\begin{tabular}{c|cc|c}
\hline OBJETO DE GASTOS & \multicolumn{2}{|c|}{ VALOR MÉDIO MENSAL } & \% \\
\hline Colaboradores & $\mathrm{R} \$$ & $201.616,97$ & $90,10 \%$ \\
Materiais administrativos e de expediente & $\mathrm{R} \$$ & $1.525,00$ & $0,68 \%$ \\
Serviços de terceiros & $\mathrm{R} \$$ & $7.455,38$ & $3,33 \%$ \\
Telefonia & $\mathrm{R} \$$ & 811,55 & $0,36 \%$ \\
Água & $\mathrm{R} \$$ & 489,51 & $0,22 \%$ \\
Energia elétrica & $\mathrm{R} \$$ & $4.982,83$ & $2,23 \%$ \\
Aluguel /depreciação & $\mathrm{R} \$$ & $6.891,33$ & $3,08 \%$ \\
\hline TOTAL & R\$ & $\mathbf{2 2 3 . 7 7 2 , 5 7}$ & $\mathbf{1 0 0 , 0 0 \%}$ \\
\hline
\end{tabular}


Fonte: Elaborado pela autora.

Todos os dados referem-se à média de 6 meses, entre os dias 01/01/2016 até 30/06/2016, e as planilhas de apuração dos valores médios mensais dos objetos de gastos do setor encontram-se no Apêndice C.

Os valores monetários considerados para a apuração relacionados a serviços de terceiros, telefonia, água, energia elétrica, aluguel/depreciação, conforme informações obtidas a partir do Entrevistado 3, são valores líquidos, após a retenção e recolhimento de tributos na fonte. Adverte-se também que "a busca desses dados no SIAFI foi feita a partir de levantamento (pesquisa sintética) de contratos" - ou seja, "é possível haver, por exemplo, contratos cujos objetos sejam serviços de terceirização, que não foram inclusos na pesquisa de ordem bancária no SIAFI".

Os colaboradores da CCONT/FNS são compostos pelas chefias, servidores e bolsistas. Os dados referentes à remuneração básica bruta referente as chefias e aos servidores foram obtidos a partir de consulta ao site do portal da transparência, sendo considerado o valor monetário informado no campo "remuneração básica bruta" e dos bolsistas, a partir de consulta com a área responsável pela gestão desses profissionais. Esses dados podem ser considerados como salários percebidos pelos servidores e bolsistas, não sendo considerado os custos que a entidade tem com tais colaboradores.

O material de expediente é composto basicamente de resmas de papel, canetas, tesoura, grampeadores, clipes, entre outros itens. A cada dois meses é solicitado material, sendo as resmas de papel como o item de maior valor nos pedidos. Os valores são os informados pela área responsável. 
Para a apuração do valor referente a serviços de terceiros levaram-se em consideração 6 contratos - de prestação de serviço de brigadistas, vigilância, carregador, estiva, copeira, garçom, entre outros. O Entrevistado 3 (E3), que forneceu os dados, afirmou que é possível haver outros contratos, mas que a consulta retornou apenas os que foram apresentados.

Para a apuração do valor referente a serviços de telefonia levaram-se em consideração 2 contratos. O E3, que forneceu os dados, informou que é possível haver outros contratos, mas que a consulta retornou apenas os que foram apresentados.

Para a apuração do valor referente a serviços de água, foi identificado apenas um contrato que abrange as 6 (seis) unidades do MS em Brasília/DF.

Para a apuração do valor referente a serviços de energia elétrica, foram identificados cinco contratos administrativos, separados por unidade. Neste caso foi considerado o Edifício Sede e o anexo como uma unidade, por ser este o local das atividades.

Em relação ao aluguel e à depreciação, o Entrevistado 3 apresentou o valor global, sem especificações.

Existem outros objetos de custos que não foram viáveis para mensurar, tendo em vista serem áreas extensas que demandam a aplicação do modelo de custos de acordo com as suas atividades e, diante das deficiências de informações disponíveis por parte da instituição, foram desconsiderados.

Essas áreas que foram desconsideradas na apuração abrange os custos com o setor de pessoal, alta gestão, o setor administrativo que processa e realiza o empenho, liquidação de todos os pagamentos, o setor de compras e os programas que são disponibilizados a todos os funcionários do Ministério da Saúde, tais como creches, cursos e programa de bem-estar (ginástica laboral). 


\subsection{3. $3^{\circ}$ Passo: Estimativa da Capacidade Prática do Setor}

No modelo TDABC, conforme descreve Rodrigues, Silva e Araújo (2014), os custos indiretos de cada atividade são alocados aos centros de custos mediante dois parâmetros, o da Taxa do Custo de Capacidade (TCC), que se refere ao Custo da Capacidade Fornecida do Departamento (CCF) dividido pela Capacidade Prática dos Recursos Fornecidos (CPRF), e o da estimativa de tempo para execução de cada atividade.

Com a informação da TCC e do tempo de cada atividade tem-se o valor de cada atividade. Em seguida contabiliza-se o número de atividades que foram realizadas, alocando-se ao objeto de custo. A Figura 5 ilustra a aplicação do modelo TDABC aos processos de TCE.

Figura 5 - Fluxo do Modelo TDABC para o processo de TCE

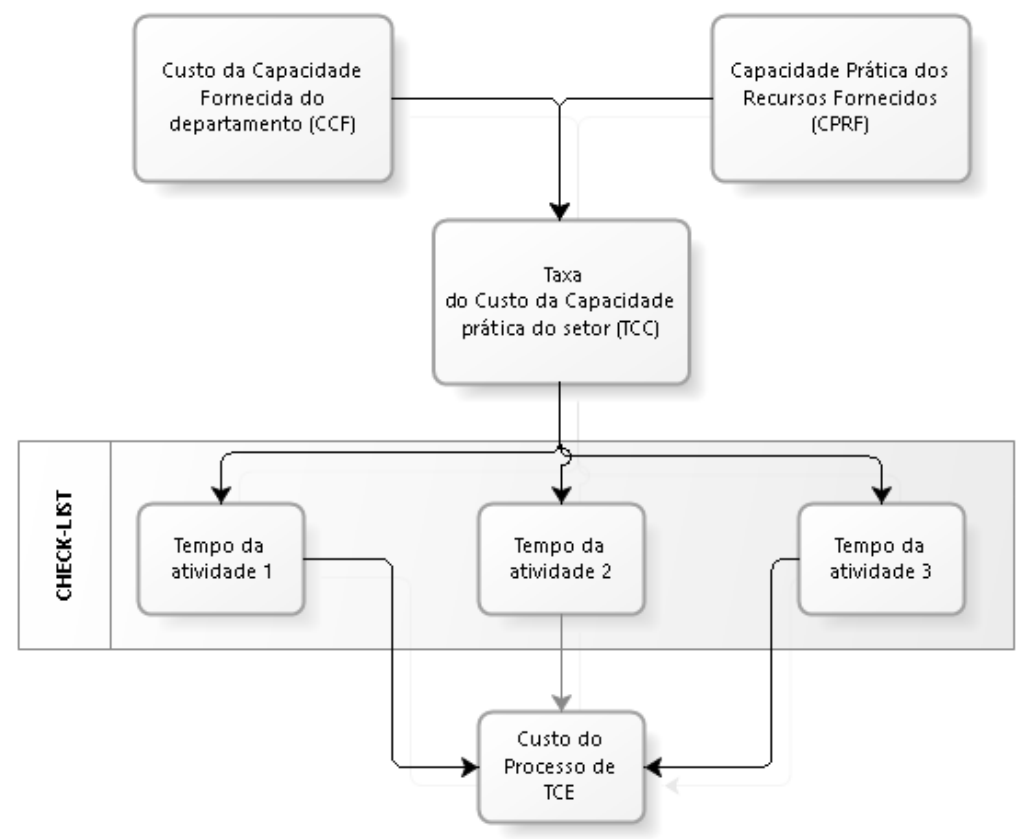

Fonte: Elaborado pela autora, com base em Kaplan e Anderson (2007) 
De acordo com Kaplan e Anderson (2007, p.48):

\begin{abstract}
No caso de um departamento em que o ritmo da produção seja determinado pelo trabalho dos colaboradores, como no caso de um departamento de serviços aos clientes, a capacidade real é medida pela quantidade de minutos ou horas durante as quais os colaboradores estão disponíveis para executar o trabalho (...).
\end{abstract}

Diante do fato de processo de TCE equivaler a fornecimento de serviço, deve-se mensurar a quantidade de minutos disponível para executar o serviço. Um dado para se obter o valor do custo do processo de TCE e, assim, cumprir o $3^{\circ}$ passo exigido pelo modelo TDABC e saber o valor da capacidade prática do setor, conforme demonstrado na Tabela 3.

Tabela 3 - Capacidade prática do setor

\begin{tabular}{c|c}
\hline FATORES & QUANTIDADE \\
\hline Número de colaboradores do setor & 21 \\
Expediente de trabalho em dias por mês & 21 \\
Horas de trabalho por dia & 8 \\
Horas totais disponíveis por mês & 3.528 \\
Minutos por hora & 60 \\
Capacidade teórica do setor (em minutos) & 211.680 \\
Taxa teórica de capacidade prática & $80 \%$ \\
\hline Capacidade pratica do setor (em minutos) & $\mathbf{1 6 9 . 3 4 4}$ \\
\hline
\end{tabular}

Fonte: Elaborado pela autora.

A força de trabalho na CCONT/FNS é composta por 21 colaboradores, entre chefias, servidores e bolsistas, dado este obtido junto ao setor. Nesse trabalho foram considerados 21 dias úteis de expediente de trabalho, conforme adotado por Carraro e Allgaier (2015). A informação quanto à jornada de trabalho, sendo 8 horas de trabalho por dia, também foi obtida junto ao setor.

Com a informação do número de colaboradores, do expediente de trabalho em dias por mês e a jornada de trabalho diária, obteve-se a quantidade de horas totais disponíveis por mês para realizar as atividades, que resultou em 3.528 horas. Para converter em minutos, basta 
multiplicar esse valor por 60, que resultou em 221.680 minutos disponíveis para realizar as atividades mensais. Essa é a capacidade teórica do setor.

Dada a taxa teórica de capacidade prática de $80 \%$, conforme orientado por Kaplan e Anderson (2007), aplicada à capacidade teórica do setor, a capacidade prática do setor ficou em 169.344 minutos. Esse dado vai ser utilizado para atingir o valor da taxa do custo da capacidade do setor, conforme descrito no próximo passo.

\subsection{4. $4^{\circ}$ Passo: Cálculo da Unidade de Tempo}

A necessidade de se dividir o valor total dos recursos pela capacidade prática decorre do objetivo deste trabalho de apuração do custo do processo de TCE na forma de check-list com registros individuais.

Então, para isso, é necessário calcular o valor da taxa do custo da capacidade do setor por minuto, que, conforme Kaplan e Anderson (2007, p. 49) "representa a capacidade real dos recursos que executam o trabalho no departamento". Assim, esse valor se obtém ao se dividir o valor total do custo da capacidade do setor pela capacidade prática do setor, apresentado em minutos, conforme apresentado na Tabela 4.

Tabela 4 - Taxa do custo da capacidade do setor por minuto

\begin{tabular}{l|c}
\hline \multicolumn{1}{c|}{ FATORES } & VALORES \\
\hline Custo da capacidade do setor & $\mathrm{R} \$ 223.772,57$ \\
Capacidade prática do setor (em minutos) & 169344 \\
\hline TAXA DO CUSTO DA CAPACIDADE DO SETOR POR MINUTO & $\mathbf{R} \mathbf{1 , 3 2}$ \\
\hline
\end{tabular}

Fonte: Elaborado pela autora.

A taxa do custo da capacidade se baseia na transação de tempo de cada atividade, conforme afirmam Kaplan e Anderson (2007). Além disso, deve-se considerar que o departamento consome os mesmos recursos para executar todas as atividades, o que viabiliza 
utilizar a taxa da capacidade do setor (KAPLAN e ANDERSON, 2007). Essa taxa é correlacionada ao tempo de cada atividade, conforme descrito no $5^{\circ}$ passo, apresentado na sequência.

\subsection{5. $5^{\circ}$ Passo: Estabelecimento da Unidade de Tempo Despendido em cada Atividade}

Conforme afirmam Kaplan e Anderson (2004b), para se determinar o tempo gasto, os dados podem ser obtidos através de entrevista com o pessoal ou observação direta. Neste caso, foi realizada a entrevista, em que as informações fornecidas pelos Entrevistados 1 e 2, alinhadas ao registro de tempo, subsidiaram a elaboração da Tabela 5.

Tabela 5 - Valor das atividades

\begin{tabular}{|c|c|c|c|c|c|c|}
\hline ATIVIDADES & MINUTO & QNT & $\begin{array}{l}\text { TOTAL DE } \\
\text { MINUTOS }\end{array}$ & $\begin{array}{c}\text { TAXA DO } \\
\text { CUSTO DA } \\
\text { CAPACIDADE }\end{array}$ & \multicolumn{2}{|c|}{$\begin{array}{l}\text { CUSTO } \\
\text { TOTAL }\end{array}$} \\
\hline Assinar o Relatório de TCE & 30 & 3 & 90 & \multirow{12}{*}{$\mathrm{R} \$ 1,32$} & $\mathrm{R} \$$ & 118,93 \\
\hline Realizar triagem e check-list do processo & 120 & 1 & 120 & & $\mathrm{R} \$$ & 158,57 \\
\hline Realizar consulta a sistemas & 120 & 1 & 120 & & $\mathrm{R} \$$ & 158,57 \\
\hline Analisar processo & 360 & 1 & 360 & & $\mathrm{R} \$$ & 475,71 \\
\hline Lançar dados no SISTCE & 360 & 1 & 360 & & $\mathrm{R} \$$ & 475,71 \\
\hline Elaborar Relatório de TCE Preliminar & 120 & 1 & 120 & & $\mathrm{R} \$$ & 158,57 \\
\hline Elaborar despacho de autorização de TCE & 60 & 1 & 60 & & $\mathrm{R} \$$ & 79,28 \\
\hline Inscrever os responsáveis no SIAFI & 30 & 2 & 60 & & $\mathrm{R} \$$ & 79,28 \\
\hline Elaborar Relatório Final de TCE & 120 & 1 & 120 & & $\mathrm{R} \$$ & 158,57 \\
\hline Adotar procedimentos de ajustes no processo & 60 & 1 & 60 & & $\mathrm{R} \$$ & 79,28 \\
\hline Corrigir Relatório de TCE Preliminar & 480 & 1 & 480 & & $\mathrm{R} \$$ & 634,28 \\
\hline Tramitar o Processo & 30 & 1 & 30 & & $\mathrm{R} \$$ & 39,64 \\
\hline VALOR TOTAL DO PROCESSO & 1890 & & 1980 & & $\mathbf{R} \$$ & $.616,39$ \\
\hline
\end{tabular}

Fonte: Elaborado pela autora.

Os entrevistados informaram o tempo médio de execução de cada atividade e a quantidade de vezes em que ela é executada para se concluir o processo de TCE. A partir desse dado, ao multiplicar com a Taxa de Custo da Capacidade do Setor, obtém-se o valor do custo de cada atividade. $\mathrm{O}$ somatório do custo de todas as atividades atende ao $6^{\circ}$ passo. 


\subsection{6. $6^{\circ}$ Passo: Cálculo do Processo de TCE}

A Tabela 5, apresentada no passo anterior, mostra um valor médio de $\mathrm{R} \$ 2.616,39$ para o processo de TCE. Porém, deve-se registrar que existe a natureza particular inerente a cada processo, podendo uns demandar maior tempo de análise do que outros, conforme informado pelo Entrevistado 6. Nesse sentido, alguns processos demandam procedimentos adicionais para instrução.

Porém, os Entrevistados 12 e 16 indicaram que o ideal seria utilizar um valor médio:

(...) mas o ideal seria existir uma estimativa geral para apuração desse valor algo que consiga estimar um tempo ou valor médio, pois só o fator tempo pode ser inviável e parece complicado (...). (E 12).

Então é muito sério você associar a cobrança de um custo de TCE, principalmente com essa variável tempo, e até que se considerasse essa variável tempo, teria que ter o cuidado em afirmar que não é o tempo que o processo levou, é o tempo que um analista dedicou, o que já seria menos ruim. Depois de 5 anos o analista dedicou 40 horas para analisar aquele processo, então são as 40 horas que é o custo daquela TCE, mesmo assim eu acho mais razoável o custo médio, por que de analista para analista, a gente vê pessoas que respondem de forma rápida, outras tendem a fazer que nem necessariamente é o mesmo trabalho, elas atuam de forma diferente, que devem fazer pesquisa e demoram mais tempo, a outra demora menos tempo, mas também o trabalho é mais simples, então entra em uma subjetividade. A taxa média para mim, você ter um valor médio, é menos perigoso. Vai depender do analista que for pegar aquele processo. Então você diz: 'é o método que a gente está utilizando? ', mas você está lidando com seres humanos no final. É a aparente racionalidade das coisas, mas para mim é só aparente, quando você vai ver tem um monte de aspecto subjetivo que não está sendo considerado. (E 15).

Portanto, deve-se ter em mente que existem outras variáveis que devem ser levadas em consideração, tais como o fato que o setor analisa outros tipos de processos e o conhecimento técnico entre os analistas que executam as principais atividades de instauração da TCE.

\subsection{ADAPTAÇÃO AO SIC}


A análise de conteúdo das entrevistas realizadas com um gestor da STN e um analista do MS da CMC gerou 21 subcategorias, que se agrupam em 3 diferentes categorias, em que foi utilizado o sistema QDA Miner Version 4.1.33 para auxiliar nessa atividade. A Tabela 6 informa as categorias, apresentada em ordem de maior impacto, a sub-categoria que se encontra vinculada, apresentada também em grau de maior impacto, a frequência com que cada subcategoria foi citada (podendo ter sido citada mais de uma vez pelo mesmo entrevistado), a quantidade de entrevistados que a mencionaram, com os respectivos percentuais, assim como o fator de impacto, obtido através da multiplicação entre a frequência e número de entrevistados que a citaram.

Tabela 6 - Categorias e subcategorias com maior impacto relacionadas ao SIC

\begin{tabular}{c|l|c|c|c|c|c}
\hline \multirow{2}{*}{ CATEGORIA } & \multirow{2}{*}{ SUBCATEGORIAS } & \multicolumn{2}{|c|}{ FREQUÊNCIA } & \multicolumn{2}{|c|}{ ENTREVISTADOS } & \multirow{2}{*}{ IMPACTO } \\
\cline { 3 - 6 } & & QNT & $\mathbf{\%}$ & QNT & \% & \multirow{2}{*}{ QNT } \\
\hline \multirow{3}{*}{ CARACTERÍSTICAS } & acesso ao sistema & 5 & $11,10 \%$ & 2 & $100,00 \%$ & 10 \\
& integração & 5 & $11,10 \%$ & 2 & $100,00 \%$ & 10 \\
& detalhamento & 4 & $8,90 \%$ & 2 & $100,00 \%$ & 8 \\
\hline
\end{tabular}

Fonte: Elaborado pela autora.

A lista completa com todas as categorias e subcategorias relacionadas com SIC, obtidas por meio das entrevistas, encontra-se no Apêndice D.

As 3 subcategorias com maior impacto, que foram mencionadas mais de quatro vezes e abordadas pelos dois entrevistados são de acesso ao sistema, integração e detalhamento, pertencentes a categoria características.

Na sequência, será abordada cada categoria, iniciando pelas características do SIC, e as subcategorias com maior impacto: acesso ao sistema, integração e detalhamento.

O acesso ao sistema se dá por meio do Tesouro Gerencial (TG), que é um sistema do Governo Federal que fornece relatórios gerenciais aos gestores com base nos dados do SIAFI 
e do SIC e que surgiu em 2015 em substituição ao SIAFI Gerencial. Porém, é necessário ter acesso ao SIAFI com perfil TESCUSTOS. Além disso, a navegação no sistema exige conhecimentos de contabilidade e finanças públicas.

No que concerne ao detalhamento, todos os dados sofrem o processo de extração, transformação e carga, em que há busca, tratamento e disponibilização das informações. Esses dados são disponibilizados com o nível de detalhamento que foi informado e do que é exigido pelo órgão, consoante ao informado na entrevista:

\footnotetext{
Agora se ele quiser um nível maior de detalhamento, refinamento e granularidade, ele define o uso de ferramentas de custos, para o detalhamento de seus custos, nós temos o plano interno, nós temos unidade gestora responsável, mas principalmente o cadastramento de centros de custos no processo de apropriação da despesa, ou em outras situações que envolvem a depreciação, ou uma outra que é em liquidação, passivo anterior, mas em suma, esse refinamento, esse nível de granularidade, ele depende muito da necessidade que o órgão tem, mas isso pode ser expandido, de acordo com o órgão precisar (...) (E4).
}

Portanto, cabe ao órgão estabelecer qual o nível de refinamento dos dados, podendo o detalhamento ser realizado de diversas formas, quando for realizado o registro da execução dos atos administrativos nos sistemas estruturantes do SIC. Então, a STN, como órgão central, fornece as informações básicas por meio do SIC, cabendo ao órgão definir como pretende especificá-la, antes que a informação chegue ao uso do gestor. Após o órgão estabelecer o detalhamento, os dados podem alimentar outros sistemas, tema da sub-categoria integração, relatada pelos entrevistados da seguinte maneira:

O sistema específico do órgão pode gerar um cubo de dados daquilo que você trata e esse sistema utilizar as informações do SIC. (...). É o contrário, esse sistema aí vai buscar informações do SIC. (...). E ele promove o detalhamento lá. O que acontece por exemplo com outros sistemas que os órgãos possuem (E4).

Quanto a esse assunto, observa-se que o SIC gera um cubo de dados que pode ser importado para qualquer sistema, não sendo possível realizar demandas específicas a cada 
órgão, tendo que cada órgão criar meios de gerar as informações da maneira que for mais interessante.

Adentrando na categoria de métodos de custeio, um dos itens refere-se à viabilidade de utilização do método de custeio TDABC para que seja feita a apuração diretamente no SIC. Para isso é necessário que o órgão se organize e faça uma adaptação das rotinas atualmente utilizadas para especificar os centros de custo e os critérios de atribuição dos custos.

Conclui-se com a categoria referente aos problemas encontrados no SIC, que não tiveram subcategorias em comum citadas pelos dois entrevistados, nem fator de impacto significativo, mas que evidenciam os empecilhos que podem ser encontrados ao operacionalizar o sistema, em que foi relatado que os problemas encontrados são referentes as questões do próprio órgão em se organizar para utilizar o SIC, e de adaptação ao tesouro gerencial, que é um sistema recente, e que passou por algumas instabilidades.

\subsection{REEMBOLSO}

Os resultados sobre reembolso são mostrados na Figura 6, sendo observado que a maioria dos entrevistados considera pertinente a cobrança do custo do processo de TCE aos responsáveis, tendo todos opinados que haverá questionamentos adversos referente a essa cobrança. Em relação ao método de apuração escolhido, a metade dos entrevistados considerou válida a apuração e a forma de cobrança baseada em tempo e atividades. A outra parte dos entrevistados cita várias ressalvas em relação à proposta de apuração e informa que existe um universo de variáveis, além de atividade e tempo. Para alguns destes, deveria ser aplicada a metodologia já utilizada pelo Judiciário, com uma estimativa geral de um valor médio, razoável e conservador; outros destes sugeriram considerar também o custo de oportunidade entre os 
critérios de apuração. Existem ainda aqueles que consideram esse tipo de cobrança utópica e de difícil apuração.

Figura 6 - Fluxograma das categorias de reembolso

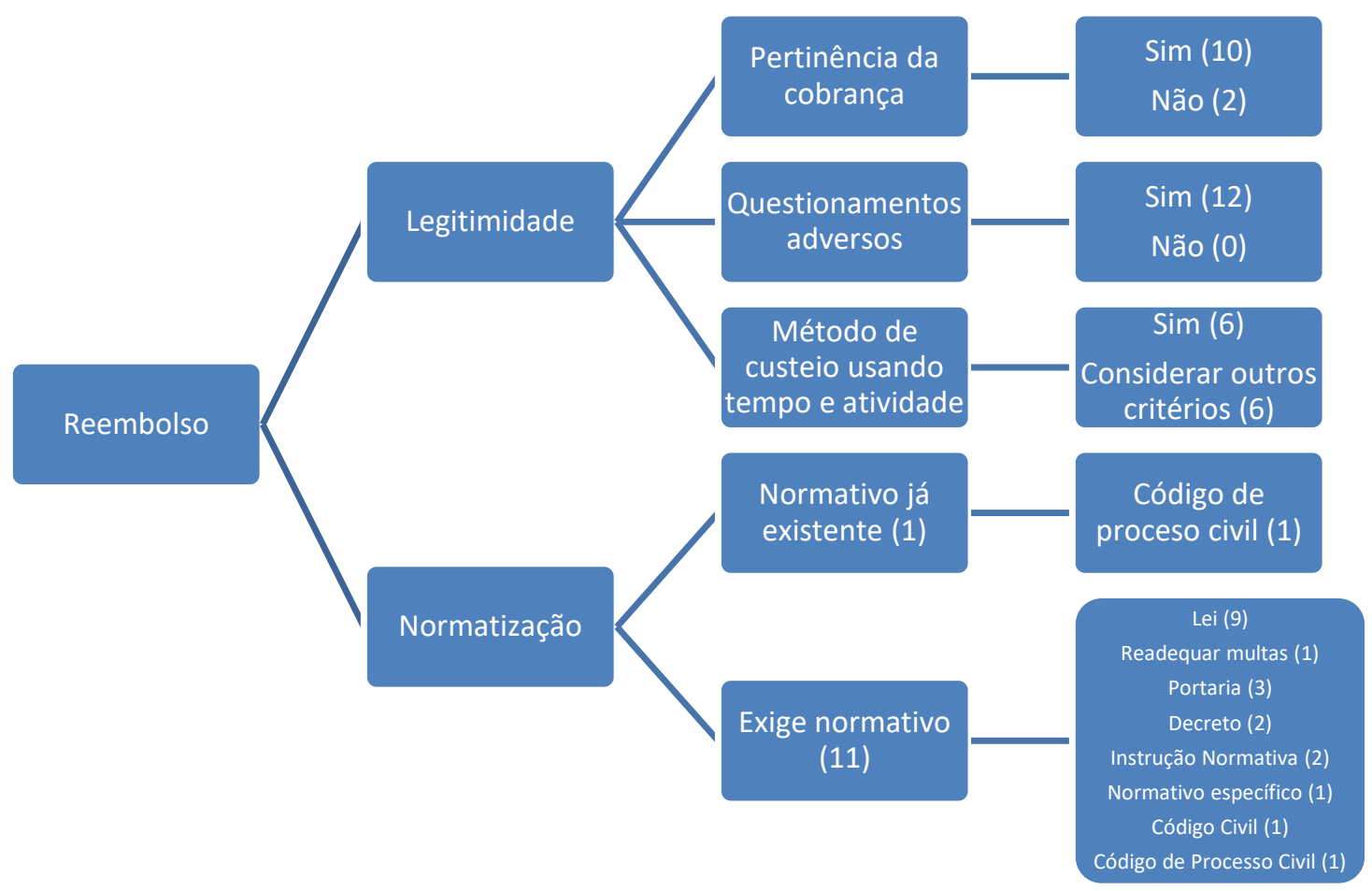

Fonte: Elaborado pela autora.

O que se encontrou em comum, na maioria dos resultados das entrevistas, foi a demanda por instrumento normativo para viabilizar a cobrança do processo de TCE. Assim, a pertinência da cobrança desses custos deve ser inicialmente estabelecida por meio de uma lei, autorizando a cobrança e permitindo que cada órgão defina os critérios e metodologias, como sugerido por um dos entrevistados "A lei seria um autorizativo para o início da cobrança (...) ou uma orientação geral que cada órgão esteja autorizado a utilizar a sua métrica” (E16).

Em relação à análise de conteúdo das entrevistas, esta gerou 49 subcategorias, que se agrupam em 5 diferentes categorias. A Tabela 7 informa as categorias, apresentada em ordem de maior impacto, a subcategoria que se encontra vinculada, apresentada também em grau de 
maior impacto, a frequência com que cada subcategoria foi citada (podendo ter sido citada mais de uma vez pelo mesmo entrevistado), a quantidade de entrevistados que a mencionaram, com os respectivos percentuais, assim como o fator de impacto, obtido através da multiplicação entre a frequência e número de entrevistados que a citaram.

Tabela 7 - Categorias e subcategorias com maior impacto referente ao reembolso

\begin{tabular}{|c|c|c|c|c|c|c|}
\hline \multirow{2}{*}{ CATEGORIA } & \multirow{2}{*}{ SUBCATEGORIA } & \multicolumn{2}{|c|}{ FREQUÊNCIA } & \multicolumn{2}{|c|}{ ENTREVISTADOS } & \multirow{2}{*}{ IMPACTO } \\
\hline & & QNT & $\%$ & QNT & $\%$ & \\
\hline $\begin{array}{c}\text { APURAÇÃO DO } \\
\text { CUSTO }\end{array}$ & $\begin{array}{l}\text { aspectos metodológicos da } \\
\text { apuração }\end{array}$ & 20 & $9,40 \%$ & 10 & $83,30 \%$ & 200 \\
\hline \multirow{2}{*}{$\begin{array}{l}\text { COBRANÇA DO } \\
\text { CUSTO }\end{array}$} & pertinência da cobrança & 18 & $8,50 \%$ & 11 & $91,70 \%$ & 198 \\
\hline & normativo necessário & 15 & $7,10 \%$ & 11 & $91,70 \%$ & 165 \\
\hline \multirow{2}{*}{$\begin{array}{c}\text { QUESTIONAMENTOS } \\
\text { ADVERSOS }\end{array}$} & existência de & 15 & $7,10 \%$ & 11 & $91,70 \%$ & 165 \\
\hline & $\begin{array}{l}\text { questionamentos adversos } \\
\text { multa }\end{array}$ & 13 & $6,10 \%$ & 4 & $33,30 \%$ & 52 \\
\hline $\begin{array}{c}\text { INSTAURAÇÃO DA } \\
\text { TCE }\end{array}$ & $\begin{array}{l}\text { adoção de medidas } \\
\text { administrativas }\end{array}$ & 14 & $6,60 \%$ & 5 & $41,70 \%$ & 70 \\
\hline
\end{tabular}

Fonte: Elaborado pela autora.

A lista completa com todas as categorias e subcategorias referente ao reembolso, obtidas por meio das entrevistas, encontra-se no Apêndice E.

As 6 subcategorias com maior impacto, e que foram citadas mais de 10 vezes, e com fator de impacto superior a 50, são as referentes aos aspectos metodológicos da apuração, à pertinência da cobrança, ao normativo necessário, à existência de questionamentos adversos, à adoção de medidas administrativas e à multa.

Na sequência, apresentam-se as cinco categorias analisadas. A primeira refere-se à apuração de custo do processo de TCE, que dentre as 12 subcategorias identificadas, apenas uma se destacou pelo número de menções e fator de impacto, que é a relacionada aos aspectos metodológicos da apuração do custo do processo de TCE, em que o Entrevistado 6 considera o “(...) tempo e os recursos que se consumiram para realizar a instauração", enquanto que o 
Entrevistado 11 afirmou que “(...) essa metodologia deve ser validada considerando outras metodologias já utilizadas, como as usadas no Judiciário, para serem usadas como paradigma".

Para o Entrevistado 17 o que importa, em relação à metodologia, é que se adote um critério, conforme anunciado, quando questionado sobre o método de apuração TDABC: “concordo, não conheço em essência o método, mas é um critério. Se vai adotar um critério, vai adotar tempo naquela tarefa. Você tem às vezes como se mensurar esse tempo, o valor em si vai ser mensurado nesse critério".

Os entrevistados fizeram ressalvas quanto ao que pode e não pode fazer parte desse custo, e afirmam que deve fazer parte do custo o tempo de instauração da TCE, envolvendo todas as fases de instauração, enquanto não deve ser levado em consideração o tempo de espera do processo para ser analisado.

A próxima categoria a ser debatida é a que aborda a questão da cobrança do custo do processo de TCE, visando ao reembolso para Administração Pública, que tem como as principais subcategorias a pertinência da cobrança e o normativo necessário, sendo esta última variável já abordada, quando foi constatado que a maioria dos entrevistados consideraram necessário estabelecer uma Lei para o início da cobrança, conforme afirma o Entrevistado 17 “existe um princípio básico da Constituição que diz que ninguém é obrigado a fazer ou deixar de fazer senão em virtude de Lei. Então eu acho que deveria ter alguma Lei estabelecendo isso".

Quanto à pertinência da cobrança do custo do processo de TCE, existem posicionamentos opostos a essa cobrança, embora a maioria dos entrevistados fosse a favor com fundamento nos seguintes argumentos:

Não existe ainda essa prática, mas seria interessante né! Já que ele cometeu, mas assim o erro de não ter feito alguma falha, seria ideal que pudesse realmente cobrar isso dele. (...) é uma prática que está se espalhando pelo mundo. A gente ver, por exemplo, acidentes com moto e essas coisas estão cobrando inserção em hospitais, cobrando 
dos planos de saúde pessoas que estão ficando incapacitados, o INSS está começando a cobrar isso nas pessoas que causaram a incapacidade. É interessante o questionamento, vai existir, eu vejo isso acontecendo há bastante tempo (E10).

(...) se puder ótimo, por que como no direito civil quem causar dano vai ter que reparar e ressarcir, e em política pública o custo é muito grande. A realização de políticas públicas fica muito prejudicada com essas questões, pois para transferir recurso a um município, outros 5 mil deixaram de receber, e tem envolvimento político, técnico, financeiro, tem uma série de coisas envolvidas (E17).

Os principais argumentos favoráveis envolvem a questão de ser uma tendência em realizar a cobrança de atos administrativos para fins de reembolso para Administração Pública, quanto à racionalidade econômica administrativa. Ademais, há o fato de que, ao se transferir recursos a um determinado município, outros deixaram de ser contemplados. No momento em que o recurso não foi aplicado ao fim a que se destinava, prejudica a execução das políticas públicas em ambos os municípios.

Em contraponto, dois dos entrevistados têm o entendimento que não se deve proceder a cobrança do custo do processo de TCE, pois partem do pressuposto que se deve fortalecer as multas, até mesmo incluindo o valor do custo do processo, tendo em vista que a quantidade de encargos que existem já é o suficiente. Além disso, não seria uma pauta a ser discutida nesse momento, tendo outros questionamentos que deveriam ser debatidos, antes de se pensar em aumentar os encargos aos responsáveis apontados no processo de TCE.

Adentrando para a categoria dos questionamentos adversos, e conforme já citado, todos os entrevistados consideraram que haverá controvérsias em relação a essa cobrança, sendo os principais questionamentos referentes ao fato de que a apuração de responsabilidade é uma atribuição da Administração Pública, a falta de previsão legal para a cobrança, além da eventual incidência de multa, juros e atualização monetária, já que esses valores são cobrados ao ser instaurada a TCE. 
Fica patente a preocupação dos entrevistados diante do fato de que a Administração Pública já é custeada por impostos e a iniciativa em começar um processo de cobrança e instauração da TCE é da Administração Pública. Contudo, há que se considerar também o fato de que é a recusa do polo devedor em solver a obrigação perante o erário que determina a instauração da TCE e que a cobrança do custo desta não incidirá, se a responsabilidade pela obrigação principal não subsistir ao final do contraditório e da ampla defesa.

A subcategoria multa reflete a existência de outras cobranças, e que para os entrevistados revê-la seja mais viável e eficiente do que estabelecer mais um encargo de cobrança e que muitas vezes o responsável deixa de quitar o débito diante do excesso de cobranças acessórias. Vale lembrar, contudo, dos argumentos já expedidos, de que o manuseio de recursos públicos é um dever, não um direito privado disponível, e de que os fundamentos e multas, juros remuneratórios ou punitivos e atualização monetária enfatizam a obrigação principal e não abrangem a recomposição do custo da TCE, instaurada pela recusa do devedor em compor a obrigação sem esse processo administrativo adicional para a recomposição do patrimônio público.

A próxima categoria a ser debatida é a referente à instauração de TCE, em que a variável com maior enfoque foi a referente à adoção de medidas administrativas. Foi unânime entre os entrevistados, que abordaram esse tema, que a TCE só pode ser iniciada após a adoção de medidas administrativas, conforme afirmam Quintão e Carneiro (2015, p. 479) que a TCE “é cabível depois de esgotadas as medidas administrativas internas com vistas à regularização das contas ou de ressarcimento do dano". 
Além disso, há um ponto, que foi citado pelos Entrevistados 6 e 7, referente à ampla defesa e ao contraditório, que é uma etapa das medidas administrativas, e quanto ao objetivo de aplicação dos recursos no que foi destinado:

\begin{abstract}
Mas uma outra coisa que se faz necessário para que isso aconteça é você iniciar o processo em uma condição, onde de fato você possa garantir ampla defesa e contraditório de todas as condições, quer seja no convênio ou na auditoria, para que nós possamos realmente separar, aquilo que é erro ou se houve de fato o prejuízo (E6).

E por se tratar de tomada de contas especial, que, como a gente falou aqui, é um processo de exceção, entendo também que se o processo administrativo for bem conduzido, ele vai inibir o processo de tomada de contas especial. Porque o que se quer quando se libera recurso para uma determinada finalidade, que essa finalidade seja atendida e cumprida, e todos os esforços pedagógicos e orientadores, que a TCE tem que ser evitada, para que os recursos sejam bem aplicados, evitando, com isso, a necessidade de se buscar um recurso, aplicando aí, o Normativo existente de atualização de valores e etc., para que o dinheiro volte aos cofres públicos, porque, na realidade, o que se quer é que o dinheiro seja aplicado em serviços de qualidade para a sociedade (E7).
\end{abstract}

Desse modo, observa-se que a fase preliminar, de esgotamento de outras alternativas de composição do dano, é importante do processo de TCE, o que demonstra a excepcionalidade do processo. Caso seja obtida essa composição, evita-se o prosseguimento da cobrança, com a instauração da TCE, e obtém-se a correta aplicação dos recursos, conforme foram destinados.

A quinta e última categoria coletada na pesquisa é referente a ação de cobrança, que não apresentou fator de impacto significativo, mas que apresentou a hipótese relacionada a culpa para administração pública caso inicie um processo de uma cobrança sem a certeza do débito ou da culpa do responsável, podendo anular todo o processo de TCE e gerar perdas morais para o responsável indicado.

Portanto, diante de todo o exposto, pode-se inferir que existe a necessidade de aplicação de formas rigorosas de penalização ao responsável que, ao não aplicar o recurso no que foi destinado, prejudica a população e o município, tendo como consequência a perda de direitos políticos, já que reflete uma ação de improbidade, e até mesmo o bloqueio de bens durante a 
fase de julgamento no TCU, para que possa ser efetivado o ressarcimento ao erário. Contudo, essa linha de raciocínio desconsidera a demanda constitucional de ressarcimento ao erário e o atendimento do preceito jurídico básico do direito das gentes de neminem laedere (não lesar ninguém, em tradução livre). Isso porque a multa é uma sanção, isto é, tem caráter retributivo e punitivo, não de recomposição do patrimônio lesado, que é o princípio em destaque na apuração e ressarcimento dos custos em apreço. 


\section{CONCLUSÃO}

O objetivo geral desse trabalho foi Identificar meios de obtenção do reembolso para a Administração Pública do custo do processo da TCE. Para isso, o referencial teórico iniciou abordando sobre gastos e custos públicos para fundamentar que essa questão é relevante no Brasil e no mundo. Na sequência, foram apresentados os métodos de custeio mais conhecidos, evidenciando as vantagens e desvantagens de cada um, sendo especificado o método de custeio TDABC, sendo este método escolhido para ser utilizado para apurar o custo do processo de TCE no FNS.

A ênfase nos conceitos que envolvem a TCE também fez parte do referencial teórico assim como as características do FNS, ambiente de aplicação do estudo de caso. A revisão do reembolso abordou como ele acontece em várias partes do mundo e constatou que a prática de apuração do custo dos procedimentos para posterior reembolso é recorrente em ambientes hospitalares e demais estabelecimentos de saúde. O reembolso é o que motiva a realização da apuração do custo do processo de TCE e o que enseja essa cobrança, tendo como finalidade inibir as ações de mal-uso dos recursos públicos. A revisão do SIC, que foi o instrumento que se intenciona que apure o custo do processo de TCE, embasou a expectativa do uso desse sistema para posterior reembolso do custo das TCEs.

A pesquisa foi conduzida por quatro objetivos específicos, que em sua essência são distintos, mas que se complementam para cumprir o objetivo geral desse trabalho. O primeiro foi referente ao mapeamento do processo de TCE. No órgão estudado existem dois mapeamentos que foram elaborados, um com a finalidade de projetar um novo sistema, disponível no Anexo A, e o outro para orientar as ações gerais que ocorrem no setor. Ambos os mapeamentos abrangem todas as atividades que o setor executa, extrapolando os limites da TCE 
e, por isso, não atendem à finalidade dessa pesquisa. Desse modo, foi elaborado um mapeamento específico para apuração do custo do processo de TCE e que atende a aplicação do método TDABC para apurar esse custo.

Portanto, a partir dos dados obtidos nas entrevistas e da consulta aos documentos institucionais, foi possível realizar o mapeamento do processo de TCE no FNS e confirmar a primeira expectativa de resultado, que afirma que o mapeamento já existente no FNS não atende a aplicação do método de custeio TDABC.

O segundo objetivo específico foi referente à apuração do custo do processo de TCE, utilizando o modelo TDABC. Foi aplicado o método, a partir dos dados obtidos junto aos entrevistados e, com isso, foi possível alcançar o valor de $\mathrm{R} \$ 1,32$ por minuto de tempo, como taxa do custo da capacidade, que deve ser aplicado em cada atividade desenvolvida na CCONT/FNS.

Considerando que os recursos são os mesmos para realizar as atividades, já que a equipe é a mesma, não há alteração do valor do minuto para o desenvolvimento das atividades de instauração da Tomada de Contas Especial e, portanto, o valor do processo de TCE, que se alcançou a partir de uma estimativa média, é de $\mathrm{R} \$ 2.616,39$. Se considerar o quantitativo de TCEs remetidas ao TCU em $2016^{3}$, que totalizou 105 , o valor resultaria em R $\$ 274.720,79$, e o acumulado de 2002 a 2015, totaliza em R\$ 14.039.540,74, referente às 5.366 TCEs instauradas.

A intenção é que, no momento da instauração da TCE, já se saiba o valor do custo dispendido para a instauração, para a imputação imediata da responsabilidade ao gestor causador do dano, em acréscimo aos demais valores.

\footnotetext{
${ }^{3}$ Atualizado em 31/03/2016
} 
A expectativa de resultado a ser debatida nesse objetivo específico é se o TDABC dá conta da apuração do custo do processo de TCE, o que pode ser confirmado, tendo em vista que foi possível obter o valor do custo do processo de TCE no estudo de caso do FNS. Apesar das limitações do método, evidenciadas no referencial teórico dessa pesquisa e que, embora os pesquisadores devam trabalhar em direção à medida ideal do valor, esse instrumento de apuração pode ser aperfeiçoado ao longo do tempo de uso.

O terceiro objetivo específico buscou sugerir a adaptação ao SIC para apuração do custo dos processos de TCE e, após a análise dos dados coletados, pode-se chegar à conclusão que ainda não há meios para se adaptar o SIC para apuração dos processos de TCE, incentivando futuros estudos a aprofundarem o tema.

Foi identificado que, apesar de estar prevista na concepção do sistema, a apuração do valor do custo do serviço público não é uma prática utilizada, tendo em conta que só há dados referentes a valores globais relacionados a políticas ou unidades orçamentárias préestabelecidas pela Lei Orçamentária Anual, não estabelecendo valores e preços específicos de serviços. Para isso, seria necessário rever os procedimentos de registros orçamentários e financeiros para determinar as informações do que é necessário para obter o valor de um serviço em específico, conforme infere-se das entrevistas.

Ao acessar o sistema, não foi possível identificar os dados que pudessem ser utilizados para o cálculo do processo de TCE. Em entrevista com o gestor da STN, este informou acerca da impossibilidade de adaptação do SIC a outros sistemas, sendo necessário que estes se adaptem ao SIC. Além disso, o método de custeio utilizado pelo SIC é o método direto, enquanto que a apuração por esse estudo foi pelo TDABC. 
Existe uma possibilidade futura, caso os dados sejam previamente tratados por meio dos respectivos lançamentos via SIAPE, SIAFI, SIORG e SIOP, antes de serem migrados para o SIC, que o SISTCE importe esses dados e viabilize a apuração. Com as informações mais refinadas e disponibilizadas ao SISTCE, será possível realizar a apuração do processo de TCE por meio do SIC. Enquanto esse ajuste não ocorra, não é possível realizar a apuração por esse sistema.

Sobre esse assunto, observa-se e alude-se à necessidade de superação no contexto da contabilidade pública da falta de integração entre os sistemas estruturantes e a falta de padronização nas estruturas organizacionais do Governo Federal, garantindo que futuros pesquisadores possam se debruçar sobre a temática.

Existe ainda a limitação quanto aos dados referentes aos recursos humanos, pois nem todos que atuam na CCONT/FNS são servidores e, portanto, a remuneração pelos serviços prestados pelos bolsistas não consta no SIAPE, dificultando a forma de obtenção desses dados no SIC, e fazer com que ela possa ser detalhada e agregada para a apuração do processo de TCE. Para essa pesquisa foi possível obter os dados junto ao setor que gerencia esses profissionais, porém esses dados não estão no SIC.

Assim, embora os gastos relacionados à TCE constem no orçamento, falta discriminálos como custos e apropriá-los a quem lhe deu causa. Portanto, ao se observar a expectativa de resultado elaborada para cumprimento desse objetivo, que retrata se SIC é um sistema de custo adequado para apuração do custo do processo de TCE, pode-se negá-la nesse momento, já que ele não atende a possibilidade de apuração do custo do processo de TCE, além de ter se mostrado inviável ao alcance desse objetivo específico. 
Em relação ao quarto e último objetivo específico, que buscou propor meios que contribuam para a Administração Pública obter o reembolso do valor gasto nos processos de TCE, tem-se como sugestão a elaboração de uma Lei ordinária para o início da cobrança do custo do processo de TCE, considerando que a maioria dos participantes da pesquisa entende que é necessária uma lei para estabelecer o início da cobrança e, portanto, recomendam que o próprio Ministério da Saúde realize essa proposta à Casa Civil, para que intermedeie junto ao Poder Legislativo.

Outra alternativa indicada por esse estudo é apresentar diretamente essa proposta à Câmara dos Deputados. Para apresentar um projeto de lei de iniciativa popular, a Constituição Federal exige subscrição por, no mínimo, um por cento do eleitorado nacional, distribuído pelo menos por cinco Estados, com não menos de três décimos por cento dos eleitores de cada um deles. Alternativamente, a Comissão de Legislação Participativa (CLP) dessa mesma Câmara recebe propostas entregues pelas entidades civis organizadas ou individualmente, pelo cidadão. Assim, é possível apresentar contribuições por intermédio de sugestões, que são incorporadas ao "banco de ideias" da Comissão.

Portanto, em um tema que envolve a sociedade civil e em que a maioria dos participantes desta pesquisa considera pertinente a instituição de uma Lei para o início da cobrança, é mister seguir o rito legislativo, tendo este trabalho realizado as sugestões de Projeto de Lei e Expediente de Encaminhamento de Sugestão, constante no Apêndice F, nos moldes dos modelos disponíveis no sítio eletrônico da Câmara dos Deputados.

A expectativa de resultado estabelecida para esse objetivo específico, de que faltam normas incentivadoras da apuração e do reembolso do custo do processo de TCE, confirma-se parcialmente, já que alguns entrevistados apontaram a existência do Código Civil e do Código 
de Processo Civil como fundamentos para a cobrança do custo do processo de TCE para fins de reembolso. Ainda assim, seria necessária uma regulamentação específica, pelo que se justifica a proposta de uma lei ordinária.

Conforme alguns dos informantes, a cobrança do custo desse processo tem como analogia a imposição de pagamento de custas judiciais, que podem limitar o acesso à justiça. Contudo, por disposição constitucional, qualquer agente está sujeito à ação regressiva, quando houver dano ao erário por culpa ou dolo.

A imposição de pagamento de custas de processos de Tomada de Contas Especial poderia diminuir os casos de falta de prestação de contas, já que seria mais uma penalidade, corroborando com a opinião de gestores e analistas que consideram pertinente a cobrança do custo desse processo. Sob essa ótica, o estabelecimento de cobrança do custo do processo de TCE pode inibir o início desse tipo de processo, dada a ressalva de que no caso de ausência de culpa ou dolo do responsável pelo débito principal, não haveria a obrigatoriedade pelo ressarcimento desse montante acessório.

Vale ressaltar que para a cobrança dos processos, segundo os gestores, seria necessário tornar o processo de TCE mais eficiente e evitar instaurações desnecessárias e que não tenham todos os pressupostos. Assim sendo, atingir o quarto objetivo específico envolveu os outros três, quanto ao cumprimento do mapeamento das atividades, da apuração do valor do custo do processo por um método de custeio defensável em juízo e em observar meios sistêmicos de aferição do valor. Esses são requisitos preliminares para obter maneiras legais de realizar a cobrança, com a possibilidade de reembolso para a Administração Pública.

Dessa forma, quanto à segunda parte do problema de pesquisa, que buscou saber como obter o reembolso do custo do processo de TCE, sendo este calculado por meio do SIC, a 
pesquisa mostrou que a resposta para esta pergunta é que o SIC ainda não oferece condições de realizar a apuração do custo do processo de TCE. Porém, utilizando-se de outros sistemas desenvolvidos pelo próprio órgão, que busquem informações no SIC, há a possibilidade de apuração. Para a obtenção do reembolso, é necessário que exista uma previsão legal para essa cobrança, sendo recomendado uma Lei ordinária.

Portanto, após as considerações acima, foi possível analisar a aplicabilidade do modelo TDABC, no FNS, que se apresentou um método fácil e adequado, e propor as medidas de reembolso e, consequentemente, responder o problema de pesquisa e cumprir os objetivos específicos e, consequentemente, o objetivo geral.

No que concerne às limitações dessa pesquisa, pode-se citar que a metodologia de apuração do custo do processo de TCE, pelo método de apuração TDABC, foi aplicado apenas em um estudo de caso do FNS, devendo ser aplicado aos outros órgãos que fazem parte do processo de TCE, para que se tenha o valor de todo o ciclo do processo. Se mostra necessário ainda, a apuração em outros órgãos instauradores, para que se tenha medidas de comparação com múltiplos casos.

Outrossim, não foram considerados os custos indiretos não vinculados às atividades de TCE, como por exemplo os recursos humanos, financeiro, alta gestão, entre outros, obtendo um valor que pode ser considerado valor médio mínimo, sendo o custo base do processo da TCE na CCONT/FNS, e que está subestimado. Há ainda a limitação que envolve a aplicação do roteiro de entrevista $\mathrm{n}^{\circ} 02$ a apenas uma pessoa.

Quanto às recomendações, sugere-se que o MS adote medidas para viabilizar, junto à Casa Civil, a proposta de lei ordinária constante no Apêndice F, realize uma avaliação para o reconhecimento da apuração do custo do processo de TCE pelo método proposto, a partir de 
uma comissão instituída pelo Poder Público, antes da efetiva implementação e, ainda, após a realização da validação, e realize a adaptação do SISTCE para que possibilite a apuração sistemática do custo dos processos de TCE na CCONT/FNS.

Propõe-se que se realize a apuração desse custo em outros órgãos envolvidos no processo, assim como outros órgãos instauradores, para se obter medidas comparativas, e que, conforme foi apontado nas entrevistas, seja possível que os recursos provenientes do reembolso do processo possam auxiliar as áreas instauradoras a se estruturarem, ou que, seja destinada à educação e ao aperfeiçoamento continuados dos servidores. Algo semelhante já ocorre no Tribunal de Contas do Estado do Paraná, que reverte parte das multas recebidas em programas de educação permanente aos servidores daquele Tribunal.

Para se obter o custo total, em sua plenitude, deve-se aplicar o método TDABC a todos os setores do Ministério da Saúde, pois estão indiretamente ligadas ao processo de TCE, como recursos humanos, financeiro, alta gestão, entre outros, a serem avaliados em tempo oportuno.

Recomenda-se também que a administração pública não analise processos com valores inferiores ao apurado, focando na qualidade do custo público. Quanto à atualização, que seja realizada anualmente, reaplicando o método, sem utilizar índices pré-estabelecidos. Observase ainda a necessidade de um maior refinamento e detalhamento dos dados, e que a coleta de dados, por meio das entrevistas, tenha a participação de mais de uma pessoa de cada área.

Cabe ampliar as pesquisas, quanto a gastos e custos públicos da administração pública, assim como acerca das medidas reembolso e ressarcimento, tendo em vista que esta pesquisa não esgotou as discussões que esses temas oferecem.

Cumpre lembrar que o TCU pode dispor sobre os elementos integrantes das TCEs em seu Regimento Interno, conforme dispõe o art. $9^{\circ}$ da sua já mencionada Lei Orgânica. Assim, 
embora não tenha sido explicitamente mencionado pelos informantes, caberia também investigações adicionais sobre possibilidade de que aquela Corte de Contas determine a explicitação do custo das TCEs na elaboração dos cálculos do dano indenizável. 


\section{REFERÊNCIAS}

ABBAS, Katia; GONÇALVES, Marguit Neumann; LEONCINE, Maury. Os métodos de custeio: vantagens, desvantagens e sua aplicabilidade nos diversos tipos de organizações apresentadas pela literatura. Contexto, v. 12, n. 22, p. 145-159, 2012.

AFONSO, Antônio; SCHUKNECHT, Ludger; TANZI, Vito. Income distribution determinants and public spending efficiency. The Journal of Economic Inequality, v. 8, n. 3, p. 367-89, 2010.

ALONSO, Marcos. Custos no serviço público. Revista do Serviço Público, v. 50, n. 1, p. 37 63, 1999.

ASHRAF, Junaid; UDDIN, Shahzad. New public management, cost savings and regressive effects: A case from a less developed country. Critical Perspectives on Accounting, 2015.

AZIZ, Mohamad Azizal Abd; RAHMAN, Hilmi Ab; ALAM, Md Mahmudul; SAID, Jamaliah Enhancement of the Accountability of Public Sectors through Integrity System, Internal Control System and Leadership Practices: A Review Study. Procedia Economics and Finance, v. 28, p. 163-9, 2015.

BARDIN, Lawrence. Análise de conteúdo. 3. reimp. Lisboa: Edições, v. 70, 2011.

BELLANGER, Martine; TARDIF, Laurent. Accounting and reimbursement schemes for inpatient care in France. Health Care Management Science, v. 9, n. 3, p. 295-305, 2006.

BIAZEBETE, Célia Martelli; BORINELLI, Márcio Luiz; CAMACHO, Reinaldo Rodrigues. Análise da aplicação do custeio alvo e do custeio pleno em indústria de confecções: um estudo de caso. Revista de Contabilidade e Organizações, v. 3, n. 5, p. 44-61, 2009.

BOINA, Terence Machado; AVELAR, Ewerton Alex; SOUZA, Antônio Artur; RIBEIRO, Lívia Maria de Pádua. Analise bibliométrica de trabalhos acadêmicos sobre o time-driven activity-based costing publicados em periódicos entre os anos de 2004 e 2013. Revista Universo Contábil, v. 11, n. 4, p. 166, 2015.

BOSANQUET, Nick. From welfare state to entitlement programmes. Futures, v. 44, n. 7, p. 666-70, 2012.

BRASIL. Lei n ${ }^{\circ} 4.320$, de 17 de março de 1964. Estatui Normas Gerais de Direito Financeiro para elaboração e contrôle dos orçamentos e balanços da União, dos Estados, dos Municípios e do Distrito Federal. Diário Oficial [da] República Federativa do Brasil, Brasília, DF, 23 mar. 1964. Disponível em: <https://www.planalto.gov.br/ccivil_03/leis/L4320.htm>. Acesso em: 03 nov. 2016.

Decreto-Lei $n^{\circ}$ 200, de 25 de fevereiro de 1967. Dispõe sôbre a organização da Administração Federal, estabelece diretrizes para a Reforma Administrativa e dá outras providências. Diário Oficial [da] República Federativa do Brasil, Brasília, DF, 27 fev. 
1967. Disponível em: < https://www.planalto.gov.br/ccivil_03/Decreto-Lei/Del0200.htm>. Acesso em: 03 nov. 2016.

Decreto $n^{\circ}$ 64.867, de 24 de julho de 1969. Institui o Fundo Nacional de Saúde (FNS), vinculado ao Ministério da Saúde e dá outras providências. Diário Oficial [da] República Federativa do Brasil, Brasília, DF, 25 jul. 1969. Disponível em: $<$ https://www.planalto.gov.br/ccivil_03/decreto/Antigos/D64867.htm>. Acesso em: 03 nov. 2016.

Constituição da República Federativa do Brasil. 1988. Disponível em: <http://www.planalto.gov.br/ccivil_03/constituicao/constituicao.htm>. Acesso em: 9 jul. 2015.

Lei $n^{\circ} 8.080$, de 19 de setembro de 1990. Dispõe sobre as condições para a promoção, proteção e recuperação da saúde, a organização e o funcionamento dos serviços correspondentes e dá outras providências. Diário Oficial [da] República Federativa do Brasil, Brasília, DF, 20 set.1990a. Disponível em: <http://www.planalto.gov.br/ccivil_03/leis/L8080.htm>. Acesso em: 04 nov. 2016

. Lei n ${ }^{\circ} 8.142$, de 28 de dezembro de 1990. Dispõe sobre a participação da comunidade na gestão do Sistema Único de Saúde (SUS) e sobre as transferências intergovernamentais de recursos financeiros na área da saúde e dá outras providências. Diário Oficial [da] República Federativa do Brasil, Brasília, DF, 31 dez.1990b. Disponível em: <http://www.planalto.gov.br/ccivil_03/LEIS/L8142.htm>. Acesso em: 03 nov. 2016.

Lei $n^{\circ}$ 8.443, de 16 de julho de 1992. Dispõe sobre a Lei Orgânica do Tribunal de Contas da União e dá outras providências. Diário Oficial [da] República Federativa do Brasil, Brasília, DF, 17 jul.1992. Disponível em: <http://www.planalto.gov.br/ccivil_03/Leis/L8443.htm>. Acesso em: 03 nov. 2016.

Lei $\mathrm{n}^{\circ}$ 9.289, de 4 de julho de 1996. Dispõe sobre as custas devidas à União, na Justiça Federal de primeiro e segundo graus e dá outras providências. Diário Oficial [da] República Federativa do Brasil, Brasília, DF, 5 jul.1996. Disponível em: <http://www.planalto.gov.br/ccivil_03/leis/L9289.htm>. Acesso em: 03 nov. 2016.

. Decreto $\mathrm{n}^{\circ}$ 6.976, de 7 de outubro de 2009. Dispõe sobre o Sistema de Contabilidade Federal e dá outras providências. Diário Oficial [da] República Federativa do Brasil, Brasília, DF, 8 out. 2009. Disponível em: <http://www.planalto.gov.br/ccivil_03/_Ato20072010/2009/Decreto/D6976.htm>. Acesso em: 05 nov. 2016.

Decreto $\mathrm{n}^{\circ} 8.065$, de 7 de agosto de 2013. Aprova a Estrutura Regimental e o Quadro Demonstrativo dos Cargos em Comissão e das Funções Gratificadas do Ministério da Saúde e remaneja cargos em comissão. Diário Oficial [da] República Federativa do Brasil, Brasília, DF, 8 ago. 2013. Disponível em: <http://www.planalto.gov.br/CCIVIL_03/_Ato2011-2014/2013/Decreto/D8065.htm>. Acesso em: 03 nov. 2016. 
Lei $n^{\circ}$ 13.105, de 16 de março de 2015. Código de Processo Civil. Diário Oficial [da] República Federativa do Brasil, Brasília, DF, 17 mar. 2015.Disponível em: <https://www.planalto.gov.br/ccivil_03/_ato2015-2018/2015/lei/113105.htm>. Acesso em: 05 nov. 2016.

Câmara dos Deputados. Sua proposta pode virar lei. Disponível em:

<http://www2.camara.leg.br/participe/sua-proposta-pode-virar-lei $>$. Acesso em 08 out. 2016.

Controladoria Geral da União (CGU). Manual de Tomada de Contas Especial.

2013. Disponível em:

〈http://www.cgu.gov.br/ControleInterno/Arquivos/TomadaContasEspecial/ManualTCE.pdf $>$. Acesso em: 17 jul. 2015.

Planilha de processos remetidos ao Tribunal de Contas da União. Mar,

2014. Disponível em: <http://www.cgu.gov.br/assuntos/auditoria-e-fiscalizacao/avaliacao-dagestao-dos-administradores/tomadas-de-contas-especiais/realizacoes $>$. Acesso em: 16 jun. 2016.

Auditoria das Tomadas de Contas Especiais. Mar, 2014. Disponível em:

<http://www.cgu.gov.br/assuntos/auditoria-e-fiscalizacao/avaliacao-da-gestao-dosadministradores/tomadas-de-contas-especiais/realizacoes>. Acesso em: 2 ago. 2015.

Ministério da Fazenda. Ministério do Planejamento, Orçamento e Gestão. Portaria Interministerial $\mathrm{n}^{\circ}$ 507, de 24 de novembro de 2011. Estabelece normas para execução do disposto no Decreto ${ }^{\circ}$ 6.170, de 25 de julho de 2007, que dispõe sobre as normas relativas às transferências de recursos da União mediante convênios e contratos de repasse, revoga a Portaria Interministerial no 127/MP/MF/CGU, de 29 de maio de 2008 e dá outras providências. Diário Oficial [da] República Federativa do Brasil, Brasília, DF, 28 nov. 2011.Disponível em: <http://www.governoeletronico.gov.br/biblioteca/arquivos/portariainterministerial-no-507-de-24-de-novembro-de-2011/view>. Acesso em: 10 jul. 2015.

Gerência de Estudos Econômico-Fiscais. Sistema de Informações de Custos do Governo Federal (SIC): uma análise gerencial aplicada ao Programa Bolsa Família. [s.d]. Disponível em: 〈http://www.cepal.org/ofilac/noticias/paginas/3/43813/17_Gadelha.pdf>. Acesso em: 03 nov.2016.

Fundo Nacional de Saúde. Histórico. [s.d]. Disponível em:

$<$ http://www.fns.saude.gov.br/visao/carregarMenu.jsf;jsessionid=0E18C6A512CC525C0FB2 689CD586870A.server-portalfns-srvjpdf34?coMenu=8 >. Acesso em 26 jun.2016.

Relatório de auditoria anual de contas do Fundo Nacional de Saúde.

[s.d]. Disponível em: <http://sistemas2.cgu.gov.br/relats/uploads/RA201406322.pdf>. Acesso em: 2 ago. 2015.

Ministério da Fazenda. Secretaria do Tesouro Nacional. Cartilha Sistema de custos do governo federal. O que é? Para que serve? E como isso afeta meu dia a dia? Brasília, 2013. 
. Ministério da Saúde. Portaria GM nº 3.965, de 14 de dezembro de 2010. Aprova os Regimentos Internos dos órgãos do Ministério da Saúde. Diário Oficial [da] República Federativa do Brasil, Brasília, DF, 15 dez. 2010. Disponível em: $<$ http://bvsms.saude.gov.br/bvs/publicacoes/regimentos_internos_organogramas_basicos_ms. pdf $>$. Acesso em: $1^{\circ}$ ago. 2015.

Relatório de gestão do FNS 2011, 2012 e 2013. Disponível em: $\langle$ http://www.fns.saude.gov.br/visao/carregarMenu.jsf;jsessionid=4AB0BDC9230A65396 EDA84885D2ABEB2.server-portalfns-srvjpdf35?coMenu=13>. Acesso em: 2 ago. 2015.

Secretaria Executiva. Controle de endemias. Brasília, 2002.

Secretaria do Tesouro Nacional. Portaria n ${ }^{\circ} 157$ de 9 de março de 2011. Dispõe sobre a criação do Sistema de Custos do Governo Federal. Diário Oficial [da] República Federativa do Brasil, Brasília, DF, 10 mar. 2011a. Disponível em: $<$ http://www3.tesouro.gov.br/legislacao/download/contabilidade/PortSTN_157_09mar2011.p df $>$. Acesso em: 03 nov. 2016.

Portaria $\mathrm{n}^{\circ} 716$, de 24 de outubro de 2011. Dispõe sobre as competências dos Órgãos Central e Setoriais do Sistema de Custos do Governo Federal. Diário Oficial [da] República Federativa do Brasil, Brasília, DF, 25 out. 2011b. Disponível em:

$<$ http://www3.tesouro.gov.br/legislacao/download/PortSTN_7162011_Compet_SistCustos.pd f>. Acesso em: 03 nov. 2016.

Tribunal de Contas da União. Instrução normativa $\mathbf{n}^{\mathbf{0}} \mathbf{7 1}$, de 28 de novembro de 2012. Dispõe sobre a instauração, a organização e o encaminhamento ao Tribunal de Contas da União dos processos de tomada de contas especial. Brasília: 2012.

Acórdão no 1631/2009 - Plenário. Solicitação do Congresso Nacional.

Brasília: 2009. Disponível em: <judoc\%5CAcord\%5C20090724\%5C010-517-2008-4-AUD-

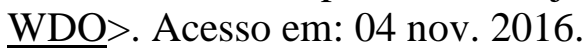

BRESSER-PEREIRA, Luiz Carlos. O modelo estrutural de gerência pública. Revista de Administração Pública, v. 42, n. 2, p. 391-410, 2008.

CAPOTE, Gart. Guia para formação de analistas de processos. Business Process Management. Rio de Janeiro: Bookess, 2011.

CARRARO, Beatriz Witt Haddad; ALLGAIER, Júlia Flach. Aplicação do sistema timedriven activity-based costing: um estudo de caso em uma microempresa do setor metalúrgico. XV Convenção de Contabilidade. Bento Gonçalves: 2015.

CASTELAR, Armando (org.). Judiciário e economia no Brasil. Rio de Janeiro, Centro Edelstein de Pesquisas Sociais, 2009. 
CATÂNIO, Antônio Ricardo; PIZZO, João Cláudio Machado; MORAES, Romildo de Oliveira. Time-Driven Activity-Based Costing (TDABC): um estudo bibliométrico das publicações nacionais. In: Anais do Congresso Brasileiro de Custos-ABC. 2015.

CONSELHO FEDERAL DE CONTABILIDADE (CFC). Normas brasileiras de contabilidade: contabilidade aplicada ao setor público: NBCs T 16.1 a 16.11. Brasília: Conselho Federal de Contabilidade, 2012.

CUNHA, Alexandre dos Santos et al. Custo unitário do processo de execução fiscal na Justiça Federal: relatório de pesquisa. Brasília: IPEA, 2011.

DALCI, Ilhan; TANIS, Veyis; KOSAN, Levent. Customer profitability analysis with timedriven activity-based costing: a case study in a hotel. International Journal of Contemporary Hospitality Management, v. 22, n. 5, p. 609-637, 2010.

DALMÁCIO, Flávia Záboli; REZENDE, Amaury José; AGUIAR, Andson Braga de. Uma aplicação do Time-Driven ABC Model no setor de serviço hospitalar: a nova abordagem do ABC proposta por Kaplan e Anderson. Contabilidade Vista \& Revista, v. 18, n. 2, p. 11-34, 2009.

DAWALIBI, Marcelo. Custeio de perícias na ação civil pública. In: MILARÉ, Édis. Ação civil pública após 30 anos. São Paulo: Editora Revista dos Tribunais, 2015.

DEMEERE, Nathalie; STOUTHUYSEN, Kristof; ROODHOOFT, Filip. Time-driven activity-based costing in an outpatient clinic environment: development, relevance and managerial impact. Health Policy, v. 92, n. 2, p. 296-304, 2009.

DIEHL, Carlos Alberto; SOUZA, Marcos Antônio de. Publicações sobre o Custeio Baseado em Atividades (ABC) em Congressos Brasileiros de Custos no Período de 1997 a 2006.

Contabilidade Vista \& Revista, v. 19, n. 4, p. 39-57, 2009.

; ALVES, Tiago Wickstron. Custeio Baseado em Atividades (ABC): um estudo sobre publicações em eventos científicos. Encontro da ANPAD, v. 32, 2008.

ELLIS-NEWMAN, Jennifer. Activity-based costing in user services of an academic library. Library Trends, v. 51, n. 3, p. 333-48, 2003.

EVERAERT, Patricia; BRUGGEMAN, Werner. Time-driven activity-based costing: exploring the underlying model. Journal of Cost Management, v. 21, n. 2, p. 16-20, 2007.

; SARENS, Gerrit; ANDERSON, Steven R.; LEVANT, Yves. Cost modeling in logistics using time-driven ABC: Experiences from a wholesaler. International Journal of Physical Distribution \& Logistics Management, v. 38, n. 3, p. 172-19, 2008.

FALQUETO, Júnia Maria Zandonade. A implantação do planejamento estratégico em universidades: o caso da Universidade de Brasília. 2012. 192f. Dissertação (Mestrado em Administração Pública). Faculdade de Economia, Administração e Contabilidade, Universidade de Brasília. Brasília: 2012. 
FINANCIAL ACCOUNTING STANDARDS BOARD (FASB). Statement of Federal Financial Accounting Standards $n^{\mathbf{0}}$ 4. Managerial Cost Accounting Standards and Concepts. Version 14. FASB, 1995.

FERNANDES, Jorge Ulisses Jacoby. Tomada de Contas Especial: processo e procedimento na Administração Pública e nos Tribunais de Contas. 6. ed. Revisada, atualizada e ampliada. Belo Horizonte: Fórum, 2015.

GÜNTHER, Hartmut. Como elaborar um relato de pesquisa. UnB, Laboratório de Psicologia Ambiental. Série: Planejamento de Pesquisa nas Ciências Sociais, nº 2, 2003.

GIAMBIAGI, Fabio; ALÉM, Ana Cláudia Duarte de. Finanças públicas: teoria e prática no Brasil. Rio de Janeiro: Elsevier Brasil, 2011.

HAIR JR., Joseph; BABIN, Barry; MONEY, Arthur; SAMOUEL, Philllip. Fundamentos de métodos de pesquisa em administração. Porto Alegre: Bookman, 2005.

HOLANDA, Victor Branco de; LATTMAN-WELTMAN, Fernando; GUIMARÃES, Fabrícia (orgs.). Sistema de informação de custos na Administração Pública Federal: uma política de estado. Rio de Janeiro: editora FGV, 2010.

KAPLAN, Robert; ANDERSON, Steven. Time-driven activity-based costing. Available at SSRN 485443, 2003.

KAPLAN, Robert S.; ANDERSON, Steven R. ABC: uma abordagem regida pelo tempo. Harvard Business Review, p. 130-36, 2004a.

KAPLAN, Robert; ANDERSON, Steven. Time-driven activity-based costing. Harvard Business Review, 2004b.

KAPLAN, Robert; ANDERSON, Steven. Custeio baseado em atividade e tempo. Rio de Janeiro: Elsevier, 2007.

LARKIN, Mary; RICHARDSON, Emma Louise; TABREMAN, Julia. New partnerships in health and social care for an era of public spending cuts. Health and Social Care in the Community, v. 20, n. 2, p. 199-207, 2012.

LEE, Ken; AUSTIN, Matthew; PRONOVOST, Peter. Developing a measure of value in health care. Article in press. Value in Health, 2014.

LEE, Sang-Soo; SALOLE, Eugene. Medical device reimbursement coverage and pricing rules in Korea: current practice and issues with access to innovation. Value in Health, v. 17, n. 4, p. 476-81, 2014.

; SYMONDS, Doug; KAMOGAWA, Sachiko; SATO, Mitsunobu; CHIANG, Emily; SALOLE, Eugene. Reimbursement Coverage and Pricing Systems for Single-Use Devices in 
Asia-Pacific: Japan, Taiwan, Korea, and Australia Compared. Value in Health Regional Issues, v. 6, p. 126-29, 2015.

LEONE, George Sebastião Guerra; PEDROSA, Carlos; PAULO, Edilson. Taxinomia dos sistemas de custeio e alocação de custos. RAUnP, v. 6, n. 1, p. 61-70, 2014.

LIMA, Eduardo Martins de; EMEDIATO, Renata Gomes. A participação popular no processo legislativo. Meritum, revista de Direito da Universidade FUMEC, v. 9, n. 1, 2014.

LONGO, Caricielli Maisa; LONGO, Marcelo Pereira. Acesso à justiça e custas judiciais: uma dicotomia. Colloquium Humanarum, p. 29-34, 2011.

LUDWIG, Antônio Carlos Will. Fundamentos e prática de metodologia científica. Vozes, 2009.

MACHADO, Nelson. Sistema de Informações de Custos: diretrizes para a integração ao orçamento público e à contabilidade governamental. 2002. $233 \mathrm{f}$. Tese (Doutorado em Controladoria e Contabilidade). Departamento de Contabilidade e Atuária, Universidade de São Paulo, São Paulo, 2002.

Sistema de Informação de Custo: diretrizes para integração ao orçamento público e à contabilidade governamental. Brasília: ENAP, 2005.

; HOLANDA, Vitor Branco de. Diretrizes e modelo conceitual de custos para o setor público a partir da experiência no governo federal do Brasil. Revista de Administração Pública, v. 44, n. 4, p. 791-820, 2010.

MAIA, Elton Azevedo; CARDOSO, Ricardo Lopes; BOTELHO, Delane; CARDOSO, Rosana Lopes. Contabilidade de custos e discriminação de preços entre clientes particulares e de planos de saúde: evidências de hospitais do município do Rio de Janeiro. Saúde em Debate, v. 33, n. 82, p. 222-33, 2009.

MARCONI, Marina de Andrade; LAKATOS, Eva Maria. Fundamentos de metodologia científica. 7. ed. São Paulo: Atlas, 2010.

MARTINS, Eliseu. Contabilidade de custos. 9. ed. São Paulo: Atlas, 2003.

MATIAS-PEREIRA, José. Administração Pública comparada: uma avaliação das reformas administrativas do Brasil, EUA e União Europeia. Revista de Administração Pública, v. 42, n. 1, p. 61-82, 2008.

MATOS, Lucas dos Santos; BERNARDO, Fabiano Domingos; BORGERT, Altair; ALBERTON, Luiz. A apuração dos custos do Serviço de Auditoria Federal do SUS na unidade descentralizada de Santa Catarina com base em um modelo estruturado de custeio.

Revista Gestão e Políticas Públicas, v. 3, n. 2, 2013. 
MEGLIORINI, Evandir. Custos: análise e gestão. 2. ed. São Paulo: Pearson Prentice Hall, 2006.

MONROY, Carlos Rodriguez; NASIRI, Azadeh; PELÁEZ, Miguel Ángel. Activity Based Costing, Time-Driven Activity Based Costing and Lean Accounting: Differences among three accounting systems' approach to manufacturing. In: Annals of Industrial Engineering 2012. Springer London, 2014. p. 11-17.

NAKAGAWA, Masayuki. ABC: custeio baseado em atividades. São Paulo: Atlas, 2001. NIVEIROS, Sofia Ines; RECH, Ilirio José; QUEIROS, Percival Ferreira; OLIVEIRA, Josemar Ribeiro de. Utilização do Custeio Baseado em Atividades (ABC) para o plantio de soja em uma propriedade localizada na região de Rondonópolis/MT. Rondonópolis/MT, Custos e @gronegócio online, v. 9, n. 1, 2013.

NORONHA, Marina; VERAS, Cláudia; LEITE, Iuri; MARTINS, Monica; BRAGA, Francisco; SILVER, Lynn. O desenvolvimento dos "Diagnosis Related Groups"-DRGs. Metodologia de classificação de pacientes hospitalares. Revista de Saúde Pública, v. 25, n. 3, p. 198-208, 1991.

OKLU, Rahmi; HAAS, Derek; KAPLAN, Robert; BRINEGAR, Katelyn; BASSOFF, Nicole; HARVEY, Benjamin; BRINK, James; PRABHAKAR, Anand. Time-Driven Activity-Based Costing in IR. Commentary. Journal of Vascular and Interventional Radiology 26, n. 12, p. 1827-31, 2015.

ORACLE, Sector Public. Federal Government Managerial Cost Accounting. An oracle white paper, dec. 2010. Disponível em: <http://www.oracle.com/us/solutions/businessintelligence/fed-gov-managerial-cost-accounting-254758.pdf>. Acesso em: 05 nov. 2016.

PERNOT, Eli; ROODHOOFT, Filip; VAN DEN ABBEELE, Alexandra. Time-driven activity-based costing for inter-library services: a case study in a university. The Journal of Academic Librarianship, v. 33, n. 5, p. 551-60, 2007.

QUINTÃO, Cynthia Magalhães Pinto Godoi; CARNEIRO, Ricardo. A tomada de contas especial como instrumento de controle e responsabilização. Revista de Administração Pública, v. 49, n. 2, p. 473-91, 2015.

REDDY, Kamil; VENTER, Hein; OLIVIER, Martin. Using time-driven activity-based costing to manage digital forensic readiness in large organizations. Information Systems Frontiers, v. 14, n. 5, p. 1061-77, 2012.

REEMBOLSO. In: DICIONÁRIO Aurélio online. Disponível em: < http://www. dicionariodoaurelio.com>. Acesso em 21 set. 2016, v. 6, 2010.

REZENDE, Flávio da Cunha. Teoria comparada e a economia política da expansão dos gastos públicos. Economia Aplicada, v. 12, n. 4, p. 607-33, 2008. 
REZENDE, Fernando; CUNHA, Armando; BEVILACQUA, Roberto. Informações de custos e qualidade do gasto público: lições da experiência internacional. Revista de Administração Pública, v. 44, n. 4, p. 959-92, 2010.

RIBEIRO, Márcio Bruno. Desempenho e eficiência do gasto público: uma análise comparativa entre o Brasil e um conjunto de países da América Latina. IPEA: Rio de Janeiro, 2008.

ROCHA, Bruno Fabrício Ferreira da. Governança em múltiplos níveis: análise do modelo de política fiscal brasileiro. 2015. 182f. Dissertação (Mestrado em Administração). Universidade de Brasília, Brasília, 2015.

RODRIGUES, Evaldo Zeferino; SILVA, Wendel Alex Castro; ARAÚJO, Elisson Alberto Tavares. Custeio Baseado em Atividade e Tempo-TDABC: estudo de caso em uma instituição de ensino superior particular. XIV Congresso USP Controladoria e Contabilidade, São Paulo 21 a 23 de julho de 2014. Disponível em: http://congressousp.fipecafi.org/web/artigos142014/391.pdf. Acesso em: 10 nov. 2016 SAMPIERI, Roberto Hernández; COLLADO, Carlos Fernández; LUCIO, Maria del Pilar Baptista. Metodologia de pesquisa. 3. ed. São Paulo: McGraw Hill, 2006.

SÁNCHEZ-MARTÍNEZ, Fernando; ABELLÁN-PERPIÑÁN, José-Maria; MARTÍNEZPÉREZ, Jorge-Eduardo; PUIG-JUNOY, Jaume. Cost accounting and public reimbursement schemes in spanish hospitals. Health Care Management Science, v. 9, n. 3, p. 225-32, 2006.

SCHMIDT, Paulo; SANTOS, José Luiz dos; LEAL, Ricardo. Time-driven activity based costing (TDABC): uma ferramenta evolutiva na gestão de atividades. Faculdade São Francisco de Assis (UNIFIN) Brasil: Rio Grande do Sul, 2009.

SCHOEPS, Wolfgang. O método do custeio direto. Revista de Administração de Empresas, v. 32, n. 3, p. 58-66. São Paulo: 1992.

SCHREYÖGG, Jonas; STARGARDT, Tom; TIEMANN, Oliver; BUSSE, Reinhard. Methods to determine reimbursement rates for diagnosis related groups (DRG): a comparison of nine European countries. Health Care Management Science, v. 9, n. 3, p. 215-23, 2006.

SECCHI, Leonardo. Modelos organizacionais e reformas da Administração Pública. Revista de Administração Pública, Rio de Janeiro, v. 43, n. 2, p. 347-69, 2009.

SILVA, Antônio Paulo da. Tomada de Contas Especial: uma medida de exceção no controle administrativo. Revista Controle, v. 8, n. 1, 2010.

SILVA, César Augusto Tibúrcio; MORGAN, Beatriz Fátima; COSTA, Patrícia de Souza. Desenvolvimento e aplicação de uma metodologia para cálculo do custo-aluno de instituições públicas de ensino superior: um estudo de caso. Revista de Administração Pública, v. 38, n. 2, p. 243-60, 2004.

Custos no setor público. Brasília: editora Universidade de Brasília, 2007. 
; MARINHO, Danilo Nolasco Cortes; WALTER, Maria Inez Machado Telles; SOUZA, Ludmila de Melo. Estudo de Custos do Sistema Nacional de Emprego - SINE. Ministério do Trabalho e Emprego e Universidade de Brasília. 2011.

SILVA, Lino Martins. Diretrizes para a elaboração de indicadores de custos no Governo Federal. Brasília, nov. 2011. Disponível em <http://www3.tesouro.fazenda.gov.br/Sistema_Informacao_custos/downloads/Diretrizes_Elab Indic_Custos_LinoMartins_VF.pdf>. Acesso em: 9 jul. 2015.

SOUZA, Antônio Artur; AVELAR, Ewerton Alex; BOINA, Terence Machado; CAIRES, Neiva Andrade. Aplicação do time-driven ABC em uma empresa varejista. ABCustos, v. 7, n. 2, p. 23-45, 2012.

SUZART, Janilson Antônio da Silva. Sistema federal brasileiro de custos: uma análise comparativa à luz das recomendações da IFAC. Revista de Gestão, Finanças e Contabilidade, v. 2, n. 3, p. 39-55, 2012. TEERAWATTANANON, Yot; TRITASAVIT, Nattha; SUCHONWANICH, Netnapis; KINGKAEW, Pritaporn. The use of economic evaluation for guiding the pharmaceutical reimbursement list in Thailand. Zeitschrift für Evidenz, Fortbildung und Qualität im Gesundheitswesen, v. 108, n. 7, p. 397-404, 2014.

THAMAE, Retselisitsoe I. The growth of government spending in Lesotho. Economic Analysis and Policy, v. 43, n. 3, p. 339-52, 2013.

VARTANIAN, Grigor Haig; NASCIMENTO, Diogo Toledo do. O Método de Custeio Pleno: Uma Abordagem Conceitual. In: Anais do Congresso Brasileiro de Custos-ABC. 1999.

VOGL, Matthias. Assessing DRG cost accounting with respect to resource allocation and tariff calculation: the case of Germany. Health Economics Review, v. 2, n. 1, p. 1, 2012.

WIEMER, Ana Paula Moreira; RIBEIRO, Daniel Cerqueira. Custos no serviço público. In: Congresso USP de Controladoria e Contabilidade, São Paulo, 2004. Disponível em: $<$ http://www.congressousp.fipecafi.org/web/artigos42004/187.pdf >. Acesso em: 2 ago. 2015.

YIN, Robert. K. Estudo de caso: planejamento e métodos. 4.ed, Porto Alegre: Bookman, 2010.

ZAMBON, Edson Pedro; ZORZO, Lucas Seffrin. Custeio baseado em atividades e tempo (TDABC): um estudo bibliométrico em congressos. Revista Científica FAZER, v. 2, n. 2, p. 1-17, 2014. 


\section{ANEXO}

\section{ANEXO A - Fluxograma do FNS}

Fluxograma elaborado pelo FNS para atender à área de informática, quanto à elaboração de um novo sistema.

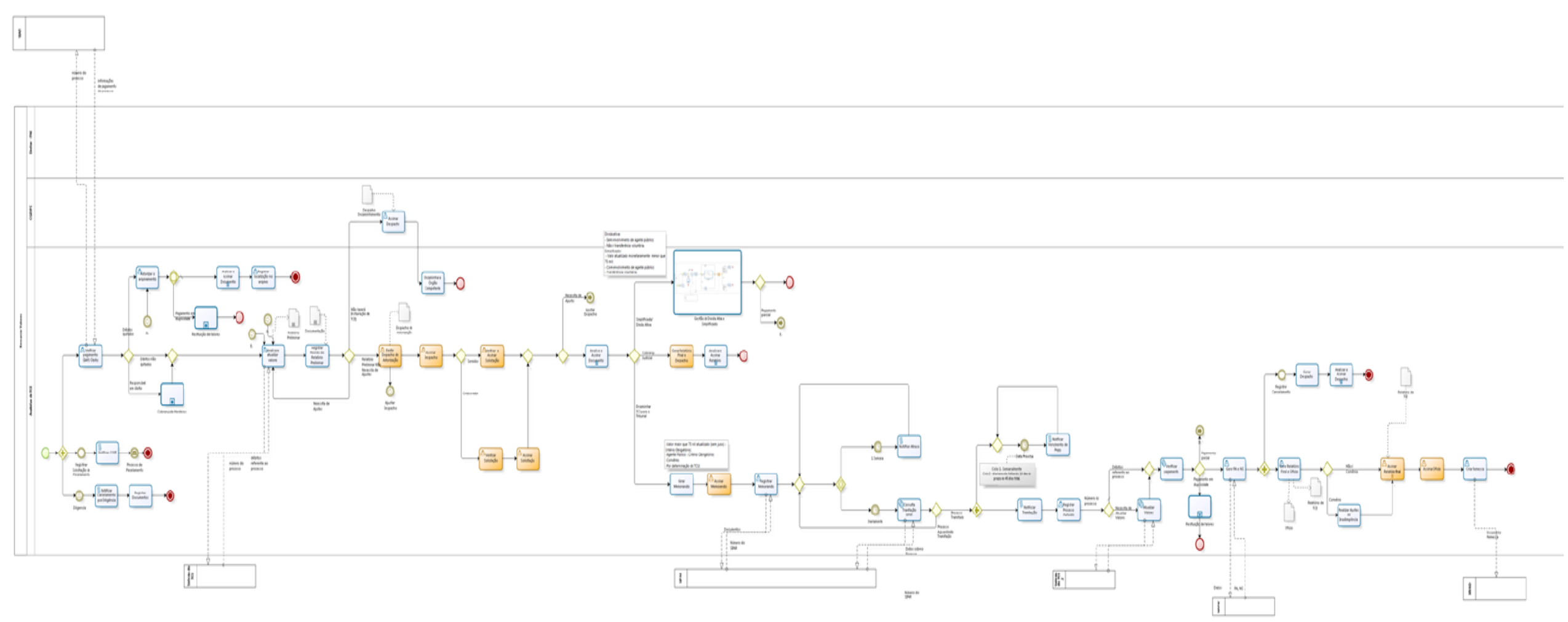




\section{APÊNDICES}

\section{APÊNDICE A - Adequação dos roteiros semiestruturados para realização das entrevistas}

Solicito a vossa contribuição como juiz, para adequação das perguntas constantes nos roteiros semiestruturados necessários para nortear a realização das entrevistas, listadas abaixo, a serem administrados junto aos participantes de um estudo, que tem como objetivo geral avaliar o custo do processo de Tomada de Contas Especial, viabilizando o reembolso para Administração Pública.

São 4 roteiros de entrevistas, tendo cada roteiro entre 9 e 16 perguntas, totalizando 48 perguntas.

Cada roteiro está alinhado a um objetivo específico, apresentados antes de cada roteiro, juntamente com o contexto que está inserido.

Para avaliação dos critérios de adequação de cada pergunta será utilizada uma escala, conforme se considera:

a) clareza da linguagem - tem como foco observar se o(a) senhor(a) considera suficientemente clara e adequada a linguagem de cada pergunta, sendo:

\section{pouco clara e inadequada $1 \quad 2 \quad 3 \quad 3 \quad 4 \quad 5$ suficientemente clara e adequada}

b) pertinência das perguntas - tem como foco observar se o(a) senhor(a) considera pertinente para o contexto pesquisado as perguntas propostas, sendo:

\section{pouco pertinente $1 \quad 2 \quad 3 \quad 4 \quad 5$ suficientemente pertinente}

c) relevância teórica - tem como foco observar se o(a) senhor(a) considera que o conteúdo da pergunta é pertinente ao estudo realizado, sendo:

\section{pouco pertinente $1 \quad 2 \quad 3 \quad 4 \quad 5$ suficientemente pertinente}

Há o campo de observação para informações adicionais, caso possa contribuir na melhoria das perguntas, que ficará ressaltada na cor vermelha.

Realizar as marcações substituindo a escala pela nota escolhida, da seguinte forma:

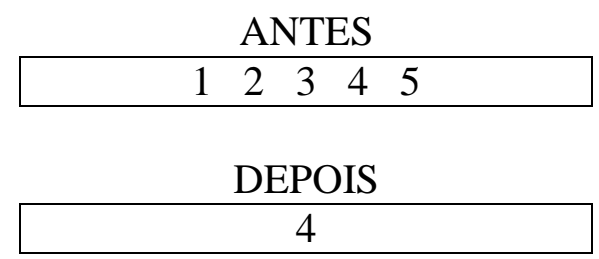

Vale registrar que apesar da solicitação de identificação do entrevistado, os dados serão mantidos em sigilo e será resguardado o aspecto ético da pesquisa.

Desde já agradeço a atenção e a contribuição. 


\section{ROTEIRO SEMIESTRUTURADO PARA ENTREVISTA Nº1}

Contexto do Roteiro: Objetiva obter dados e informações para elaboração do mapeamento do processo de TCE, sendo aplicada aos órgãos envolvidos em todas as etapas da fase interna, quais sejam a Coordenação de Contabilidade do Fundo Nacional de Saúde (CCONT/FNS), o setor de TCE da Controladoria Geral da União (CGU), a Assessoria de Controle Interno do Ministério da Saúde (AECI-MS) e Gabinete do Ministério da Saúde (GM-MS), tendo como respondente tanto os gestores quanto os analistas.

\begin{tabular}{|c|c|c|c|c|c|c|c|}
\hline CATEGORIA & ITEM & PERGUNTA & PARA QUE SERVE & $\begin{array}{c}\text { 1) CLAREZA } \\
\text { NA } \\
\text { LINGUAGEM }\end{array}$ & $\begin{array}{c}\text { 2) } \\
\text { PERTINÊNCIA } \\
\text { DAS } \\
\text { PERGUNTAS }\end{array}$ & $\begin{array}{c}\text { 3) } \\
\text { RELEVÂNCIA } \\
\text { TEÓRICA }\end{array}$ & OBSERVAÇÕES \\
\hline IDENTIFICAÇÃO & 1 & $\begin{array}{l}\text { Qual o seu nome, cargo } \\
\text { e as competências } \\
\text { atribuídas nesse cargo? }\end{array}$ & $\begin{array}{l}\text { Registrar as informações } \\
\text { básicas do entrevistado. }\end{array}$ & 12345 & 12345 & 12345 & \\
\hline IDENTIFICAÇÃO & 2 & $\begin{array}{l}\text { Tempo de atuação na } \\
\text { organização? }\end{array}$ & $\begin{array}{l}\text { Identificar o tempo de } \\
\text { atuação na organização. }\end{array}$ & 12345 & 12345 & 12345 & \\
\hline $\begin{array}{l}\text { ESTRUTURA } \\
\text { REGIMENTAL }\end{array}$ & 3 & $\begin{array}{l}\text { Quais os setores que o } \\
\text { processo de TCE } \\
\text { envolve? }\end{array}$ & $\begin{array}{l}\text { Identificar a estrutura } \\
\text { regimental e a } \\
\text { abrangência que está } \\
\text { inserido o processo. }\end{array}$ & 12345 & 12345 & 12345 & \\
\hline $\begin{array}{l}\text { ESTRUTURA } \\
\text { REGIMENTAL }\end{array}$ & 4 & $\begin{array}{l}\text { Quais unidades da } \\
\text { federação analisam os } \\
\text { processos de TCE? }\end{array}$ & $\begin{array}{l}\text { Identificar a estrutura } \\
\text { regimental e a } \\
\text { abrangência que está } \\
\text { inserido o processo. }\end{array}$ & 12345 & 12345 & 12345 & \\
\hline PESSOAL & 5 & $\begin{array}{l}\text { Qual o número de } \\
\text { servidores que atuam no } \\
\text { processo de TCE? }\end{array}$ & $\begin{array}{l}\text { Identificar a população } \\
\text { geral da pesquisa. }\end{array}$ & 12345 & 12345 & 12345 & \\
\hline $\begin{array}{l}\text { MAPEAMENTO DO } \\
\text { PROCESSO DE TCE }\end{array}$ & 6 & $\begin{array}{l}\text { Como é o processo de } \\
\text { trabalho para a } \\
\text { instauração da TCE? }\end{array}$ & $\begin{array}{l}\text { Identificar e inferir como } \\
\text { se processa as atividades. }\end{array}$ & 12345 & 12345 & 12345 & \\
\hline ATIVIDADES & 7 & $\begin{array}{l}\text { Trabalha apenas com } \\
\text { processos de TCE? }\end{array}$ & $\begin{array}{c}\text { Identificar a quantidade } \\
\text { de atividades que o } \\
\text { profissional está }\end{array}$ & 12345 & 12345 & 12345 & \\
\hline
\end{tabular}




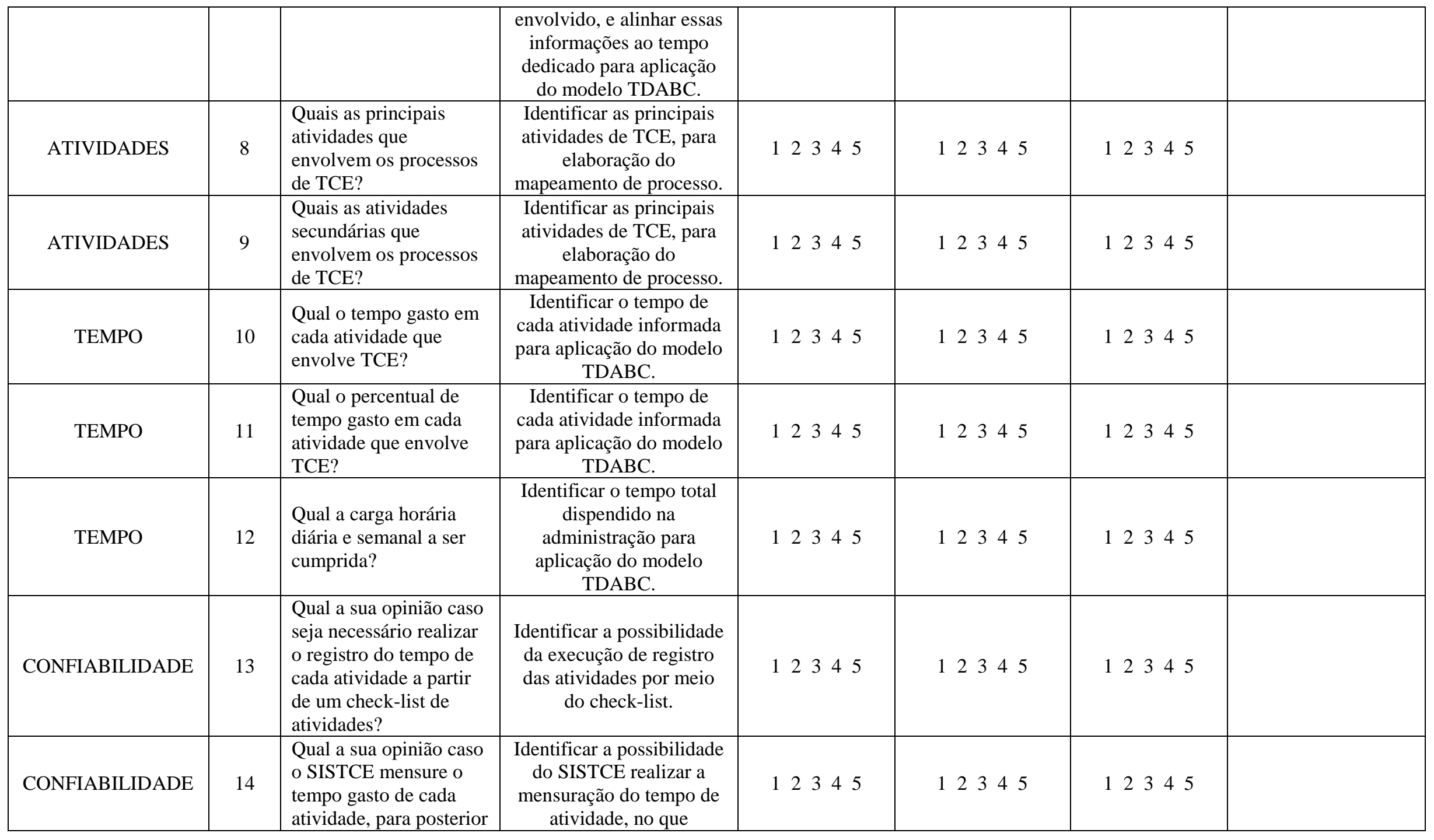




\begin{tabular}{|c|c|c|c|c|c|c|}
\hline & & $\begin{array}{l}\text { cálculo e cobrança do } \\
\text { valor do custo do } \\
\text { processo? }\end{array}$ & $\begin{array}{l}\text { concerne a confiabilidade } \\
\text { de realizar esse registro } \\
\text { para posterior cobrança do } \\
\text { responsável. }\end{array}$ & & & \\
\hline CONFIABILIDADE & 15 & $\begin{array}{l}\text { Além das duas } \\
\text { possibilidades acima, } \\
\text { como sugere que seja } \\
\text { feita a mensuração do } \\
\text { tempo gasto do } \\
\text { processo de TCE? }\end{array}$ & $\begin{array}{l}\text { Identificar outras formas } \\
\text { de registro de tempo das } \\
\text { atividades. }\end{array}$ & 12345 & 12345 & 12345 \\
\hline SISTEMA & 16 & $\begin{array}{l}\text { Considera viável fazer a } \\
\text { integração do SISTCE } \\
\text { com o SIC? }\end{array}$ & $\begin{array}{c}\text { Identificar a possibilidade } \\
\text { de integração entre os } \\
\text { sistemas }\end{array}$ & 12345 & 12345 & 12345 \\
\hline
\end{tabular}

\section{ROTEIRO SEMIESTRUTURADO PARA ENTREVISTA No 02}

Contexto do Roteiro: Objetiva obter dados quanto aos valores envolvidos no processo de TCE, sendo aplicada aos órgãos detentores dessa informação, quais sejam o Setor de Patrimônio do Fundo Nacional de Saúde (FNS) e Setor de Patrimônio da Controladoria Geral da União (CGU), tendo como respondente tanto o gestor quanto os analistas.

\begin{tabular}{|c|c|c|c|c|c|c|c|}
\hline CATEGORIA & ITEM & PERGUNTA & PARA QUE SERVE & $\begin{array}{c}\text { 1) CLAREZA } \\
\text { NA } \\
\text { LINGUAGEM }\end{array}$ & $\begin{array}{c}\text { 2) } \\
\text { PERTINÊNCIA } \\
\text { DAS } \\
\text { PERGUNTAS }\end{array}$ & $\begin{array}{c}\text { 3) } \\
\text { RELEVÂNCIA } \\
\text { TEÓRICA }\end{array}$ & OBSERVAÇÕES \\
\hline CUSTOS & 1 & $\begin{array}{l}\text { Qual a tamanho do } \\
\text { espaço disponível para } \\
\text { o desempenho das } \\
\text { atividades de TCE? }\end{array}$ & $\begin{array}{c}\text { Identificar o tamanho do } \\
\text { espaço disponível para os } \\
\text { setores que atuam no } \\
\text { processo de TCE, para } \\
\text { aplicar no modelo } \\
\text { TDABC. } \\
\end{array}$ & 12345 & 12345 & 12345 & \\
\hline CUSTOS & 2 & $\begin{array}{l}\text { Qual a remuneração } \\
\text { de todos os } \\
\text { colaboradores que }\end{array}$ & $\begin{array}{l}\text { Identificar o custo total } \\
\text { com mão de obra para o } \\
\text { desempenho das }\end{array}$ & 12345 & 12345 & 12345 & \\
\hline
\end{tabular}




\begin{tabular}{|c|c|c|c|c|c|c|c|}
\hline & & $\begin{array}{l}\text { trabalham com a } \\
\text { análise dos processos } \\
\text { de TCE, nos últimos } \\
12 \text { meses? }\end{array}$ & $\begin{array}{l}\text { atividades de TCE, para } \\
\text { aplicar no modelo } \\
\text { TDABC. }\end{array}$ & & & & \\
\hline CUSTOS & 3 & $\begin{array}{l}\text { Qual o valor gasto } \\
\text { com materiais } \\
\text { administrativos e de } \\
\text { expediente pelas áreas } \\
\text { que trabalham com } \\
\text { TCE, nos últimos } 12 \\
\text { meses? }\end{array}$ & $\begin{array}{l}\text { Identificar o custo com } \\
\text { materiais administrativos } \\
\text { e de expediente pelas } \\
\text { áreas que trabalham com } \\
\text { TCE, para aplicar no } \\
\text { modelo TDABC. }\end{array}$ & 12345 & 12345 & 12345 & \\
\hline CUSTOS & 4 & $\begin{array}{l}\text { Qual o valor gasto } \\
\text { com serviços de } \\
\text { terceiros pelas áreas } \\
\text { que trabalham com } \\
\text { processos de TCE, nos } \\
\text { últimos } 12 \text { meses? }\end{array}$ & $\begin{array}{l}\text { Identificar o custo com } \\
\text { serviços de terceiros pelas } \\
\text { áreas que trabalham com } \\
\text { TCE, para aplicar no } \\
\text { modelo TDABC. }\end{array}$ & 12345 & 12345 & 12345 & \\
\hline CUSTOS & 5 & $\begin{array}{l}\text { Qual o valor gasto } \\
\text { com serviço de } \\
\text { manutenção pelas } \\
\text { áreas que trabalham } \\
\text { com processos de } \\
\text { TCE, nos últimos } 12 \\
\text { meses? }\end{array}$ & $\begin{array}{c}\text { Identificar o custo com } \\
\text { serviços de manutenção } \\
\text { pelas áreas que trabalham } \\
\text { com TCE, para aplicar no } \\
\text { modelo TDABC. }\end{array}$ & 12345 & 12345 & 12345 & \\
\hline CUSTOS & 6 & $\begin{array}{l}\text { Qual o valor gasto } \\
\text { com telefonia pelas } \\
\text { áreas que trabalham } \\
\text { com TCE, nos últimos } \\
12 \text { meses? }\end{array}$ & $\begin{array}{c}\text { Identificar o custo com } \\
\text { serviços de telefonia pelas } \\
\text { áreas que trabalham com } \\
\text { TCE, para aplicar no } \\
\text { modelo TDABC. }\end{array}$ & 12345 & 12345 & 12345 & \\
\hline CUSTOS & 7 & $\begin{array}{l}\text { Qual o valor gasto } \\
\text { com água pelas áreas } \\
\text { que trabalham com } \\
\text { TCE, nos últimos } 12 \\
\text { meses? }\end{array}$ & $\begin{array}{l}\text { Identificar o custo com } \\
\text { água pelas áreas que } \\
\text { trabalham com TCE, para } \\
\text { aplicar no modelo } \\
\text { TDABC. }\end{array}$ & 12345 & 12345 & 12345 & \\
\hline
\end{tabular}




\begin{tabular}{|c|c|c|c|c|c|c|}
\hline CUSTOS & 8 & $\begin{array}{l}\text { Qual o valor gasto } \\
\text { com energia pelas } \\
\text { áreas que trabalham } \\
\text { com processos de } \\
\text { TCE? }\end{array}$ & $\begin{array}{l}\text { Identificar o custo com } \\
\text { energia elétrica pelas } \\
\text { áreas que trabalham com } \\
\text { TCE, para aplicar no } \\
\text { modelo TDABC. }\end{array}$ & 12345 & 12345 & 12345 \\
\hline CUSTOS & 9 & $\begin{array}{l}\text { Qual o valor gasto } \\
\text { com Aluguel/ } \\
\text { depreciação pelas } \\
\text { áreas que trabalham } \\
\text { com processos de } \\
\text { TCE, nos últimos } 12 \\
\text { meses? }\end{array}$ & $\begin{array}{l}\text { Identificar o custo com } \\
\text { aluguel/ depreciação pelas } \\
\text { áreas que trabalham com } \\
\text { TCE, para aplicar no } \\
\text { modelo TDABC. }\end{array}$ & 12345 & 12345 & 12345 \\
\hline CUSTOS & 10 & $\begin{array}{l}\text { Qual o valor gasto } \\
\text { com serviços de } \\
\text { informática pelas } \\
\text { áreas que trabalham } \\
\text { com processos de } \\
\text { TCE, nos últimos } 12 \\
\text { meses? }\end{array}$ & $\begin{array}{c}\text { Identificar o custo com } \\
\text { serviços de informática } \\
\text { pelas áreas que trabalham } \\
\text { com TCE, para aplicar no } \\
\text { modelo TDABC. }\end{array}$ & 12345 & 12345 & 12345 \\
\hline CONFIABILIDADE & 11 & $\begin{array}{l}\text { Qual o sistema que } \\
\text { disponibiliza esses } \\
\text { dados? }\end{array}$ & $\begin{array}{l}\text { Identificar a fonte da } \\
\text { informação. }\end{array}$ & 12345 & 12345 & 12345 \\
\hline CONFIABILIDADE & 12 & $\begin{array}{l}\text { Os dados estão } \\
\text { disponíveis para } \\
\text { consulta pública? }\end{array}$ & $\begin{array}{l}\text { Identificar o local físico } \\
\text { ou digital disponível para } \\
\text { obter as informações. }\end{array}$ & 12345 & 12345 & 12345 \\
\hline
\end{tabular}

\section{ROTEIRO SEMIESTRUTURADO PARA ENTREVISTA No 03}

Contexto do Roteiro: Objetiva obter orientações e informações acerca do Sistema de Informações de Custos do Governo Federal (SIC), sendo aplicado a Secretaria do Tesouro Nacional (STN), que é gestora do sistema, e ao órgão seccional de custos do Ministério da Saúde que é a Coordenação de Monitoramento de Custos (CMC), tendo como respondente um gestor de cada setor.

Objetivo específico no3: Sugerir adaptação ao Sistema de Informações de Custos do Governo Federal (SIC) para apuração do custo dos processos de TCE. 


\begin{tabular}{|c|c|c|c|c|c|c|c|}
\hline CATEGORIA & ITEM & PERGUNTA & PARA QUE SERVE & $\begin{array}{c}\text { 1) CLAREZA } \\
\text { NA } \\
\text { LINGUAGEM }\end{array}$ & $\begin{array}{c}\text { 2) } \\
\text { PERTINÊNCIA } \\
\text { DAS } \\
\text { PERGUNTAS }\end{array}$ & $\begin{array}{c}\text { 3) } \\
\text { RELEVÂNCIA } \\
\text { TEÓRICA }\end{array}$ & OBSERVAÇÕES \\
\hline IDENTIFICAÇÃO & 1 & $\begin{array}{l}\text { Qual o seu nome, } \\
\text { cargo e as atividades } \\
\text { que desempenha em } \\
\text { relação ao SIC? }\end{array}$ & $\begin{array}{l}\text { Registrar as informações } \\
\text { básicas do entrevistado. }\end{array}$ & 12345 & 12345 & 12345 & \\
\hline IDENTIFICAÇÃO & 2 & $\begin{array}{l}\text { Qual o tempo de } \\
\text { atuação na } \\
\text { organização? }\end{array}$ & $\begin{array}{l}\text { Identificar o tempo de } \\
\text { atuação na organização. }\end{array}$ & 12345 & 12345 & 12345 & \\
\hline PESSOAL & 3 & $\begin{array}{l}\text { Quantas pessoas } \\
\text { trabalham no setor? }\end{array}$ & $\begin{array}{l}\text { Identificar a população } \\
\text { geral da pesquisa. }\end{array}$ & 12345 & 12345 & 12345 & \\
\hline $\begin{array}{l}\text { ACESSO AO } \\
\text { SISTEMA }\end{array}$ & 4 & $\begin{array}{l}\text { Quais os requisitos de } \\
\text { acesso ao SIC? }\end{array}$ & $\begin{array}{c}\text { Ter conhecimento de } \\
\text { como pode ter acesso ao } \\
\text { sistema }\end{array}$ & 12345 & 12345 & 12345 & \\
\hline $\begin{array}{l}\text { ACESSO AO } \\
\text { SISTEMA }\end{array}$ & 5 & $\begin{array}{l}\text { Como funciona o SIC, } \\
\text { no enfoque } \\
\text { operacional? }\end{array}$ & $\begin{array}{l}\text { Identificar maneiras para } \\
\text { operacionalizar e ter } \\
\text { acesso aos dados }\end{array}$ & 12345 & 12345 & 12345 & \\
\hline $\begin{array}{l}\text { ACESSO AO } \\
\text { SISTEMA }\end{array}$ & 6 & $\begin{array}{l}\text { Quais os principais } \\
\text { problemas enfrentados } \\
\text { para o uso do sistema? }\end{array}$ & $\begin{array}{c}\text { Identificar possíveis } \\
\text { limitações, a } \\
\text { vulnerabilidade e avaliar } \\
\text { se haverá impacto para o } \\
\text { acesso ao sistema. } \\
\end{array}$ & 12345 & 12345 & 12345 & \\
\hline DADOS & 7 & $\begin{array}{l}\text { Até que nível de } \\
\text { detalhamento os dados } \\
\text { sobre custos são } \\
\text { disponibilizados no } \\
\text { SIC? }\end{array}$ & $\begin{array}{l}\text { Ter conhecimento até que } \\
\text { nível de detalhamento } \\
\text { pode se obter os dados. }\end{array}$ & 12345 & 12345 & 12345 & \\
\hline DADOS & 8 & $\begin{array}{l}\text { Quais os níveis de } \\
\text { acesso ao SIC. Caso } \\
\text { um servidor não tenha } \\
\text { acesso ao SIAPE, por } \\
\text { exemplo, os dados } \\
\text { relacionados aos }\end{array}$ & $\begin{array}{c}\text { Identificar as possíveis } \\
\text { limitações de acesso aos } \\
\text { dados. }\end{array}$ & 12345 & 12345 & 12345 & \\
\hline
\end{tabular}




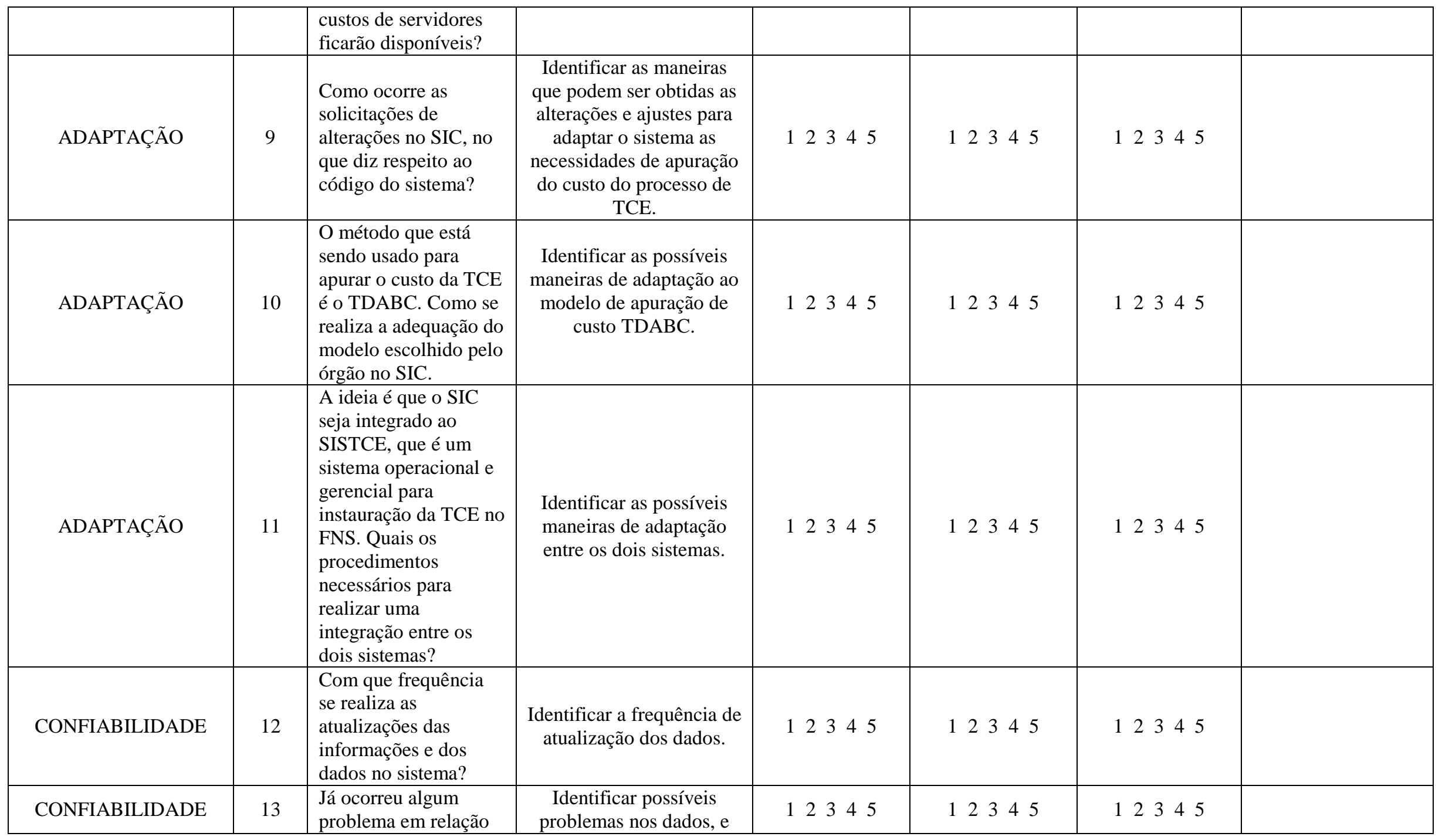




\begin{tabular}{|l|l|l|l|l|l|l|}
\hline & $\begin{array}{l}\text { aos dados fornecidos } \\
\text { pelo SIC? }\end{array}$ & $\begin{array}{c}\text { avaliar a intensidade do } \\
\text { impacto no cálculo do } \\
\text { custo do processo de } \\
\text { TCE. }\end{array}$ & & & \\
\hline
\end{tabular}

\section{ROTEIRO SEMIESTRUTURADO PARA ENTREVISTA No 04}

Contexto do Roteiro: Objetiva obter a opinião das áreas envolvidas no processo de TCE quanto a pertinência da cobrança do valor do custo do processo de TCE e quais os requisitos para o início da cobrança, sendo aplicada aos órgãos envolvidos no processo, quais sejam, Ministério da Saúde (MS), Controladoria Geral da União (CGU), Tribunal de Contas da União (TCU), Ministério Público junto ao TCU (MP-TCU), Advocacia Geral da União (AGU), tendo como respondente, Advogado Geral da União, gestores e analistas.

\begin{tabular}{|c|c|c|c|c|c|c|c|}
\hline CATEGORIA & ITEM & PERGUNTA & PARA QUE SERVE & $\begin{array}{c}\text { 1) CLAREZA } \\
\text { NA } \\
\text { LINGUAGEM }\end{array}$ & $\begin{array}{c}\text { 2) } \\
\text { PERTINÊNCIA } \\
\text { DAS } \\
\text { PERGUNTAS } \\
\end{array}$ & $\begin{array}{c}\text { 3) } \\
\text { RELEVÂNCIA } \\
\text { TEÓRICA }\end{array}$ & OBSERVAÇÕES \\
\hline IDENTIFICAÇÃO & 1 & $\begin{array}{l}\text { Qual o cargo e as } \\
\text { atribuições que } \\
\text { desempenha em } \\
\text { relação a cobrança dos } \\
\text { processos de TCE? }\end{array}$ & JÁ AVALIADA & $\begin{array}{c}\text { JÁ } \\
\text { AVALIADA }\end{array}$ & JÁ AVALIADA & JÁ AVALIADA & \\
\hline IDENTIFICAÇÃO & 2 & $\begin{array}{l}\text { Tempo de atuação na } \\
\text { organização? }\end{array}$ & JÁ AVALIADA & $\begin{array}{c}\text { JÁ } \\
\text { AVALIADA } \\
\end{array}$ & JÁ AVALIADA & JÁ AVALIADA & \\
\hline LEGITIMIDADE & 3 & $\begin{array}{l}\text { Considera pertinente a } \\
\text { cobrança dos valores } \\
\text { referente ao custo } \\
\text { despendido pela } \\
\text { Administração Pública } \\
\text { para instauração do }\end{array}$ & $\begin{array}{l}\text { Identificar a opinião em } \\
\text { relação à cobrança do } \\
\text { valor do custo do } \\
\text { processo de TCE aos } \\
\text { responsáveis apontados } \\
\text { no processo de TCE. }\end{array}$ & 12345 & 12345 & 12345 & \\
\hline
\end{tabular}




\begin{tabular}{|c|c|c|c|c|c|c|c|}
\hline & & $\begin{array}{l}\text { processo de TCE, que } \\
\text { é um medida } \\
\text { excepcional adotada } \\
\text { pela Administração? }\end{array}$ & & & & & \\
\hline LEGITIMIDADE & 4 & $\begin{array}{l}\text { EM CASO } \\
\text { NEGATIVO: } \\
\text { Por quê? }\end{array}$ & $\begin{array}{l}\text { Identificar o motivo da } \\
\text { inviabilidade da cobrança } \\
\text { do valor do custo do } \\
\text { processo de TCE aos } \\
\text { responsáveis. }\end{array}$ & 12345 & 12345 & 12345 & \\
\hline LEGITIMIDADE & 5 & $\begin{array}{l}\text { EM CASO POSITIVO: } \\
\text { Considera que pode } \\
\text { haver } \\
\text { questionamentos } \\
\text { adversos referente a } \\
\text { essa cobrança? Quais? }\end{array}$ & $\begin{array}{l}\text { Identificar os possíveis } \\
\text { motivos que impeçam de } \\
\text { dar continuidade à } \\
\text { cobrança do custo do } \\
\text { processo de TCE, e } \\
\text { avaliar quais os possíveis } \\
\text { motivos. }\end{array}$ & 12345 & 12345 & 12345 & \\
\hline LEGITIMIDADE & 6 & $\begin{array}{l}\text { Levando em } \\
\text { consideração o } \\
\text { aspecto da apuração } \\
\text { do valor, é suficiente } \\
\text { que seja realizada por } \\
\text { meio de uma } \\
\text { metodologia, baseado } \\
\text { em um modelo que } \\
\text { leva em consideração } \\
\text { o tempo despendido } \\
\text { para instauração, não } \\
\text { tendo um valor fixo, } \\
\text { mas que foi validado } \\
\text { por profissionais de } \\
\text { reconhecido } \\
\text { conhecimento na área } \\
\text { e calculado por um } \\
\text { sistema } \\
\text { governamental que }\end{array}$ & $\begin{array}{l}\text { Identificar a opinião em } \\
\text { relação ao método de } \\
\text { custeio utilizado para a } \\
\text { cobrança do valor do } \\
\text { custo do processo de TCE } \\
\text { aos responsáveis } \\
\text { apontados no processo de } \\
\text { TCE. }\end{array}$ & 12345 & 12345 & 12345 & \\
\hline
\end{tabular}




\begin{tabular}{|c|c|c|c|c|c|c|}
\hline & & \begin{tabular}{|l|} 
demonstra \\
transparência?
\end{tabular} & & & & \\
\hline LEGITIMIDADE & 7 & $\begin{array}{l}\text { EM CASO } \\
\text { NEGATIVO: } \\
\text { Por que? }\end{array}$ & $\begin{array}{c}\text { Identificar a opinião em } \\
\text { relação a limitação para o } \\
\text { cálculo do custo do } \\
\text { processo de TCE aos } \\
\text { responsáveis pelo } \\
\text { TDABC. }\end{array}$ & 12345 & 12345 & $\begin{array}{llll}12345 \\
\end{array}$ \\
\hline LEGITIMIDADE & 8 & $\begin{array}{l}\text { O que seria necessário } \\
\text { além disso? }\end{array}$ & $\begin{array}{c}\text { Identificar outros } \\
\text { aspectos que podem ser } \\
\text { levados em consideração } \\
\text { para realizar a cobrança } \\
\text { do custo do processo de } \\
\text { TCE. } \\
\end{array}$ & 12345 & 12345 & 12345 \\
\hline NORMATIZAÇÃO & 9 & $\begin{array}{l}\text { Qual o instrumento } \\
\text { normativo que } \\
\text { considera necessário } \\
\text { para estabelecer o } \\
\text { início da cobrança? }\end{array}$ & $\begin{array}{c}\text { Identificar quais os meios } \\
\text { que podem ser usados } \\
\text { para normatizar e tornar } \\
\text { eficaz o início da } \\
\text { cobrança. }\end{array}$ & 12345 & 12345 & 12345 \\
\hline
\end{tabular}




\section{APÊNDICE B - Resultado da avaliação dos Roteiros de Entrevista}

Correlação entre a nota de cada juiz para cada questão, com a média das notas recebidas. As questões foram avaliadas em critérios de clareza da linguagem, pertinência da pergunta e relevância teórica, dentro do contexto de cada roteiro semiestruturado de entrevista.

\section{Roteiro de Entrevista $n^{\circ} 01$}

\begin{tabular}{|c|c|c|c|c|c|c|}
\hline \multirow{5}{*}{1} & \multirow[t]{2}{*}{ Questão: } & \multicolumn{5}{|c|}{ Qual o seu nome, cargo e as competências atribuídas nesse cargo? } \\
\hline & & A & B & $\mathrm{C}$ & MÉDIA & OBSERVAÇÕES \\
\hline & Clareza na linguagem & 5 & 3 & 4 & 4,00 & \multirow{3}{*}{$\begin{array}{l}\text { - E se a pessoa quiser ficar anônima? Seria interessante para o projeto? Ou precisa da identificação } \\
\text { mesmo? } \\
\text { - Conceituar competências. }\end{array}$} \\
\hline & Pertinência da pergunta & 1 & 5 & 5 & 3,67 & \\
\hline & Relevância teórica & 1 & 5 & 5 & 3,67 & \\
\hline \multirow{5}{*}{2} & Questão: & \multicolumn{5}{|c|}{ Qual o tempo de atuação na organização? } \\
\hline & Juízes & A & $\mathrm{B}$ & $\mathrm{C}$ & MÉDIA & OBSERVAÇÕES \\
\hline & Clareza na linguagem & 5 & 3 & 4 & 4,00 & \multirow{3}{*}{$\begin{array}{l}\text { - Houve algum emprego anterior? } \\
\text { - Esse emprego converge com o atual? } \\
\text { - SUGESTÃO: Qual o tempo de atuação na organização e com processos de TCE? }\end{array}$} \\
\hline & Pertinência da pergunta & 5 & 5 & 5 & 5,00 & \\
\hline & Relevância teórica & 5 & 5 & 5 & 5,00 & \\
\hline \multirow{5}{*}{3} & Questão: & \multicolumn{5}{|c|}{ Quais os setores que o processo de TCE envolve? } \\
\hline & Juízes & A & $\mathrm{B}$ & $\mathrm{C}$ & MÉDIA & OBSERVAÇÕES \\
\hline & Clareza na linguagem & 5 & 3 & 4 & 4,00 & \multirow{3}{*}{ - O cargo que ocupa permite saber os setores que o TCE passa? } \\
\hline & Pertinência da pergunta & 5 & 4 & 5 & 4,67 & \\
\hline & Relevância teórica & 5 & 4 & 5 & 4,67 & \\
\hline \multirow{3}{*}{4} & Questão: & \multicolumn{5}{|c|}{ Quais unidades da federação analisam os processos de TCE? } \\
\hline & Juízes & $\mathrm{A}$ & $\mathrm{B}$ & $\mathrm{C}$ & MÉDIA & OBSERVAÇÕES \\
\hline & Clareza na linguagem & 5 & 3 & 5 & 4,33 & \\
\hline
\end{tabular}




\begin{tabular}{|c|c|c|c|c|c|c|}
\hline \multirow{2}{*}{4} & Pertinência da pergunta & 5 & 3 & 5 & 4,33 & \\
\hline & Relevância teórica & 5 & 3 & 4 & 4,00 & \\
\hline \multirow{5}{*}{5} & Questão: & \multicolumn{5}{|c|}{ Qual o número de servidores que atuam no processo de TCE? } \\
\hline & Juízes & A & B & $\mathrm{C}$ & MÉDIA & OBSERVAÇÕES \\
\hline & Clareza na linguagem & 5 & 3 & 4 & 4,00 & \multirow{3}{*}{ - Eles tem como saber essa resposta? } \\
\hline & Pertinência da pergunta & 5 & 3 & 5 & 4,33 & \\
\hline & Relevância teórica & 5 & 3 & 5 & 4,33 & \\
\hline \multirow{5}{*}{ ( } & Questão: & \multicolumn{5}{|c|}{ Como é o processo de trabalho para a instauração da TCE? } \\
\hline & Juízes & A & B & $\mathrm{C}$ & MÉDIA & OBSERVAÇÕES \\
\hline & Clareza na linguagem & 5 & 3 & 5 & 4,33 & \multirow{3}{*}{$\begin{array}{l}\text { - Conceituar processo de trabalho. } \\
\text { - SUGESTÃO: Quais as etapas do trabalho para a instauração da TCE? }\end{array}$} \\
\hline & Pertinência da pergunta & 5 & 3 & 5 & 4,33 & \\
\hline & Relevância teórica & 5 & 3 & 5 & 4,33 & \\
\hline \multirow{5}{*}{7} & Questão: & \multicolumn{5}{|c|}{ Trabalha apenas com processos de TCE? } \\
\hline & Juízes & A & $\mathrm{B}$ & $\mathrm{C}$ & MÉDIA & OBSERVAÇÕES \\
\hline & Clareza na linguagem & 5 & 4 & 5 & 4,67 & \\
\hline & Pertinência da pergunta & 5 & 4 & 5 & 4,67 & \\
\hline & Relevância teórica & 5 & 5 & 5 & 5,00 & \\
\hline \multirow{5}{*}{8} & Questão: & \multicolumn{5}{|c|}{ Quais as principais atividades que envolvem os processos de TCE? } \\
\hline & Juízes & A & B & $\mathrm{C}$ & MÉDIA & OBSERVAÇÕES \\
\hline & Clareza na linguagem & 5 & 4 & 5 & 4,67 & \\
\hline & Pertinência da pergunta & 5 & 4 & 5 & 4,67 & \\
\hline & Relevância teórica & 5 & 5 & 5 & 5,00 & \\
\hline \multirow{4}{*}{9} & Questão: & \multicolumn{5}{|c|}{ Quais as atividades secundárias que envolvem os processos de TCE? } \\
\hline & Juízes & A & B & $\mathrm{C}$ & MÉDIA & OBSERVAÇÕES \\
\hline & Clareza na linguagem & 5 & 4 & 5 & 4,67 & \\
\hline & Pertinência da pergunta & 5 & 4 & 5 & 4,67 & \\
\hline
\end{tabular}




\begin{tabular}{|c|c|c|c|c|c|c|}
\hline & Relevância teórica & 5 & 5 & 5 & 5,00 & \\
\hline \multirow{5}{*}{10} & Questão: & \multicolumn{5}{|c|}{ Qual o tempo gasto em cada atividade que envolve TCE? } \\
\hline & Juízes & A & $\mathrm{B}$ & $\mathrm{C}$ & MÉDIA & OBSERVAÇÕES \\
\hline & Clareza na linguagem & 4 & 4 & 5 & 4,33 & \multirow{3}{*}{ - SUGESTÃO: Qual o tempo médio que é gasto em cada atividade que envolve TCE? } \\
\hline & Pertinência da pergunta & 5 & 4 & 5 & 4,67 & \\
\hline & Relevância teórica & 5 & 4 & 5 & 4,67 & \\
\hline \multirow{5}{*}{11} & Questão: & \multicolumn{5}{|c|}{ Qual o percentual de tempo gasto em cada atividade que envolve TCE? } \\
\hline & Juízes & A & $\mathrm{B}$ & $\mathrm{C}$ & MÉDIA & OBSERVAÇÕES \\
\hline & Clareza na linguagem & 4 & 2 & 3 & 3,00 & \\
\hline & Pertinência da pergunta & 5 & 2 & 5 & 4,00 & \\
\hline & Relevância teórica & 5 & 2 & 5 & 4,00 & \\
\hline \multirow{3}{*}{12} & Questão: & \multicolumn{5}{|c|}{ Qual a carga horária diária e semanal a ser cumprida? } \\
\hline & \begin{tabular}{|l|l|l} 
Juízes \\
\end{tabular} & A & $\mathrm{B}$ & $\mathrm{C}$ & MÉDIA & OBSERVAÇÕES \\
\hline & Clareza na linguagem & 4 & 2 & 5 & 3,67 & \\
\hline \multirow{2}{*}{12} & Pertinência da pergunta & 5 & 4 & 5 & 4,67 & \\
\hline & Relevância teórica & 5 & 5 & 5 & 5,00 & \\
\hline \multirow{5}{*}{13} & Questão: & \multicolumn{5}{|c|}{ Qual a sua opinião caso seja necessário realizar o registro do tempo de cada atividade a partir de um check-list de atividades? } \\
\hline & \begin{tabular}{|l|} 
Juízes \\
\end{tabular} & $\mathrm{A}$ & $\mathrm{B}$ & $\mathrm{C}$ & MÉDIA & OBSERVAÇÕES \\
\hline & Clareza na linguagem & 5 & 3 & 4 & 4,00 & \multirow{3}{*}{$\begin{array}{l}\text { - Essa pergunta poderia estar na posição } 10 \text { e a } 10,11 \text { e } 12 \text { só se o gestor for a favor do registro de } \\
\text { tempo para cada atividade separadamente. } \\
\text { - Não entendo se esta atividade contribuiria significativamente }\end{array}$} \\
\hline & Pertinência da pergunta & 5 & 3 & 5 & 4,33 & \\
\hline & Relevância teórica & 5 & 3 & 5 & 4,33 & \\
\hline \multirow{4}{*}{14} & Questão: & \multicolumn{5}{|c|}{$\begin{array}{l}\text { Qual a sua opinião caso o SISTCE mensure o tempo gasto de cada atividade, para posterior cálculo e cobrança do valor do custo do } \\
\text { processo? }\end{array}$} \\
\hline & \begin{tabular}{|l|} 
Juízes \\
\end{tabular} & A & $\mathrm{B}$ & $\mathrm{C}$ & MÉDIA & OBSERVAÇÕES \\
\hline & Clareza na linguagem & 5 & 4 & 3 & 4,00 & \multirow{2}{*}{$\begin{array}{l}\text { - Essa pergunta poderia estar na posição } 10 \text { e a } 10,11 \text { e } 12 \text { só se o gestor for a favor do registro de } \\
\text { tempo para cada atividade separadamente. }\end{array}$} \\
\hline & Pertinência da pergunta & 5 & 4 & 4 & 4,33 & \\
\hline
\end{tabular}




\begin{tabular}{|c|c|c|c|c|c|c|}
\hline & Relevância teórica & 5 & 4 & 4 & 4,33 & \\
\hline \multirow{5}{*}{15} & Questão: & \multicolumn{5}{|c|}{ Além das duas possibilidades acima, como sugere que seja feita a mensuração do tempo gasto do processo de TCE? } \\
\hline & Juízes & A & B & $\mathrm{C}$ & MÉDIA & OBSERVAÇÕES \\
\hline & Clareza na linguagem & 5 & 3 & 3 & 3,67 & \\
\hline & Pertinência da pergunta & 5 & 3 & 4 & 4,00 & \\
\hline & Relevância teórica & 5 & 3 & 5 & 4,33 & \\
\hline \multirow{5}{*}{16} & Questão: & \multicolumn{5}{|c|}{ Considera viável fazer a integração do SISTCE com o SIC? } \\
\hline & Juízes & A & B & $\mathrm{C}$ & MÉDIA & OBSERVAÇÕES \\
\hline & Clareza na linguagem & 5 & 3 & 5 & 4,33 & \multirow{3}{*}{$\begin{array}{l}\text { - SUGESTÃO: Considera viável fazer a integração do SISTCE com o Sistema de Informações de } \\
\text { Custos do Governo Federal? }\end{array}$} \\
\hline & Pertinência da pergunta & 5 & 3 & 5 & 4,33 & \\
\hline & Relevância teórica & 5 & 3 & 5 & 4,33 & \\
\hline
\end{tabular}

\section{Roteiro de Entrevista $n^{o} 02$}

\begin{tabular}{|c|c|c|c|c|c|c|}
\hline \multirow{5}{*}{1} & \multirow[t]{2}{*}{ Questão: } & \multicolumn{5}{|c|}{ Qual a tamanho do espaço disponível para o desempenho das atividades de TCE? } \\
\hline & & A & $\mathrm{B}$ & $\mathrm{C}$ & MÉDIA & OBSERVAÇÕES \\
\hline & Clareza na linguagem & 2 & 3 & 4 & 3,00 & \multirow{3}{*}{$\begin{array}{l}\text { - A pergunta não ficou clara para mim. Como assim tamanho do espaço disponível? } \\
\text { - SUGESTÃO: Qual o tamanho do espaço disponível para o desempenho das atividades de análise dos } \\
\text { processos de TCE? }\end{array}$} \\
\hline & Pertinência da pergunta & 5 & 3 & 4 & 4,00 & \\
\hline & Relevância teórica & 5 & 3 & 4 & 4,00 & \\
\hline \multirow{5}{*}{2} & Questão: & \multicolumn{5}{|c|}{ Qual a remuneração de todos os colaboradores que trabalham com a análise dos processos de TCE, nos últimos 12 meses? } \\
\hline & Juízes & A & B & $\mathrm{C}$ & MÉDIA & OBSERVAÇÕES \\
\hline & Clareza na linguagem & 5 & 4 & 5 & 4,67 & \multirow{3}{*}{$\begin{array}{l}\text { - Apesar da pergunta ser claro, quem vai saber o valor com materiais, energia, água, etc? } \\
\text { - Tem como saber? }\end{array}$} \\
\hline & Pertinência da pergunta & 5 & 4 & 5 & 4,67 & \\
\hline & Relevância teórica & 5 & 4 & 5 & 4,67 & \\
\hline
\end{tabular}




\begin{tabular}{|c|c|c|c|c|c|c|}
\hline \multirow{5}{*}{3} & Questão: & \multicolumn{5}{|c|}{ Qual o valor gasto com materiais administrativos e de expediente pelas áreas que trabalham com TCE, nos últimos 12 meses? } \\
\hline & Juízes & A & B & $\mathrm{C}$ & MÉDIA & OBSERVAÇÕES \\
\hline & Clareza na linguagem & 5 & 4 & 4 & 4,33 & \multirow{3}{*}{ Onde? } \\
\hline & Pertinência da pergunta & 5 & 4 & 4 & 4,33 & \\
\hline & Relevância teórica & 5 & 4 & 4 & 4,33 & \\
\hline \multirow{5}{*}{4} & Questão: & \multicolumn{5}{|c|}{ Qual o valor gasto com serviços de terceiros pelas áreas que trabalham com processos de TCE, nos últimos 12 meses? } \\
\hline & Juízes & A & B & $\mathrm{C}$ & MÉDIA & OBSERVAÇÕES \\
\hline & Clareza na linguagem & 5 & 4 & 5 & 4,67 & \\
\hline & Pertinência da pergunta & 5 & 4 & 5 & 4,67 & \\
\hline & Relevância teórica & 5 & 4 & 5 & 4,67 & \\
\hline \multirow{5}{*}{5} & Questão: & \multicolumn{5}{|c|}{ Qual o valor gasto com serviço de manutenção pelas áreas que trabalham com processos de TCE, nos últimos 12 meses? } \\
\hline & Juízes & A & B & $\mathrm{C}$ & MÉDIA & OBSERVAÇÕES \\
\hline & Clareza na linguagem & 5 & 4 & 5 & 4,67 & \\
\hline & Pertinência da pergunta & 5 & 4 & 5 & 4,67 & \\
\hline & Relevância teórica & 5 & 4 & 5 & 4,67 & \\
\hline \multirow{5}{*}{6} & Questão: & \multicolumn{5}{|c|}{ Qual o valor gasto com telefonia pelas áreas que trabalham com TCE, nos últimos 12 meses? } \\
\hline & Juízes & A & $\mathrm{B}$ & $\mathrm{C}$ & MÉDIA & OBSERVAÇÕES \\
\hline & Clareza na linguagem & 5 & 4 & 5 & 4,67 & \\
\hline & Pertinência da pergunta & 5 & 4 & 5 & 4,67 & \\
\hline & Relevância teórica & 5 & 4 & 5 & 4,67 & \\
\hline \multirow{5}{*}{7} & Questão: & \multicolumn{5}{|c|}{ Qual o valor gasto com água pelas áreas que trabalham com TCE, nos últimos 12 meses? } \\
\hline & Juízes & A & $\mathrm{B}$ & $\mathrm{C}$ & MÉDIA & OBSERVAÇÕES \\
\hline & Clareza na linguagem & 5 & 4 & 5 & 4,67 & \\
\hline & Pertinência da pergunta & 5 & 4 & 5 & 4,67 & \\
\hline & Relevância teórica & 5 & 4 & 5 & 4,67 & \\
\hline
\end{tabular}




\begin{tabular}{|c|c|c|c|c|c|c|}
\hline \multirow{5}{*}{8} & \multirow[t]{2}{*}{ Questão: } & \multicolumn{5}{|c|}{ Qual o valor gasto com energia pelas áreas que trabalham com processos de TCE? } \\
\hline & & A & B & $\mathrm{C}$ & MÉDIA & OBSERVAÇÕES \\
\hline & Clareza na linguagem & 5 & 4 & 5 & 4,67 & \multirow{3}{*}{$\begin{array}{l}\text { - SUGESTÃO: Qual o valor gasto com energia elétrica pelas áreas que trabalham com processos de } \\
\text { TCE? }\end{array}$} \\
\hline & Pertinência da pergunta & 5 & 4 & 5 & 4,67 & \\
\hline & Relevância teórica & 5 & 4 & 5 & 4,67 & \\
\hline \multirow{5}{*}{9} & Questão: & \multicolumn{5}{|c|}{ Qual o valor gasto com Aluguel/depreciação pelas áreas que trabalham com processos de TCE, nos últimos 12 meses? } \\
\hline & Juízes & A & $\mathrm{B}$ & $\mathrm{C}$ & MÉDIA & OBSERVAÇÕES \\
\hline & Clareza na linguagem & 5 & 4 & 5 & 4,67 & \multirow{3}{*}{$\begin{array}{l}\text { - Incluir manutenção? } \\
\text { - Aluguel/manutenção/depreciação? }\end{array}$} \\
\hline & Pertinência da pergunta & 5 & 4 & 5 & 4,67 & \\
\hline & Relevância teórica & 5 & 4 & 5 & 4,67 & \\
\hline \multirow{5}{*}{10} & Questão: & \multicolumn{5}{|c|}{ Qual o valor gasto com serviços de informática pelas áreas que trabalham com processos de TCE, nos últimos 12 meses? } \\
\hline & Juízes & A & $\mathrm{B}$ & $\mathrm{C}$ & MÉDIA & OBSERVAÇÕES \\
\hline & Clareza na linguagem & 5 & 4 & 5 & 4,67 & \\
\hline & Pertinência da pergunta & 5 & 4 & 5 & 4,67 & \\
\hline & Relevância teórica & 5 & 4 & 5 & 4,67 & \\
\hline \multirow{5}{*}{11} & Questão: & \multicolumn{5}{|c|}{ Qual o sistema que disponibiliza esses dados? } \\
\hline & Juízes & A & $\mathrm{B}$ & $\mathrm{C}$ & MÉDIA & OBSERVAÇÕES \\
\hline & Clareza na linguagem & 5 & 4 & 5 & 4,67 & \\
\hline & Pertinência da pergunta & 5 & 4 & 5 & 4,67 & \\
\hline & Relevância teórica & 5 & 4 & 5 & 4,67 & \\
\hline \multirow{5}{*}{12} & Questão: & \multicolumn{5}{|c|}{ Os dados estão disponíveis para consulta pública? } \\
\hline & Juízes & A & $\mathrm{B}$ & $\mathrm{C}$ & MÉDIA & OBSERVAÇÕES \\
\hline & Clareza na linguagem & 4 & 4 & 5 & 4,33 & \\
\hline & Pertinência da pergunta & 5 & 4 & 5 & 4,67 & \\
\hline & Relevância teórica & 5 & 4 & 5 & 4,67 & \\
\hline
\end{tabular}




\section{Roteiro de Entrevista $n^{o} 03$}

\begin{tabular}{|c|c|c|c|c|c|c|}
\hline \multirow{5}{*}{4} & \multirow[t]{2}{*}{ Questão: } & \multicolumn{5}{|c|}{ Quais os requisitos de acesso ao SIC? } \\
\hline & & A & B & $\mathrm{C}$ & MÉDIA & OBSERVAÇÕES \\
\hline & Clareza na linguagem & 5 & 4 & 4 & 4,33 & \multirow{3}{*}{ 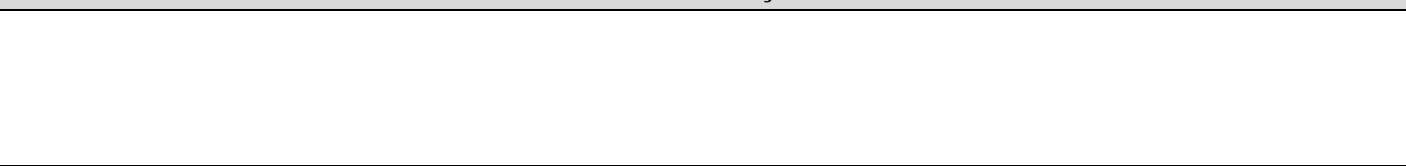 } \\
\hline & Pertinência da pergunta & 5 & 4 & 5 & 4,67 & \\
\hline & Relevância teórica & 5 & 4 & 5 & 4,67 & \\
\hline \multirow{5}{*}{5} & Questão: & \multicolumn{5}{|c|}{ Como funciona o SIC, no enfoque operacional? } \\
\hline & Juízes & $\mathrm{A}$ & $\mathrm{B}$ & $\mathrm{C}$ & MÉDIA & OBSERVAÇÕES \\
\hline & Clareza na linguagem & 5 & 4 & 4 & 4,33 & \multirow{3}{*}{ 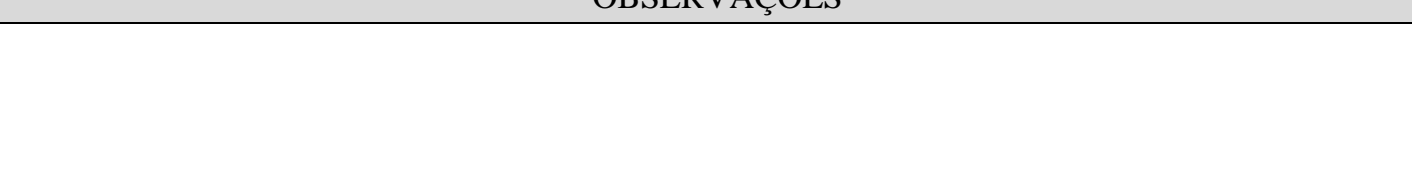 } \\
\hline & \multirow{2}{*}{\begin{tabular}{|l|} 
Pertinência da pergunta \\
Relevância teórica
\end{tabular}} & 5 & 4 & 5 & 4,67 & \\
\hline & & 5 & 4 & 5 & 4,67 & \\
\hline \multicolumn{2}{|r|}{ Questão: } & \multicolumn{5}{|c|}{ Quais os principais problemas enfrentados para o uso do sistema? } \\
\hline \multirow{4}{*}{6} & Juízes & A & $\mathrm{B}$ & $\mathrm{C}$ & MÉDIA & OBSERVAÇÕES \\
\hline & Clareza na linguagem & 5 & 4 & 4 & 4,33 & \multirow{3}{*}{ Tem como sugerir alternativas de resolução? } \\
\hline & Pertinência da pergunta & 5 & 4 & 5 & 4,67 & \\
\hline & Relevância teórica & 5 & 4 & 5 & 4,67 & \\
\hline \multirow{5}{*}{7} & Questão: & \multicolumn{5}{|c|}{ Até que nível de detalhamento os dados sobre custos são disponibilizados no SIC? } \\
\hline & Juízes & A & $\mathrm{B}$ & $\mathrm{C}$ & MÉDIA & OBSERVAÇÕES \\
\hline & Clareza na linguagem & 5 & 4 & 4 & 4,33 & \\
\hline & Pertinência da pergunta & 5 & 4 & 5 & 4,67 & \\
\hline & Relevância teórica & 5 & 4 & 5 & 4,67 & \\
\hline \multirow{5}{*}{8} & Questão: & \multicolumn{5}{|c|}{$\begin{array}{l}\text { Quais os níveis de acesso ao SIC. Caso um servidor não tenha acesso ao SIAPE, por exemplo, os dados relacionados aos custos de servidores } \\
\text { ficarão disponíveis? }\end{array}$} \\
\hline & Juízes & A & B & $\mathrm{C}$ & MÉDIA & OBSERVAÇÕES \\
\hline & Clareza na linguagem & 5 & 4 & 4 & 4,33 & \\
\hline & Pertinência da pergunta & 5 & 4 & 5 & 4,67 & \\
\hline & Relevância teórica & 5 & 4 & 5 & 4,67 & \\
\hline
\end{tabular}




\begin{tabular}{|c|c|c|c|c|c|c|}
\hline \multirow{5}{*}{9} & \multirow[t]{2}{*}{ Questão: } & \multicolumn{5}{|c|}{ Como ocorre as solicitações de alterações no SIC, no que diz respeito ao código do sistema? } \\
\hline & & A & $\mathrm{B}$ & $\mathrm{C}$ & MÉDIA & OBSERVAÇÕES \\
\hline & Clareza na linguagem & 3 & 4 & 5 & 4,00 & \multirow{3}{*}{ Alteração de que? } \\
\hline & Pertinência da pergunta & 4 & 4 & 5 & 4,33 & \\
\hline & Relevância teórica & 4 & 4 & 4 & 4,00 & \\
\hline \multirow{5}{*}{10} & Questão: & \multicolumn{5}{|c|}{$\begin{array}{l}\text { O método que está sendo usado para apurar o custo da TCE é o TDABC. Como se realiza a adequação do modelo escolhido pelo órgão no } \\
\text { SIC. }\end{array}$} \\
\hline & Juízes & A & $\mathrm{B}$ & $\mathrm{C}$ & MÉDIA & OBSERVAÇÕES \\
\hline & Clareza na linguagem & 5 & 4 & 5 & 4,67 & \\
\hline & Pertinência da pergunta & 5 & 4 & 5 & 4,67 & \\
\hline & Relevância teórica & 5 & 4 & 5 & 4,67 & \\
\hline \multirow{5}{*}{11} & Questão: & \multicolumn{5}{|c|}{$\begin{array}{l}\text { A ideia é que o SIC seja integrado ao SISTCE, que é um sistema operacional e gerencial para instauração da TCE no FNS. Quais os } \\
\text { procedimentos necessários para realizar uma integração entre os dois sistemas? }\end{array}$} \\
\hline & Juízes & A & $\mathrm{B}$ & $\mathrm{C}$ & MÉDIA & OBSERVAÇÕES \\
\hline & Clareza na linguagem & 5 & 4 & 4 & 4,33 & \\
\hline & Pertinência da pergunta & 5 & 4 & 5 & 4,67 & \\
\hline & Relevância teórica & 5 & 4 & 5 & 4,67 & \\
\hline \multirow{5}{*}{12} & Questão: & \multicolumn{5}{|c|}{ Com que frequência se realiza as atualizações das informações e dos dados no sistema? } \\
\hline & Juízes & $\mathrm{A}$ & $\mathrm{B}$ & $\mathrm{C}$ & MÉDIA & OBSERVAÇÕES \\
\hline & Clareza na linguagem & 5 & 5 & 4 & 4,67 & \\
\hline & Pertinência da pergunta & 5 & 5 & 5 & 5,00 & \\
\hline & Relevância teórica & 5 & 4 & 5 & 4,67 & \\
\hline \multirow{5}{*}{13} & Questão: & \multicolumn{5}{|c|}{ Já ocorreu algum problema em relação aos dados fornecidos pelo SIC? } \\
\hline & Juízes & $\mathrm{A}$ & $\mathrm{B}$ & $\mathrm{C}$ & MÉDIA & OBSERVAÇÕES \\
\hline & Clareza na linguagem & 5 & 4 & 4 & 4,33 & \\
\hline & Pertinência da pergunta & 5 & 4 & 5 & 4,67 & \\
\hline & Relevância teórica & 5 & 4 & 5 & 4,67 & \\
\hline
\end{tabular}




\section{Roteiro de Entrevista n ${ }^{\circ} 04$}

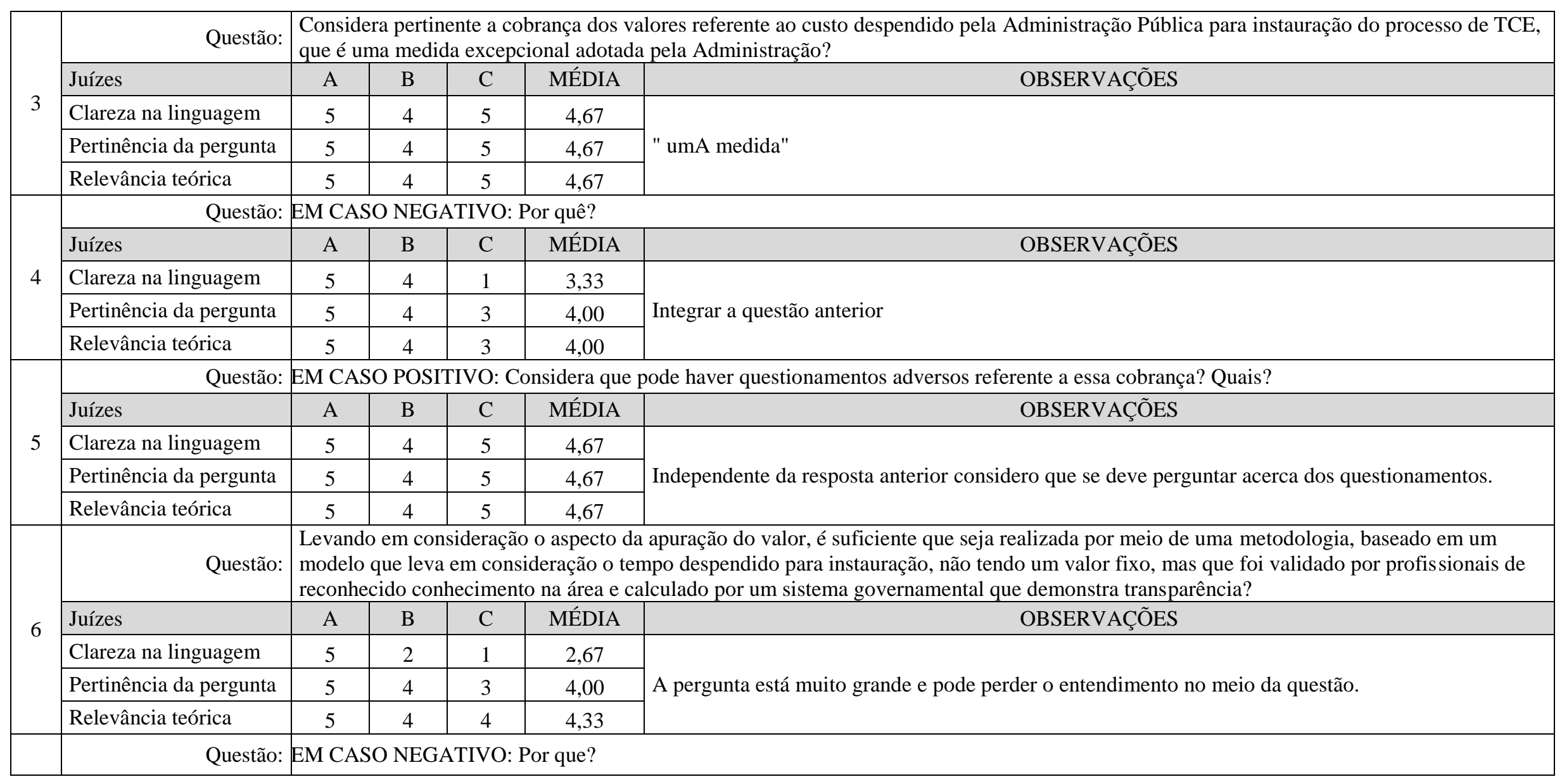




\begin{tabular}{|c|c|c|c|c|c|c|}
\hline \multirow{4}{*}{7} & Juízes & A & B & $\mathrm{C}$ & MÉDIA & OBSERVAÇÕES \\
\hline & Clareza na linguagem & 5 & 2 & 1 & 2,67 & \multirow{3}{*}{ Remeter o questionamento a questão anterior e eliminar essa. } \\
\hline & \begin{tabular}{|l|} 
Pertinência da pergunta \\
\end{tabular} & 5 & 4 & 2 & 3,67 & \\
\hline & Relevância teórica & 5 & 4 & 3 & 4,00 & \\
\hline \multirow{5}{*}{8} & Questão: & O que & a ne & irio & disso? & \\
\hline & Juízes & A & B & $\mathrm{C}$ & MÉDIA & OBSERVAÇÕES \\
\hline & Clareza na linguagem & 5 & 2 & 1 & 2,67 & \multirow{3}{*}{ Considero desnecessária. Eliminar } \\
\hline & Pertinência da pergunta & 5 & 3 & 2 & 3,33 & \\
\hline & Relevância teórica & 5 & 3 & 2 & 3,33 & \\
\hline \multirow{5}{*}{9} & Questão: & Qual c & trun & nor & ivo que co & idera necessário para estabelecer o início cobrança? \\
\hline & Juízes & A & $\mathrm{B}$ & $\mathrm{C}$ & MÉDIA & OBSERVAÇÕES \\
\hline & Clareza na linguagem & 5 & 3 & 5 & 4,33 & \multirow{3}{*}{$\begin{array}{l}\text { Esta pergunta está sendo influenciada pela pergunta } 6 \text { e } 7 \text { ? } \\
\text { As limitações que se referem nada têm com o início da cobrança? }\end{array}$} \\
\hline & Pertinência da pergunta & 5 & 3 & 5 & 4,33 & \\
\hline & Relevância teórica & 5 & 3 & 5 & 4,33 & \\
\hline
\end{tabular}




\section{APÊNDICE C - Cálculo dos objetos de gastos do setor}

Para o cálculo dos objetos de gastos da CCONT/FNS, foram considerados os dados relacionados a área útil de cada unidade do MS em Brasília/DF, assim como a quantidade de pessoas que trabalham em cada uma dessas unidades, dados estes obtidos junto ao Sistema de Informação ao Cidadão (SIC), disponível na Tabela 1. Todos os dados apresentados nesse apêndice são referentes ao primeiro semestre do ano de 2016.

Tabela 1 - Quantitativo de área útil e postos de trabalho do MS

\begin{tabular}{l|c|c|c}
\hline \multicolumn{1}{c|}{ Unidade do MS } & $\begin{array}{c}\text { Área Útil } \\
\left(\mathrm{m}^{2}\right)\end{array}$ & $\begin{array}{c}\text { Postos de } \\
\text { trabalho }\end{array}$ & $\begin{array}{c}\text { Quantidade de espaço disponível por posto de } \\
\text { trabalho (m² posto de trabalho) }\end{array}$ \\
\hline Premium & 8.589 & 1.542 & 5,57 \\
\hline Setor Comercial Sul & 4.044 & 393 & 10,29 \\
\hline Setor Comercial Norte & 2.433 & 299 & 8,13 \\
\hline Sede & 10.476 & 1.562 & 6,70 \\
\hline Anexo & 12.340 & 1.589 & 7,76 \\
\hline 510 Norte & 4.874 & 225 & 21,66 \\
\hline \multicolumn{1}{c}{ TOTAL } & 42.756 & 5.610 & 7,62 \\
\hline
\end{tabular}

Fonte: Elaborado pela autora com base nos dados fornecidos pelo Sistema de Informação ao Cidadão (SIC)

Além disso, os valores monetários considerados para a apuração relacionados a serviços de terceiros, telefonia, água, energia elétrica, aluguel/ depreciação, conforme as informações obtidas a partir do Entrevistado 3, são valores líquidos, após a retenção e recolhimento de tributos na fonte, conforme detalhado a seguir.

\section{Colaboradores}

Em relação a apuração dos objetos de gastos do setor referente a força de trabalho, foi levado em consideração a média do período dos primeiros 6 meses do ano, especificamente o período de janeiro a junho de 2016.

Os colaboradores da CCONT/FNS são compostos pelas chefias, servidores e bolsistas. Os dados referentes à remuneração básica bruta referente as chefias e aos servidores foram obtidos a partir de consulta ao site do portal da transparência, sendo considerado o valor monetário informado no campo "remuneração básica bruta" e dos bolsistas, a partir de consulta com a área responsável pela gestão desses profissionais. 
Esses dados podem ser considerados como salários percebidos pelos servidores e bolsistas, não sendo considerado os custos que a entidade tem com tais colaboradores.

A lista completa dos valores está disponível na Tabela 2

Tabela 2 - Colaboradores (valores em reais $\mathrm{R} \$$ )

\begin{tabular}{c|c|c|c|c|c|c|c}
\hline JAN & FEV & MAR & ABR & MAI & JUN & QNT & $\begin{array}{c}\text { MÉDIA } \\
\text { DOS } \\
\text { ULTIMOS } 6 \\
\text { MESES }\end{array}$ \\
\hline $10.871,99$ & $10.871,99$ & $10.871,99$ & $10.871,99$ & $10.871,99$ & $10.871,99$ & 1 & $10.871,99$ \\
\hline $2.837,53$ & $2.837,53$ & $2.837,53$ & $2.837,53$ & $2.837,53$ & $2.837,53$ & 1 & $2.837,53$ \\
\hline $3.861,98$ & $3.861,98$ & $3.861,98$ & $3.861,98$ & $3.861,98$ & $3.861,98$ & 1 & $3.861,98$ \\
\hline $4.252,58$ & $4.252,58$ & $4.252,58$ & $4.252,58$ & $4.252,58$ & $4.252,58$ & 1 & $4.252,58$ \\
\hline $4.281,15$ & $4.281,15$ & $4.281,15$ & $4.281,15$ & $4.281,15$ & $4.281,15$ & 1 & $4.281,15$ \\
\hline $8.376,35$ & $8.376,35$ & $8.376,35$ & $8.376,35$ & $8.376,35$ & $8.376,35$ & 1 & $8.376,35$ \\
\hline $8.376,35$ & $8.376,35$ & $8.732,81$ & $8.376,35$ & $8.643,69$ & $8.376,35$ & 1 & $8.480,32$ \\
\hline $8.376,35$ & $8.376,35$ & $8.376,35$ & $8.376,35$ & $8.376,35$ & $8.376,35$ & 1 & $8.376,35$ \\
\hline $8.198,67$ & $8.198,67$ & $8.198,67$ & $8.198,67$ & $8.198,67$ & $8.198,67$ & 1 & $8.198,67$ \\
\hline $8.198,67$ & $8.198,67$ & $8.198,67$ & $8.198,67$ & $8.198,67$ & $8.198,67$ & 1 & $8.198,67$ \\
\hline $9.713,06$ & $9.713,06$ & $9.713,06$ & $9.713,06$ & $8.465,46$ & $8.376,35$ & 1 & $9.282,34$ \\
\hline $8.376,35$ & $8.376,35$ & $8.376,35$ & $8.376,35$ & $8.376,35$ & $8.376,35$ & 1 & $8.376,35$ \\
\hline $8.198,67$ & $8.198,67$ & $8.198,67$ & $8.198,67$ & $8.198,67$ & $8.198,67$ & 1 & $8.198,67$ \\
\hline $5.495,41$ & $5.495,41$ & $5.495,41$ & $5.495,41$ & $5.495,41$ & $5.495,41$ & 1 & $5.495,41$ \\
\hline $5.778,00$ & $5.778,00$ & $5.778,00$ & $5.778,00$ & $5.778,00$ & $5.778,00$ & 1 & $5.778,00$ \\
\hline $5.778,00$ & $5.778,00$ & $5.778,00$ & $5.778,00$ & $5.778,00$ & $5.778,00$ & 1 & $5.778,00$ \\
\hline $5.500,00$ & $5.500,00$ & $5.500,00$ & $5.500,00$ & $5.500,00$ & $5.500,00$ & 1 & $5.500,00$ \\
\hline $6.741,00$ & $6.741,00$ & $6.741,00$ & $6.741,00$ & $6.741,00$ & $6.741,00$ & 1 & $6.741,00$ \\
\hline $6.290,00$ & $6.290,00$ & $6.290,00$ & $6.290,00$ & $6.290,00$ & $6.290,00$ & 1 & $6.290,00$ \\
\hline $6.163,20$ & $6.163,20$ & $6.163,20$ & $6.163,20$ & $6.163,20$ & $6.163,20$ & 1 & $6.163,20$ \\
\hline $6.259,50$ & $6.259,50$ & $6.259,50$ & $6.259,50$ & $6.259,50$ & $6.259,50$ & 1 & $6.259,50$ \\
\hline & & & & & & 21 & $141.598,06$ \\
\hline
\end{tabular}

Fonte: Elaborado pela autora, com base nos dados disponíveis no Portal da Transparência e área de gestão dos bolsistas.

Ao se obter a média mensal de gastos chegou-se ao valor médio total de $\mathrm{R} \$$ 141.598,06, que é gasto com as 21 pessoas que trabalham na CCONT com a instauração dos processos de TCE por mês.

$\mathrm{O}$ valor referente a férias e $13^{\circ}$ salário foi adicionado a média apurada, sendo adicionado 1/12, para que se chegue ao valor mensal custo de cada um desses itens. Para se atingir o valor mensal das férias foi dividido o valor da média dos últimos 6 meses por 3 , para se atingir o valor do terço de férias, e posteriormente dividido por 12 , para se 
alcançar o valor mensal. Para o cálculo do $13^{\circ}$ apenas se dividiu o valor da média dos últimos 6 meses por 12, representando valor a que o servidor tem direito de $13^{\circ}$ salário por mês.

Dentre os colaboradores, os únicos que recebem valores referente a férias e $13^{\circ}$ são os servidores, tendo em vista que o contrato com esses profissionais não prevê tais benefícios, diante da natureza das atividades especiais desenvolvidas por estes profissionais.

Tabela 3 - Colaboradores (valores em reais R\$)

\begin{tabular}{|c|c|c|c|c|}
\hline COLABORADORES & $\begin{array}{l}\text { MÉDIA DOS ULTIMOS } \\
6 \text { MESES (R\$) }\end{array}$ & $\begin{array}{l}\text { FÉRIAS } \\
(1 / 12)(\mathrm{R} \$)\end{array}$ & $\begin{array}{l}\text { 13 SALÁRIO } \\
(1 / 12)(\mathrm{R} \$)\end{array}$ & TOTAL (R\$) \\
\hline \multirow{14}{*}{$\begin{array}{l}\text { SERVIDORES E } \\
\text { CHEFIAS }\end{array}$} & $10.871,99$ & 302,00 & 906,00 & $12.079,99$ \\
\hline & $2.837,53$ & 472,92 & $1.418,77$ & $4.729,22$ \\
\hline & $3.861,98$ & 643,66 & $1.930,99$ & $6.436,63$ \\
\hline & $4.252,58$ & 708,76 & $2.126,29$ & $7.087,63$ \\
\hline & $4.281,15$ & 713,53 & $2.140,58$ & $7.135,25$ \\
\hline & $8.376,35$ & $1.396,06$ & $4.188,18$ & $13.960,58$ \\
\hline & $8.480,32$ & $1.413,39$ & $4.240,16$ & $14.133,86$ \\
\hline & $8.376,35$ & $1.396,06$ & $4.188,18$ & $13.960,58$ \\
\hline & $8.198,67$ & $1.366,45$ & $4.099,34$ & $13.664,45$ \\
\hline & $8.198,67$ & $1.366,45$ & $4.099,34$ & $13.664,45$ \\
\hline & $9.282,34$ & $1.547,06$ & $4.641,17$ & $15.470,57$ \\
\hline & $8.376,35$ & $1.396,06$ & $4.188,18$ & $13.960,58$ \\
\hline & $8.198,67$ & $1.366,45$ & $4.099,34$ & $13.664,45$ \\
\hline & $5.495,41$ & 915,90 & $2.747,71$ & $9.159,02$ \\
\hline \multirow{7}{*}{ BOLSISTAS } & $5.778,00$ & & & $5.778,00$ \\
\hline & $5.778,00$ & & & $5.778,00$ \\
\hline & $5.500,00$ & & & $5.500,00$ \\
\hline & $6.741,00$ & & & $6.741,00$ \\
\hline & $6.290,00$ & & & $6.290,00$ \\
\hline & $6.163,20$ & & & $6.163,20$ \\
\hline & $6.259,50$ & & & $6.259,50$ \\
\hline TOTAL & $141.598,06$ & $15.004,73$ & $45.014,18$ & 201.616,97 \\
\hline
\end{tabular}

Fonte: Elaborado pela autora. 
Os valores referentes a material de expediente não são totalmente conhecidos, tendo em vista a falta de controle dos valores do material solicitado, sendo esse dado obtido a partir de consulta a área, que informou esses valores como uma média de 6 meses.

Tabela 4 - Material de expediente (valores em reais $\mathrm{R} \$$ )

\begin{tabular}{|l|c|}
\hline \multicolumn{1}{|c|}{ MATERIAL } & MÉDIA para 1 mês \\
\hline Resmas de papel & $1.390,00$ \\
\hline Post-it & 50,00 \\
\hline Grampeador & 25,00 \\
\hline Cola & 10,00 \\
\hline Caneta & 20,00 \\
\hline Marca-texto & 30,00 \\
\hline TOTAL & $1.525,00$ \\
\hline
\end{tabular}

Fonte: Elaborado pela autora.

O material de expediente é composto basicamente de resmas de papel, canetas, tesoura, grampeadores, clipes, entre outros itens. A cada dois meses é solicitado material, sendo as resmas de papel como o item de maior valor nos pedidos.

\section{Serviços de terceiros}

Para obter o valor dos serviços de terceiros, a área forneceu o valor total do contrato para o período de janeiro a junho de 2016, tendo identificado 6 contratos (brigadistas, vigilância, carregador/estiva, copeira, garçom, etc.), sendo 1546484/000100 - Confederal Vigilância e Transporte de Valores; 26413146/0001-52 - CONFERE Comercio e Serviços de Alimentação; G\&E Serviços Terceirizados LTDA - EPP; 02843359/0001-56 - Planalto Service LTDA; 04281586/0001-60 - Utopia Consultoria e Assessoria LTDA - EP; e 01708458/0001-62 - Visão Administração e Construção LTDA. A área responsável pelos dados informou que é possível haver outros contratos, e que esses abrangem as 6 unidades do Ministério da Saúde em Brasília.

Para se chegar a média do valor gasto pela Coordenação de Contabilidade para execução de suas atividades e inclusive a instauração da TCE, foi dividido o valor total do período de janeiro e junho do ano de 2016 por 6, para se obter a média mensal para todas as unidades do MS em Brasília. Com a informação do valor mensal atribuído a 
todas as unidades no Ministério da Saúde, este valor foi dividido pela área total das 6 unidades no MS em Brasília, onde se chegou ao valor de $\mathrm{R}$ \$ 42,82 gasto com serviços de terceiros por $\mathrm{m}^{2}$, conforme detalhado na Tabela 4 .

Tabela 5 - Serviços de terceiros

\begin{tabular}{|l|r|}
\hline \multicolumn{1}{|c|}{ DESCRIÇÃO } & \multicolumn{1}{c|}{ VALORES } \\
\hline Valor Líquido do SIAFI operacional - Período de JAN a JUN de 2016. & $\mathrm{R} \$ 10.983 .601,54$ \\
\hline $\begin{array}{l}\text { Média mensal para todas as unidades do MS em Brasília (Valor líquido no } \\
\text { SIAFI dividido por 6 meses). }\end{array}$ & $\mathrm{R} \$ 1.830 .600,26$ \\
\hline $\begin{array}{l}\text { Proporção para atender a área da CCONT/FNS (total/ } 42.756 \mathrm{~m}^{2} \text { ) - valor } \\
\text { dos serviços de terceiros por m². }\end{array}$ & $\mathrm{R} \$ 42,82$ \\
\hline Valor total para atender a área da CCONT de $174,13 \mathrm{~m}^{2}$ por mês. & $\mathrm{R} \$ 7.455,38$ \\
\hline
\end{tabular}

Fonte: Elaborado pela autora.

Considerando que a área disponível para a execução das atividades da CCONT é de $174,13 \mathrm{~m}^{2}$, conforme medição realizada pela pesquisadora, atingiu-se o valor de $\mathrm{R} \$$ 7.455,38 de custo mensal para a CCONT referente a serviços de terceiros.

\section{Telefonia}

O serviço de telefonia utilizado pelos colaboradores da CCONT, exceto o das chefias, é compartilhado por grupo. Foi informado pelo Entrevistado 3 que consta dois contratos para prestar esse tipo de serviço nas seis unidades do Ministério da Saúde.

Então, para se chegar a média do valor gasto pela Coordenação de Contabilidade para execução de suas atividades e inclusive a instauração da TCE, foi dividido o valor total referente aos dois contratos do período de janeiro e junho do ano de 2016 por 6, para se obter a média mensal para todas as unidades do MS em Brasília. Com a informação do valor mensal atribuído a todas as unidades no Ministério da Saúde, este valor foi dividido pelo número total de postos de trabalho do MS em Brasília, onde se chegou ao valor de $\mathrm{R} \$ 38,65$, gastos com serviços telefonia por posto de trabalho no DF, conforme detalhado na Tabela 5.

Tabela 6 - Telefonia 


\begin{tabular}{|l|r|}
\hline Por mês para todos os prédios & $\mathrm{R} \$ 216.798,58$ \\
\hline Proporção para atender a uma pessoa (5610 postos de trabalho no DF) & $\mathrm{R} \$ 38,65$ \\
\hline Valor total para atender a 21 pessoas na Coordenação por mês & $\mathrm{R} \$ 811,55$ \\
\hline
\end{tabular}

Fonte: Elaborado pela autora.

Considerando que a quantidade de postos de trabalho para a execução das atividades da CCONT é de 21 colaboradores, atingiu-se o valor de R $\$ 811,55$ de custo mensal para a CCONT referente a serviços de telefonia.

O Entrevistado 3, que forneceu os dados, informa que é possível haver outros contratos, mas que a consulta retornou apenas os que foram apresentados.

Água

Para a apuração do valor referente a serviços de água, foi identificado apenas um contrato que abrange as 6 (seis) unidades do MS em Brasília/DF. Então, para se chegar a média do valor gasto pela CCONT/FNS, foi dividido o valor total do período de janeiro e junho do ano de 2016 por 6, para se obter a média mensal para todas as unidades do MS em Brasília. Com a informação do valor mensal atribuído a todas as unidades no MS, este valor foi dividido pela área total das 6 unidades no MS em Brasília, onde se chegou ao valor de $\mathrm{R} \$ 2,81$ gasto com serviço de fornecimento de água por $\mathrm{m}^{2}$, conforme detalhado na Tabela 6.

Tabela 7 - Água

\begin{tabular}{|l|r|}
\hline Valor Líquido do SIAFI operacional - Período de JAN a JUN de 2016 & $\mathrm{R} \$ 721.163,13$ \\
\hline Por mês para todos os prédios & $\mathrm{R} \$ 120.193,86$ \\
\hline Proporção para atender a área da CCONT/FNS (total/ $\left.42756 \mathrm{~m}^{2}\right)$ & $\mathrm{R} \$ 2,81$ \\
\hline Valor total para atender uma área da CCONT de $174,13 \mathrm{~m}^{2}$ & $\mathrm{R} \$ 489,51$ \\
\hline
\end{tabular}

Fonte: Elaborado pela autora.

Considerando que a área disponível para a execução das atividades da CCONT é de $174,13 \mathrm{~m}^{2}$, conforme medição realizada pela pesquisadora, atingiu-se o valor de $\mathrm{R} \$$ 489,51 de custo mensal para a CCONT referente a serviços de fornecimento de água.

\section{Energia Elétrica}


Para a apuração do valor referente a serviços de energia elétrica, foi identificado cinco contratos administrativos, separados por unidade. Neste caso foi considerado o Edifício Sede e o anexo como uma unidade. Além disso, foi levado em consideração o valor da conta, por que existem acréscimos como Taxa de Iluminação Pública e de bandeira tarifária, que devem ser incluídos além do kwH.

Portanto o cálculo foi semelhante ao realizado para o serviço de terceiro e serviço de fornecimento de água, foi dividido o valor total do período de janeiro e junho do ano de 2016 por 6, para se obter a média mensal para todas as unidades do MS em Brasília. Com a informação do valor mensal atribuído a todas as unidades no MS, este valor foi dividido pela área total das 6 unidades no MS em Brasília, onde se chegou ao valor de R $\$$ 28,62 gasto com serviço de fornecimento de energia elétrica por $\mathrm{m}^{2}$, conforme detalhado na Tabela 7 .

Tabela 8 - Energia elétrica

\begin{tabular}{|l|r|}
\hline Valor Líquido do SIAFI operacional - Período de JAN a JUN de 2016 & $\mathrm{R} \$ 3.917 .360,44$ \\
\hline Por mês para todos os prédios & $\mathrm{R} \$ 652.893,41$ \\
\hline Proporção para atender a área da CCONT/FNS (total/ $22816 \mathrm{~m}^{2}$ ) & $\mathrm{R} \$ 28,62$ \\
\hline Valor total para atender uma área da CCONT de $174,13 \mathrm{~m}^{2}$ & $\mathrm{R} \$ 4.982,83$ \\
\hline
\end{tabular}

Fonte: Elaborado pela autora.

Considerando que a área disponível para a execução das atividades da CCONT é de $174,13 \mathrm{~m}^{2}$, conforme medição realizada pela pesquisadora, atingiu-se o valor de $\mathrm{R} \$$ 4.982,83 de custo mensal para a CCONT referente a serviços de fornecimento de energia elétrica.

\section{Depreciação}

Em relação a aluguel e depreciação, o Entrevistado 3 apresentou o valor global, sem especificações, sendo considerado o valor gasto para as 6 unidades do MS em Brasília. Portanto, seguiu-se a mesma lógica de cálculo utilizado previamente para o cálculo prestação de serviços de terceiros, fornecimento de água e energia elétrica, em que foi dividido o valor total do período de janeiro e junho do ano de 2016 por 6, para se obter a média mensal para todas as unidades do MS em Brasília. Com a informação do valor 
mensal atribuído a todas as unidades no MS, este valor foi dividido pela área total das 6 unidades no MS em Brasília, onde se chegou ao valor de $\mathrm{R}$ \$39,58 gasto com depreciação e aluguéis por $\mathrm{m}^{2}$, conforme detalhado na Tabela 8 .

Tabela 9- Depreciação

\begin{tabular}{|l|r|}
\hline Valor Líquido do SIAFI operacional - Período de JAN a JUN de 2016 & $\mathrm{R} \$ 10.152 .616,99$ \\
\hline Por mês para todos os prédios & $\mathrm{R} \$ 1.692 .102,83$ \\
\hline Proporção para atender a área da CCONT/FNS (total/ $42756 \mathrm{~m}^{2}$ ) & $\mathrm{R} \$ 39,58$ \\
\hline Valor total para atender uma área da CCONT de $174,13 \mathrm{~m}^{2}$ & $\mathrm{R} \$ 6.891,33$ \\
\hline
\end{tabular}

Fonte: Elaborado pela autora.

Considerando que a área disponível para a execução das atividades da CCONT é de $174,13 \mathrm{~m}^{2}$, conforme medição realizada pela pesquisadora, atingiu-se o valor de $\mathrm{R} \$$ $6.891,33$ de custo mensal para a CCONT referente ao gasto com depreciação e aluguel.

\section{Considerações}

Existem outros objetos de custos que não foram possíveis mensurar, tendo em vista tratar-se de áreas extensas, que demandam a aplicação do modelo de custos de acordo com as suas atividades, e diante da falta de controle por parte da instituição, foram desconsiderados.

Essas áreas que foram desconsideradas na apuração abrange os custos com o setor de pessoal, alta gestão, o setor administrativo que processa e realiza o empenho, liquidação de todos os pagamentos, o setor de compras e os programas que são disponibilizados a todos os funcionários do Ministério da Saúde, tais como creches, cursos e programa de bem-estar (ginástica laboral). 


\section{APÊNDICE D - Categorias e subcategorias relacionadas ao SIC}

A análise de conteúdo das entrevistas relacionadas ao SIC gerou 21 subcategorias, que se agrupam em 3 diferentes categorias A Tabela 1 informa as categorias, apresentada em ordem de maior impacto, a subcategoria que se encontra vinculada, apresentada também em grau de maior impacto, a frequência com que cada subcategoria foi citada (podendo ter sido citada mais de uma vez pelo mesmo entrevistado), a quantidade de entrevistados que a mencionaram, com os respectivos percentuais, assim como o fator de impacto, obtido através da multiplicação entre a frequência e número de entrevistados que a citaram.

Tabela 1- Categorias e subcategorias relacionadas ao SIC

\begin{tabular}{|c|c|c|c|c|c|c|}
\hline \multirow{2}{*}{ CATEGORIA } & \multirow{2}{*}{ SUBCATEGORIAS } & \multicolumn{2}{|c|}{ FREQUÊNCIA } & \multicolumn{2}{|c|}{ ENTREVISTADOS } & \multirow{2}{*}{ IMPACTO } \\
\hline & & QNT & $\%$ & QNT & $\%$ & \\
\hline \multirow{10}{*}{ CARACTERÍSTICAS } & acesso ao sistema & 5 & $11,10 \%$ & 2 & $100,00 \%$ & 10 \\
\hline & integração & 5 & $11,10 \%$ & 2 & $100,00 \%$ & 10 \\
\hline & detalhamento & 4 & $8,90 \%$ & 2 & $100,00 \%$ & 8 \\
\hline & atualização dos dados & 3 & $6,70 \%$ & 2 & $100,00 \%$ & 6 \\
\hline & alterações & 2 & $4,40 \%$ & 2 & $100,00 \%$ & 4 \\
\hline & $\begin{array}{l}\text { processamento da } \\
\text { informação }\end{array}$ & 2 & $4,40 \%$ & 1 & $50,00 \%$ & 2 \\
\hline & dados suprimidos & 1 & $2,20 \%$ & 1 & $50,00 \%$ & 1 \\
\hline & estrutura do SIC & 1 & $2,20 \%$ & 1 & $50,00 \%$ & 1 \\
\hline & operacionalização & 1 & $2,20 \%$ & 1 & $50,00 \%$ & 1 \\
\hline & vantagens & 1 & $2,20 \%$ & 1 & $50,00 \%$ & 1 \\
\hline \multirow{5}{*}{$\begin{array}{l}\text { MÉTODO DE } \\
\text { CUSTEIO }\end{array}$} & custeio direto & 3 & $6,70 \%$ & 2 & $100,00 \%$ & 6 \\
\hline & requisito para o TDABC & 3 & $6,70 \%$ & 2 & $100,00 \%$ & 6 \\
\hline & adaptação & 2 & $4,40 \%$ & 2 & $100,00 \%$ & 4 \\
\hline & $\begin{array}{l}\text { limitação para o } \\
\text { TDABC }\end{array}$ & 2 & $4,40 \%$ & 1 & $50,00 \%$ & 2 \\
\hline & $\begin{array}{l}\text { refinamento da } \\
\text { informação }\end{array}$ & 2 & $4,40 \%$ & 1 & $50,00 \%$ & 2 \\
\hline \multirow{6}{*}{ PROBLEMAS } & problemas resolvidos & 3 & $6,70 \%$ & 1 & $50,00 \%$ & 3 \\
\hline & dados históricos & 1 & $2,20 \%$ & 1 & $50,00 \%$ & 1 \\
\hline & $\begin{array}{l}\text { divergência com os } \\
\text { sistemas estruturantes }\end{array}$ & 1 & $2,20 \%$ & 1 & $50,00 \%$ & 1 \\
\hline & $\begin{array}{l}\text { falta de organização no } \\
\text { órgão }\end{array}$ & 1 & $2,20 \%$ & 1 & $50,00 \%$ & 1 \\
\hline & instabilidade & 1 & $2,20 \%$ & 1 & $50,00 \%$ & 1 \\
\hline & manutenção & 1 & $2,20 \%$ & 1 & $50,00 \%$ & 1 \\
\hline
\end{tabular}




\section{APÊNDICE E - Categorias e subcategorias referente ao reembolso}

A análise de conteúdo das entrevistas referente a reembolso gerou 49 subcategorias, que se agrupam em 5 diferentes categorias. A Tabela 1 informa as categorias, apresentada em ordem de maior impacto, a subcategoria que se encontra vinculada, apresentada também em grau de maior impacto, a frequência com que cada subcategoria foi citada (podendo ter sido citada mais de uma vez pelo mesmo entrevistado), a quantidade de entrevistados que a mencionaram, com os respectivos percentuais, assim como o fator de impacto, obtido através da multiplicação entre a frequência e número de entrevistados que a citaram.

Tabela 1- Categorias e subcategorias referente ao reembolso

(Continua)

\begin{tabular}{|c|c|c|c|c|c|c|}
\hline \multirow{2}{*}{$\begin{array}{l}\text { CATEGO- } \\
\text { RIA }\end{array}$} & \multirow{2}{*}{ SUBCATEGORIA } & \multicolumn{2}{|c|}{ FREQUÊNCIA } & \multicolumn{2}{|c|}{ ENTREVISTADOS } & \multirow{2}{*}{$\begin{array}{c}\text { IM- } \\
\text { PACTO }\end{array}$} \\
\hline & & QNT & $\%$ & QNT & $\%$ & \\
\hline \multirow{12}{*}{$\begin{array}{l}\text { APURAÇÃO } \\
\text { DO CUSTO }\end{array}$} & $\begin{array}{l}\text { aspectos metodológicos da } \\
\text { apuração }\end{array}$ & 20 & $9,40 \%$ & 10 & $83,30 \%$ & 200 \\
\hline & elementos de composição do custo & 6 & $2,80 \%$ & 5 & $41,70 \%$ & 30 \\
\hline & apuração por meio do sistema & 4 & $1,90 \%$ & 4 & $33,30 \%$ & 16 \\
\hline & finalidade & 5 & $2,40 \%$ & 2 & $16,70 \%$ & 10 \\
\hline & dificuldade de apuração & 4 & $1,90 \%$ & 2 & $16,70 \%$ & 8 \\
\hline & valor razoável & 4 & $1,90 \%$ & 2 & $16,70 \%$ & 8 \\
\hline & transparência & 2 & $0,90 \%$ & 2 & $16,70 \%$ & 4 \\
\hline & validação da metodologia & 2 & $0,90 \%$ & 2 & $16,70 \%$ & 4 \\
\hline & distorções na apuração & 2 & $0,90 \%$ & 1 & $8,30 \%$ & 2 \\
\hline & áreas envolvidas & 1 & $0,50 \%$ & 1 & $8,30 \%$ & 1 \\
\hline & metodologia fácil e didática & 1 & $0,50 \%$ & 1 & $8,30 \%$ & 1 \\
\hline & normativo relevante & 1 & $0,50 \%$ & 1 & $8,30 \%$ & 1 \\
\hline \multirow{13}{*}{$\begin{array}{c}\text { COBRANÇA } \\
\text { DO CUSTO }\end{array}$} & pertinência da cobrança & 18 & $8,50 \%$ & 11 & $91,70 \%$ & 198 \\
\hline & normativo necessário & 15 & $7,10 \%$ & 11 & $91,70 \%$ & 165 \\
\hline & relevância em cobrar o custo & 5 & $2,40 \%$ & 5 & $41,70 \%$ & 25 \\
\hline & impertinência da cobrança & 9 & $4,20 \%$ & 2 & $16,70 \%$ & 18 \\
\hline & normativo insuficiente & 3 & $1,40 \%$ & 3 & $25,00 \%$ & 9 \\
\hline & atuação conjunta & 3 & $1,40 \%$ & 2 & $16,70 \%$ & 6 \\
\hline & proposta inédita & 3 & $1,40 \%$ & 2 & $16,70 \%$ & 6 \\
\hline & incerteza do recebimento do valor & 2 & $0,90 \%$ & 2 & $16,70 \%$ & 4 \\
\hline & normativo já existente & 2 & $0,90 \%$ & 1 & $8,30 \%$ & 2 \\
\hline & abrangência da cobrança do custo & 1 & $0,50 \%$ & 1 & $8,30 \%$ & 1 \\
\hline & diminuição do prejuízo & 1 & $0,50 \%$ & 1 & $8,30 \%$ & 1 \\
\hline & ideia utópica & 1 & $0,50 \%$ & 1 & $8,30 \%$ & 1 \\
\hline & pressupostos para cobrança & 1 & $0,50 \%$ & 1 & $8,30 \%$ & 1 \\
\hline
\end{tabular}


Tabela 1- Categorias e subcategorias referente ao reembolso

(Continua)

\begin{tabular}{|c|c|c|c|c|c|c|}
\hline \multirow{2}{*}{ CATEGORIA } & \multirow{2}{*}{ SUBCATEGORIA } & \multicolumn{2}{|c|}{ FREQUÊNCIA } & \multicolumn{2}{|c|}{ ENTREVISTADOS } & \multirow{2}{*}{ IMPACTO } \\
\hline & & QNT & $\%$ & QNT & $\%$ & \\
\hline \multirow{12}{*}{$\begin{array}{l}\text { QUESTIONA- } \\
\text { MENTOS } \\
\text { ADVERSOS }\end{array}$} & existência de & 15 & $7,10 \%$ & 11 & $91,70 \%$ & 165 \\
\hline & $\begin{array}{l}\text { questionamentos adversos } \\
\text { multa }\end{array}$ & 13 & $6,10 \%$ & 4 & $33,30 \%$ & 52 \\
\hline & atribuição da administração & 8 & $3,80 \%$ & 5 & $41,70 \%$ & 40 \\
\hline & $\begin{array}{l}\text { pública } \\
\text { falta de previsão legal para } \\
\text { cobrança }\end{array}$ & 6 & $2,80 \%$ & 5 & $41,70 \%$ & 30 \\
\hline & juros e atualização monetária & 5 & $2,40 \%$ & 3 & $25,00 \%$ & 15 \\
\hline & valor alto & 3 & $1,40 \%$ & 2 & $16,70 \%$ & 6 \\
\hline & cobrança além do dano & 2 & $0,90 \%$ & 2 & $16,70 \%$ & 4 \\
\hline & indagação dos responsáveis & 2 & $0,90 \%$ & 2 & $16,70 \%$ & 4 \\
\hline & encargo legal & 1 & $0,50 \%$ & 1 & $8,30 \%$ & 1 \\
\hline & $\begin{array}{l}\text { oposição das áreas de } \\
\text { controle }\end{array}$ & 1 & $0,50 \%$ & 1 & $8,30 \%$ & 1 \\
\hline & questionamentos jurídicos & 1 & $0,50 \%$ & 1 & $8,30 \%$ & 1 \\
\hline & valor arbitrário & 1 & $0,50 \%$ & 1 & $8,30 \%$ & 1 \\
\hline \multirow{9}{*}{$\begin{array}{l}\text { INSTAURA- } \\
\text { ÇÃO DA TCE }\end{array}$} & $\begin{array}{l}\text { adoção de medidas } \\
\text { administrativas }\end{array}$ & 14 & $6,60 \%$ & 5 & $41,70 \%$ & 70 \\
\hline & medida de exceção & 4 & $1,90 \%$ & 2 & $16,70 \%$ & 8 \\
\hline & falta de medidas & 3 & $1,40 \%$ & 2 & $16,70 \%$ & 6 \\
\hline & administrativas & 2 & $000 \%$ & 2 & $1670 \%$ & 1 \\
\hline & $\begin{array}{l}\text { tase externa } \\
.\end{array}$ & 2 & $0,90 \%$ & 2 & $16, / 0 \%$ & 4 \\
\hline & ineficiência da administração & 3 & $1,40 \%$ & 1 & $8,30 \%$ & 3 \\
\hline & morosidade na instauração & 3 & $1,40 \%$ & 1 & $8,30 \%$ & 3 \\
\hline & contradição entre os órgãos & 1 & $0,50 \%$ & 1 & $8,30 \%$ & 1 \\
\hline & mudança de concepção & 1 & $0,50 \%$ & 1 & $8,30 \%$ & 1 \\
\hline \multirow{4}{*}{$\begin{array}{c}\text { AÇÃO DE } \\
\text { COBRANÇA }\end{array}$} & improbidade & 2 & $0,90 \%$ & 1 & $8,30 \%$ & 2 \\
\hline & perda de direitos & 2 & $0,90 \%$ & 1 & $8,30 \%$ & 2 \\
\hline & perdas e danos & 2 & $0,90 \%$ & 1 & $8,30 \%$ & 2 \\
\hline & bloqueio de bens & 1 & $0,50 \%$ & 1 & $8,30 \%$ & 1 \\
\hline
\end{tabular}

Fonte: Elaborado pela autora. 
APÊNDICE F - Expediente de encaminhamento de sugestão

(Sua cidade) $\quad, \quad$ de $\quad$ de 2008

Exmoำ $\left.{ }^{-}\right)$Senhor(a)

Deputado(a)

Presidente da Comissão de Legislação Participativa

Câmara dos Deputados

Dirijo-me a V. Exa. para encaminhar, a título de sugestão de iniciativa legislativa, texto elaborado pela (nome da entidade) (sigla da entidade, caso tenha) que dispõe sobre a apuração e o reembolso para Administração Pública do custo do processo de Tomada de Contas Especial

(é recomendável preencher este espaço com a EMENTA da sugestão, isto é, resumo claro, fiel e conciso do conteúdo da proposta).

Colocamos nossa entidade à disposição desse Colegiado para o debate do assunto.

Atenciosamente,

Nome do representante

Cargo 


\section{SUGESTÃO}

ASSUNTO: Apuração e reembolso do custo do processo de Tomada de Contas Especial

\section{TEXTO DA SUGESTÃO:}

Dispõe sobre a apuração e o reembolso para Administração

Pública do custo do processo de Tomada de Contas Especial

O Congresso Nacional decreta:

Art. 1․ O custo do processo de Tomada de Contas Especial será cobrado aos responsáveis que ensejaram o início do processo, de acordo com as normas estabelecidas nesta Lei.

Parágrafo único. Caso seja extinta a responsabilidade, o custo do processo não será cobrado, sendo esses gastos absorvidos pela União.

Art. $2^{\circ}$. O pagamento do custo do processo é feito mediante a guia de recolhimento da união - GRU - utilizando código de recolhimento específico.

Art. 3‥ Incumbe ao órgão instaurador, quando o processo ainda estiver na fase interna, ou ao órgão julgador, quando o processo estiver na fase externa, fiscalizar e acompanhar o valor e o exato recolhimento desse custo.

Parágrafo único. Para efeito do disposto neste artigo, consideram-se como fase interna todos os procedimentos adotados anteriores à entrada dos autos no Tribunal de Contas da União, e fase externa a partir do ingresso do processo no Tribunal de Contas da União.

Art. 4․ O valor do custo do processo abrangerá desde 0 início do processo na fase interna até o final do julgamento na fase externa.

Art. 5․ São isentos do pagamento desse custo a União, os Estados, os Municípios, os Territórios Federais, o Distrito Federal e as respectivas autarquias e fundações.

Art. 6 Cada órgão nomeará uma comissão para realizar a 
validação da metodologia de apuração e o acompanhamento para implementação.

Art. 7‥ Após o julgamento do processo, se a parte responsável pelo custo, devidamente intimada, não as pagar dentro de quinze dias, a Procuradoria Geral da União deverá ser acionada pelo órgão julgador, para adotar os procedimentos para a inscrição como dívida ativa da União.

Art. 8ํ․ Esta lei entra em vigor na data da sua publicação

JUSTIFICAÇÃO: A inexistência do meio de apuração desses custos é um dos fatores impeditivos para que exista a imputação desses gastos a quem thes deu causa. $\mathrm{Na}$ atual situação, os gastos com o processamento das TCEs são absorvidos pelo erário, em lugar de integrarem os danos a serem ressarcidos mediante devido processo legal. 